\title{
IMPACT OF BUILDING INTEGRATED PHOTOVOLTAICS (BIPV) \\ IN ARCHITECTURAL SCIENCE BUILDING (ARC) \\ RYERSON UNIVERSITY
}

\section{By}

\section{Amit Gurung}

Bachelor of Architecture

Tribhuwan University, 2004

\begin{abstract}
An MRP
presented to Ryerson University

in partial fulfillment of the

requirements for the degree of

Master of Building Science

in the Department of Architectural Sciences
\end{abstract}

Toronto, Ontario, Canada, 2017

CAmit Gurung, 2017 


\section{Author's Declaration}

I hereby declare that I am the sole author of this MRP. This is a true copy of the MRP, including any required final revisions. I authorize Ryerson University to lend this MRP to other institutions or individuals for the purpose of scholarly research.

I further authorize Ryerson University to reproduce this MRP by photocopying or by other means, in total or in part, at the request of other institutions or individuals for the purpose of scholarly research.

I understand that my MRP may be made electronically available to the public. 
Impact of Building Integrated Photovoltaics (BIPV) in Architectural Science Building (ARC), Ryerson University, Amit Gurung, Masters in Building Science (M.BSc), Ryerson University, 2017

\section{Abstract}

Solar heat gains, heating, cooling and lighting energy demands are the primary energy associated with building operation. Glare and solar heat gains are the common issues in the buildings with high window to wall ratio. Window blinds are commonly used to control the glare which blocks the natural lights as well. Scientifically designed external shading devise also helps to control glare which are merely used in the tall modern glass buildings. So renewable technologies like Building Integrated Photovoltaics (BIPV) can be one of the strategies to address the primary energy demand of the building, glare control as well as on site electricity generation. The study includes the performance of BIPV application in the faculty office area of third floor of ARC building at Ryerson University. It shows that the BIPV can be effective by addressing the lighting, cooling demand effectively. 


\section{Acknowledgements}

First of all, I would like to thank Prof. Ramakrishnan, MRP supervisor, for his guidance throughout this process. The daylighting lectures have widened my knowledge and horizon to integrate architecture and building science.

My sincere thanks and gratitude goes to Prof. Doshi for his hands on guidance during the Research Methodology lectures. I conceived the MRP topic during his lectures and was able to develop the primary framework of research proposal under his guidance.

I would also like to convey thanks to Prof. Violeta for responding to my questions and providing me with some of the important information about the research paper.

I would also like to thank Prof. Berardi for providing the building science theory knowledge, a very important base in building science. Also would like to thank him for the critical feedback on my research proposal.

Special thanks to Mimi for her constant support and help in the administrative matters.

Most importantly, I would like to thank my wife Sita, daughters Sarhana and Samridhi for being the reason to smile. Without their love and affection, the building science study would be just impossible. 


\section{Table of Contents:}

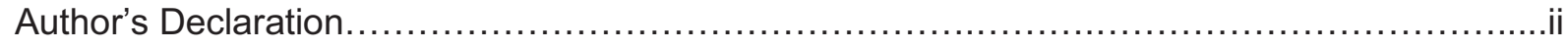

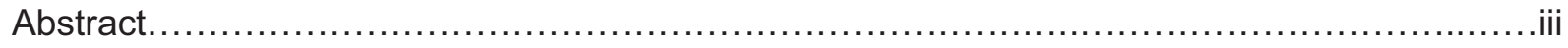

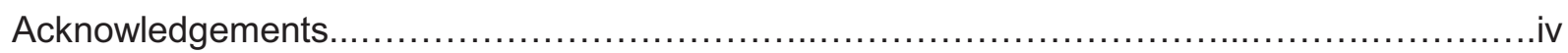

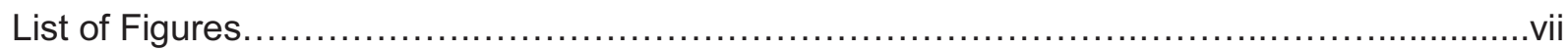

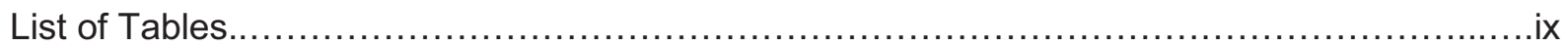

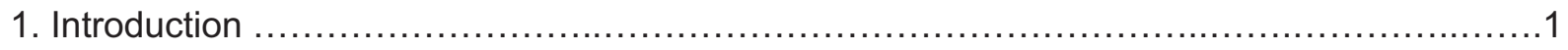

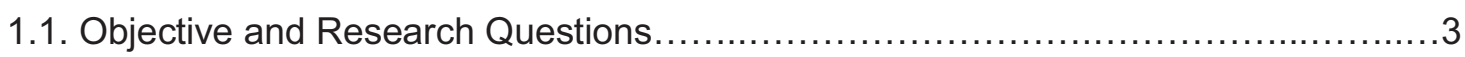

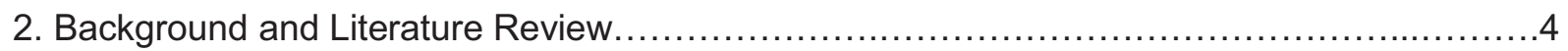

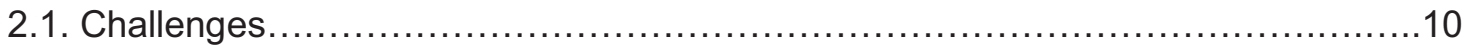

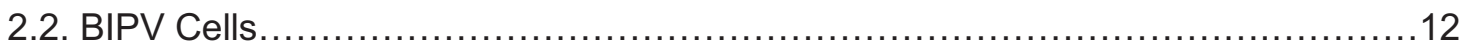

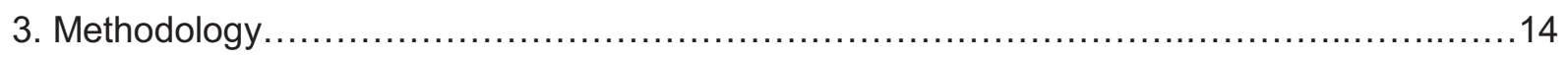

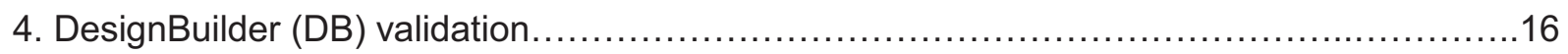

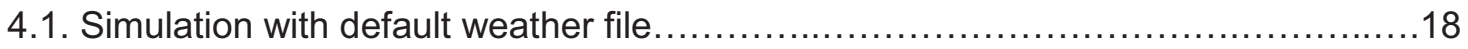

4.1.1. Solar heat gains with default weather file.................................19

4.1.2. Heating, Cooling and Lighting Energy Demand (default weather file).....20

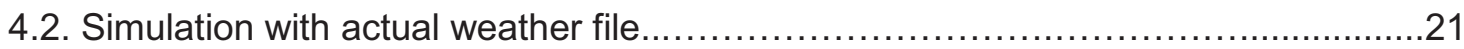

4.2.1. Solar heat gains with actual weather file.................................22

4.2.2. Heating, Cooling and Lighting Energy Demand (actual weather file)......22

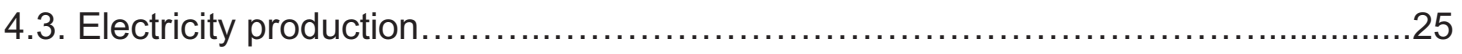

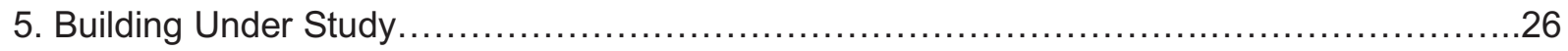

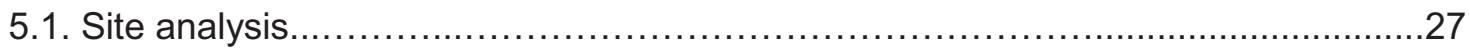

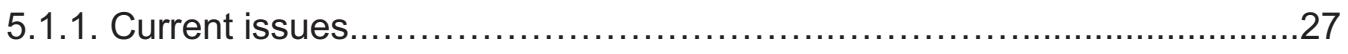

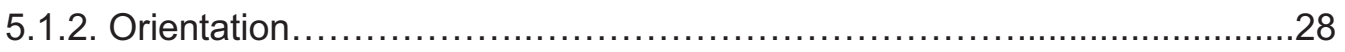

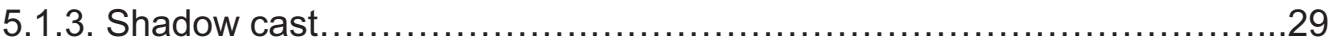

5.1.4. Window to wall (WWR) ratio analysis.................................... 32

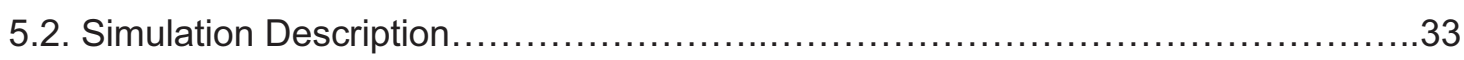


5.3. Results of base model and comparison.

5.4. Third floor office area.

5.5. Results of BIPV application. 36

5.5.1. Case 1: Full BIPV on South and West...............................36

5.5.1.1. Electricity Generation.........................................38

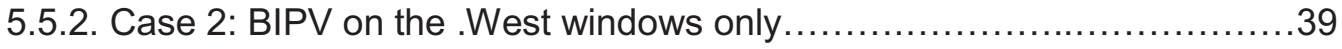

5.5.2.1. Electricity Generation.........................................41

5.5.3. Case 3: BIPV on the lower half of West windows only $\ldots \ldots \ldots \ldots \ldots \ldots \ldots 42$

5.5.3.1. Electricity Generation..........................................44

5.5.4. Case 4: BIPV + Lo-E on South and Wes windows........................45

5.5.4.1. Electricity Generation..................................... 48

5.5.5. Case 5: BIPV on the lower half of the South and West windows............49

5.5.5.1. Electricity Generation.......................................50

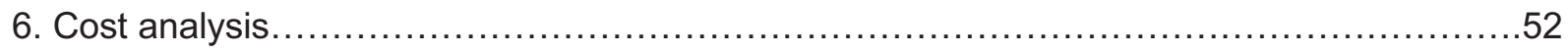

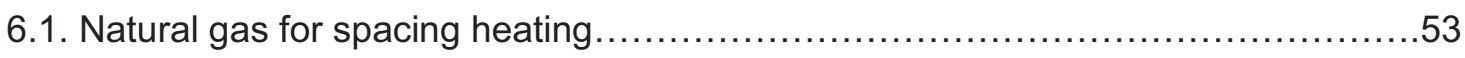

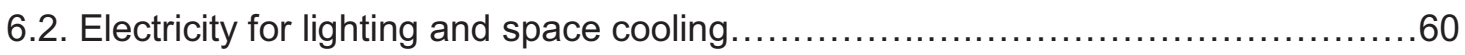

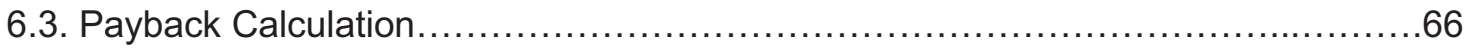

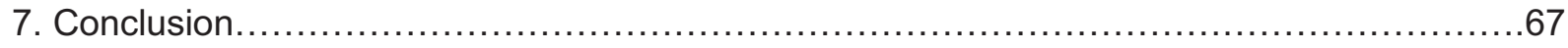

\section{References}




\section{List of Figures:}

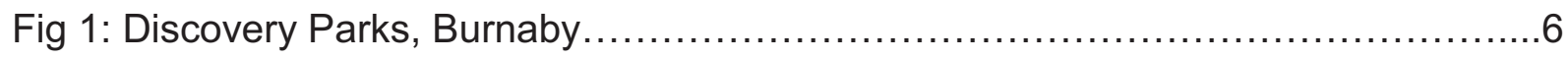

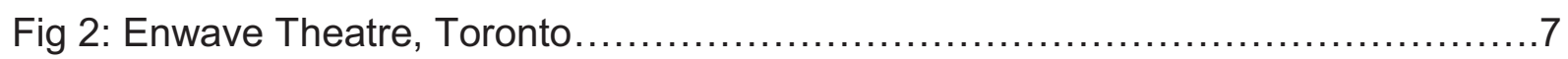

Fig 3: Application of BIPV in European countries. .................................. 11

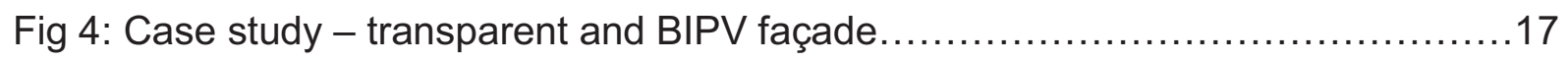

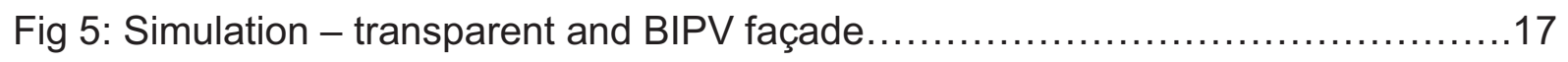

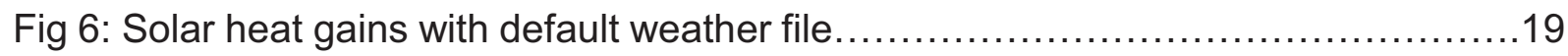

Fig 7: Heating, Cooling and Lighting energy demand comparison (default weather

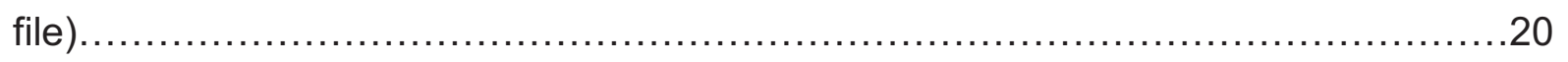

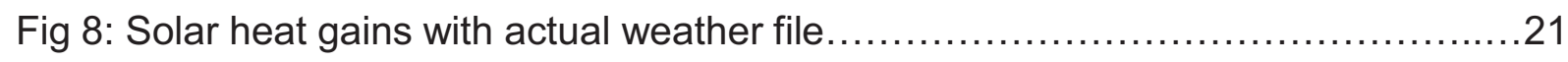

Fig 9: Heating, Cooling and Lighting energy demand comparison (actual weather

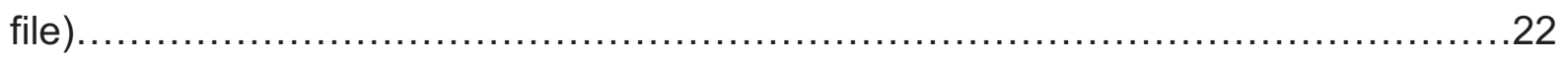

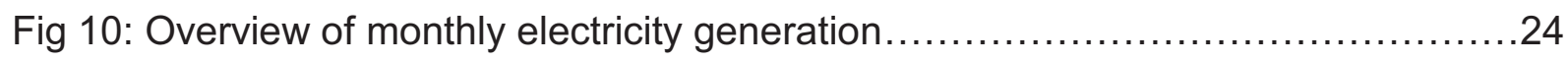

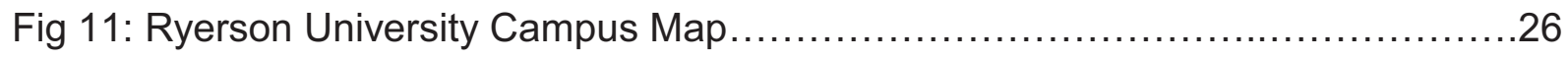

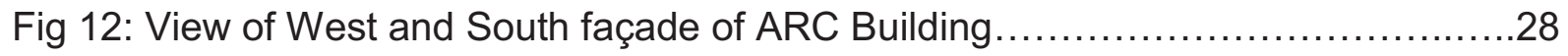

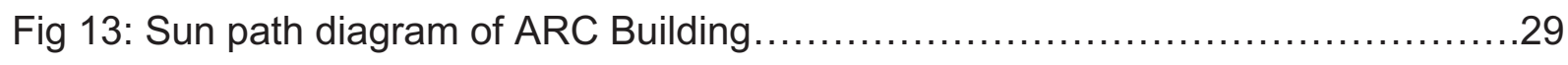

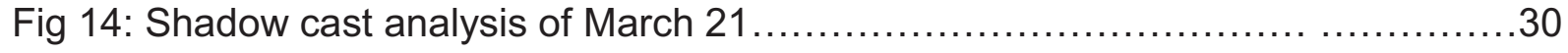

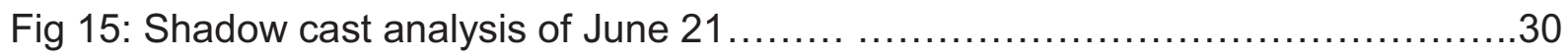

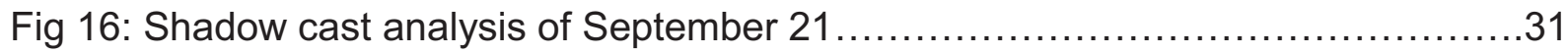

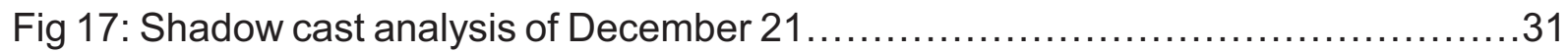

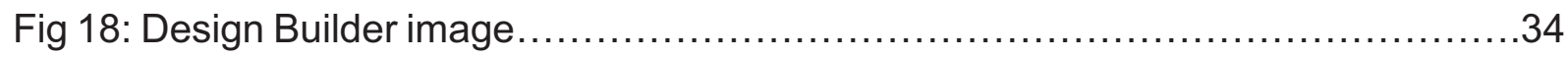

Fig 19: Case 1 vs Base Model - Monthly Solar Heat Gains $\left(\mathrm{kWh} / \mathrm{m}^{2}\right) \ldots \ldots \ldots \ldots \ldots \ldots \ldots$

Fig 20: Case 1 vs Base Model - Monthly Heating, Cooling, Lighting Energy

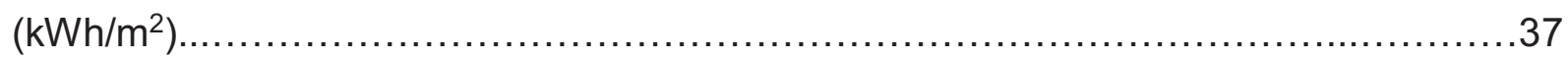




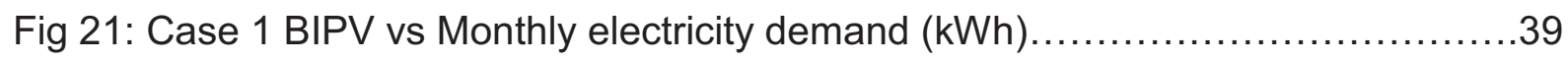

Fig 22: Case 2 vs Base Model - Monthly Solar Heat Gains $\left(\mathrm{kWh} / \mathrm{m}^{2}\right) \ldots \ldots \ldots \ldots \ldots \ldots . \ldots 39$

Fig 23: Case 2 vs Base Model - Monthly Heating, Cooling, Lighting Energy

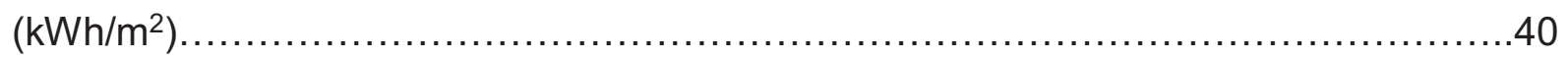

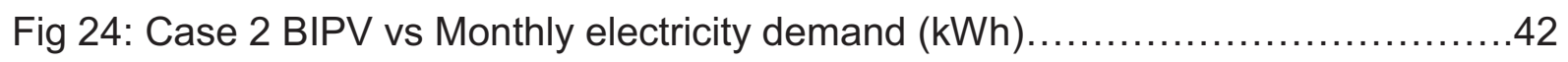

Fig 25: Case 3 vs Base Model - Monthly Solar Heat Gains $\left(\mathrm{kWh} / \mathrm{m}^{2}\right) \ldots \ldots \ldots \ldots \ldots \ldots . \ldots 43$

Fig 26: Case 3 vs Base Model - Monthly Heating, Cooling, Lighting Energy

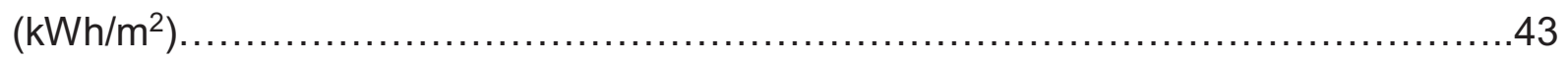

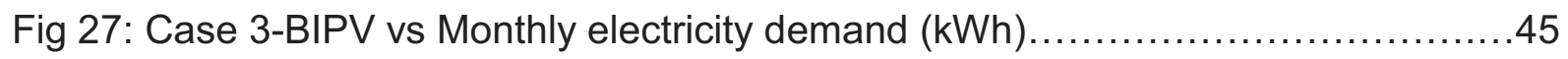

Fig 28: Case 4 vs Base Model - Monthly Solar Heat Gains $\left(\mathrm{kWh} / \mathrm{m}^{2}\right) \ldots \ldots \ldots \ldots \ldots \ldots \ldots$

Fig 29: Case 4 vs Base Model - Monthly Heating, Cooling, Lighting Energy

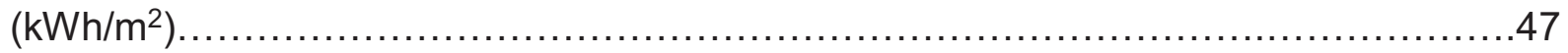

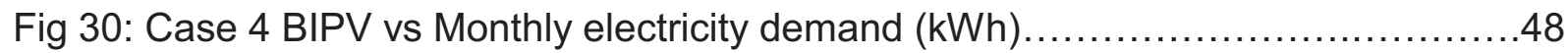

Fig 31: Case 5 vs Base Model - Monthly Solar Heat Gains $\left(\mathrm{kWh} / \mathrm{m}^{2}\right) \ldots \ldots \ldots \ldots \ldots \ldots . \ldots 49$

Fig 32: Case 5 vs Base Model - Monthly Heating, Cooling, Lighting Energy

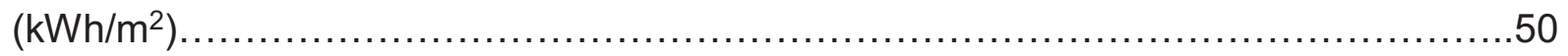

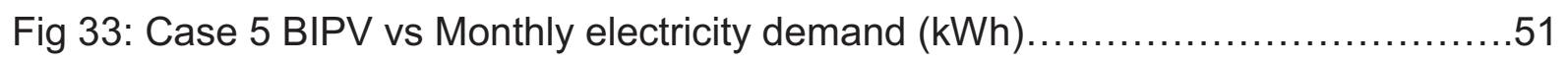

Fig 34: Annual cost of electricity for cooling and lighting vs BIPV (pricing in dollars)...60 


\section{List of Tables:}

Table 1: European countries and BIPV support policy types........................

Table 2: Summary of BIPV details from literature review............................

Table 3: Annual solar heat gains comparison $\left(\mathrm{kWh} / \mathrm{m}^{2}\right)$ with default weather file........19

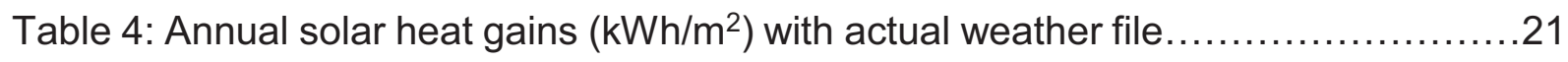

Table 5: Comparison between monitored and simulated BIPV electricity ...............24

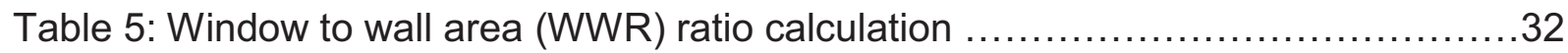

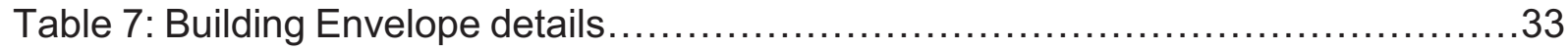

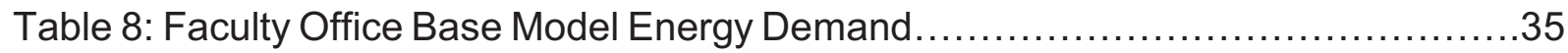

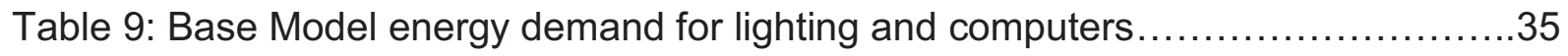

Table 10: Case 1-Monthly Heating, Cooling, Lighting and Heat Gains...................37

Table 11: Case 1-BIPV electricity vs lighting and computer electricity demand ...........38

Table 12: Case 2-Monthly Heating, Cooling, Lighting and Heat Gains $\left(\mathrm{kWh} / \mathrm{m}^{2}\right) \ldots \ldots . .41$

Table 13: Case 2-BIPV electricity vs lighting and computer electricity demand..........41

Table 14: Case 3- Monthly Heating, Cooling, Lighting and Heat Gains $\left(\mathrm{kWh} / \mathrm{m}^{2}\right) \ldots \ldots . .44$

Table 15: Case 3-BIPV electricity vs lighting and computer electricity demand..........44

Table 16: Case 4- Monthly Heating, Cooling, Lighting and Heat Gains $\left(\mathrm{kWh} / \mathrm{m}^{2}\right) \ldots \ldots . .47$

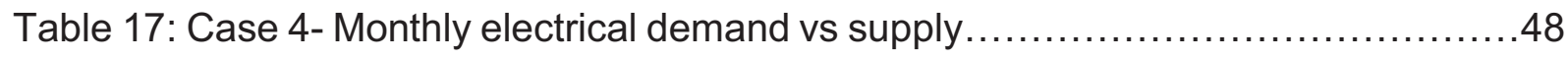

Table 18: Case 5-Monthly Heating, Cooling, Lighting and Heat Gains $\left(\mathrm{kWh} / \mathrm{m}^{2}\right) \ldots \ldots . .50$

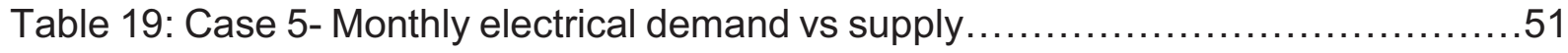

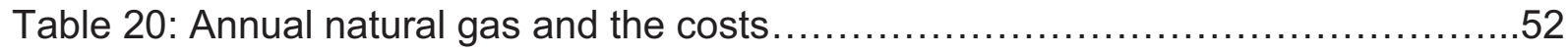

Table 21: Base Model-Cost of lighting, cooling and computers.......................53

Table 22: Case1-Cost of lighting, cooling and computers vs BIPV Revenue..............54

Table 23: Case 2-Cost of lighting, cooling and computers vs BIPV Revenue............56 
Table 24: Case3- Cost of lighting, cooling and computers vs BIPV Revenue .............57

Table 25: Case4-Cost of lighting, cooling and computers vs BIPV Revenue..............58

Table 26: Case5-Cost of lighting, cooling and computers + BIPV Revenue..............59

Table 27: Summary of Annual energy cost vs BIPV Revenue........................59

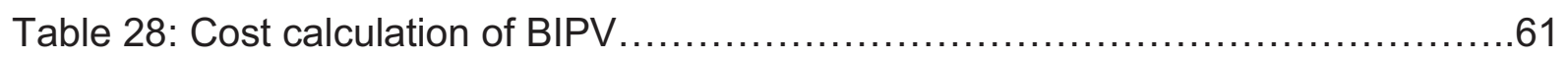

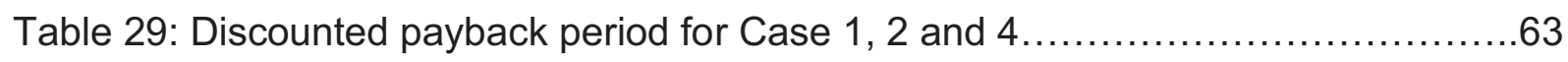

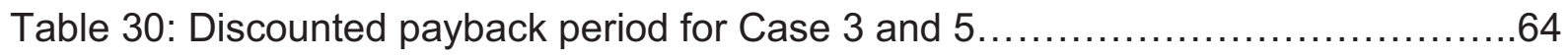




\section{Introduction}

General understanding of the Photovoltaic (PV) technology is that converts the solar energy into electricity. The most commonly known application for PV is roof/ground mounted. These methods are practiced globally and considered as the common photovoltaic technology. During the early stage, PV technology was mostly used to supply power to the buildings in the remote areas only. Due to the escalating energy price, environmental concern and local/ regional policies, the application of PV technology increased. Over the years, different ways of photovoltaic installation have been adopted. They are categorized as; ground mounted, Building Attached Photovoltaics (BAPV) and Building Integrated Photovoltaics (BIPV).

Compared to the conventional PV technology, BIPV is considered younger technology but the advantages can be measured from multidimensional aspects. The beauty of BIPV is that it serves dual purposes; it replaces the building envelope and generates electricity at the same time. So, BIPV becomes an integral part of the building envelope system and contributes to the overall performance. For example, BIPV can performs as a building envelope by replacing curtain/window wall or glazed roof and also generates energy on site. So, the energy generated by BIPV will have less environmental impacts as well as reduced loss factor compared to grid supply. With the development in the technology, the performance of BIPV have been analyzed in different climatic zones such as hot-humid in Hong Kong to cold European countries. Studies have shown that the building can benefit by the appropriate application of BIPV. Combination of appropriate daylight study and BIPV application can be advantageous by creating the visual comfort that minimises 
extra cost of window blinds or shading devise. So, the other benefits of BIPV can be effective tool to control glare which also reduces the solar heat gains and the cooling energy demand. This practice can be useful in the major reduction of the primary energy demand as well as the carbon footprint of the building. The BIPV can also contribute to the net zero energy or passive house design concept. So, including BIPV at the early stage of design inception plays important role in the power generation and defining the architectural volume of the building.

Despite all the potential advantages, the BIPV is still lags far behind the conventional PV technology. One of the major reasons is the cost, which is considered much higher than the ground/roof mounted and BAVP technologies. The other reasons are the lack of public awareness, missing of supporting policies and knowledge gap among the professionals. Similarly, the maintenance and performance aspects needs to be simplified during the design and application stage. In some parts of the world, the technology is still in the development and experimental phase. It takes time for public to gain confidence with the application. Because it is an envelope system of the building and any critical issue can be fatal for mass dissemination. However, countries like France and Italy have proven that the BIPV can be implemented with supporting policy. Some other European countries are also introducing the BIPV supporting policies. So, it can be concluded that the future of BIPV is optimistic. The traditional image of building as a major energy consumer can be transformed into energy generator with the use of BIPV. The technology can offer alternative envelope solution to the future architecture. 


\subsection{Objective and Research Questions}

The purpose of this study is to determine if the application of BIPV in Architectural Science Building (ARC) Ryerson proves to be advantageous in terms of building energy performance. For this investigation, simulation will be done using DesignBuilder software. The performance analysis will focus on the annual heating, cooling and lighting demand before and after the application of BIPV. To understand the economic feasibility, cost analysis will be done. The cost break down can be useful to analyse the financial aspects and will be compared with a typical conventional windows that are currently in use. The study will try to investigate better explanation for the following research questions.

- How does it impact the heating and cooling energy demand?

- How does it affect the daylighting performance?

- How much of electricity can be generated by BIPV systems? 


\section{Background and Literature Review}

Glass is a common building material. It's been widely used in high rise buildings all over the world due to its visual appeal, lightweight (compared to brick or stone) and possibility of faster installation. The glittering glass buildings have become a common practice for high rise construction eventually representing symbol of modern architecture around the world. As a result, commercial buildings, office towers or high rise residential condominiums have been extensively using glass as building envelope. Despite visual appeal and faster installation advantages, the solar heat gain, and poor temperature (heat and cold) balance are the major drawbacks. This adds heating or cooling load for conditioning the space affecting operating cost and increase in greenhouse gas emission as well. Glare and visual discomfort are the associated issues. Lighting shelves or window blinds have been most common practice to resolve the discomfort due to glare and relying on the artificial lighting.

Due to the growing demand for clean energy source, the use of solar photovoltaic technology has increased. According to European Photovoltaic Industry Association (EPIA) report, 2014, at least 38.4 GW of photovoltaic (PV) systems were installed globally in 2013, which was $30 \mathrm{GW}$ in 2012 [1]. PV remains, after hydro and wind power, the third most important renewable energy source in terms of globally installed capacity. Similarly, International Energy Agency reports that Canada's total PV power installed capacity almost doubled from 281.13 MW in 2010 to $558.74 \mathrm{MW}$ in 2011 [2]. To benefit from the natural source of energy, PV technologies have been used as a reliable source to produce electricity. Unlike the most commonly used PV technologies like roof/ground mounted that 
are independent, BIPV is used as an integral part of the building envelope. There are many applications and types of BIPV, such as roofing tiles and spandrel panels, semitransparent BIPV panels for glazed envelopes which provides design option for architects. Apart from producing clean electricity, a well-designed BIPV can play significant role to enhance daylighting.

The major objective of this study is to analyse the scope and challenges while using BIPV for optimizing daylighting control and electricity production. The research is focused on the retrofitting the existing building with BIPV to analyse its impact on annual heating and cooling energy demand as well as daylighting. The solar energy resource in Canada is characterized by seasonal variations [3]. Due to this typical characteristic, grid tied PV system proves to be efficient as the storage battery is not required and the energy generated can be averaged over the year. Using BIPV partially reduces the overall cost of solar electricity and also provides other benefits such as: acoustic and thermal insulation, weather proofing, aesthetics, daylighting, shading and privacy. Despite its potential, the author considers that BIPV projects in Canada in experimental stage creating awareness among professionals, stake holders and public about opportunities and limitations. By using semi-transparent and opaque silicon thin film modules on the curtain walls façade in a Discovery Parks, Burnaby [Fig.1], a balance between daylighting and power generation was achieved. The glass façade, overlooking the entrance of the building, has $3.5 \mathrm{~kW}$ PV array integrated. 
From the semi-transparent PV modules transmission of $30 \%$ incident light occurs which controls the glare and maintains privacy to the interior. Some of the major reasons for BIPV not being widely used in Canada are;

- the low cost of electricity,

- need of implementation of complimentary programs such as net metering,

- certification of equipment and the skilled personnel

- acceptance by customers

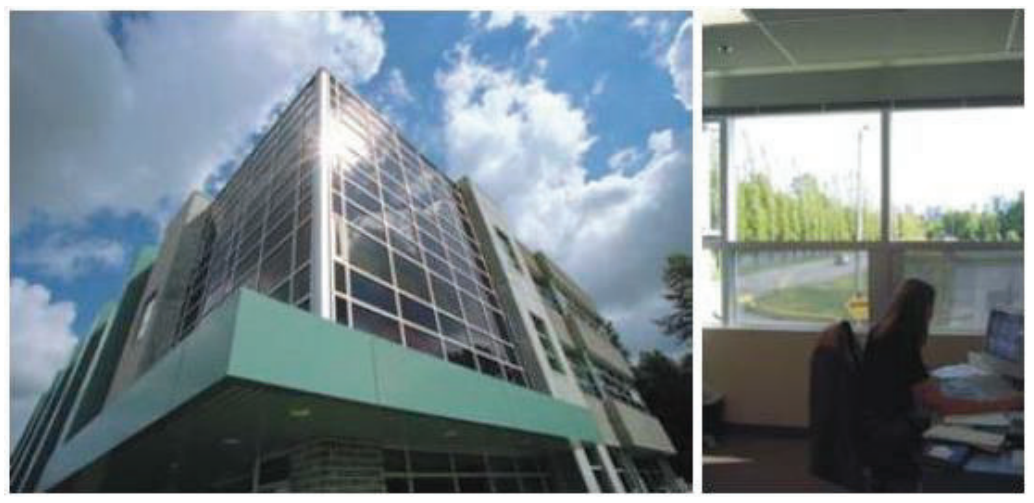

Fig 1: Discovery Parks, Burnaby [3]

A huge potential of BIPV in Canada is highlighted in a report [4] suggesting that the $46 \%$ of Canada's residential electricity needs could be supplied by BIPV systems. Or the combined residential and commercial/institutional Canadian building stock, which consume $29 \%$ of the 246 Terawatt-hour annually demand could be supplied by PV avoiding the associated 23 mega tonnes of greenhouse gas emissions [4]. The research was focused on the residential (single detached, attached, mobile homes), commercial/ institutional and municipalities (Calgary-Alberta, Saskatoon-Saskatchewan, WhatiNorthwest Territories) buildings in Canada and the provinces. Compared to industrial buildings, the residential and commercial/ institutional sector have less electricity intensity, indicating BIPV being more suitable to the later sectors. 
Internat Energy Solution Canada published a report [5] about the application of BIPV in Enwave Theatre at Harbourfront Centre, Toronto in 2010. The small portion on the west side of slope glass roof was chosen for the experimental BIPV application. The actual electricity production for the year 2012 was recorded to be $1,451 \mathrm{kWh}$, which matched closely with the modeled results. Software like DesignBuilder and PVsyst were used for analysis and modelling. Fig 2 shows the BIPV application on the glazed slope roof of Enwave Theatre.
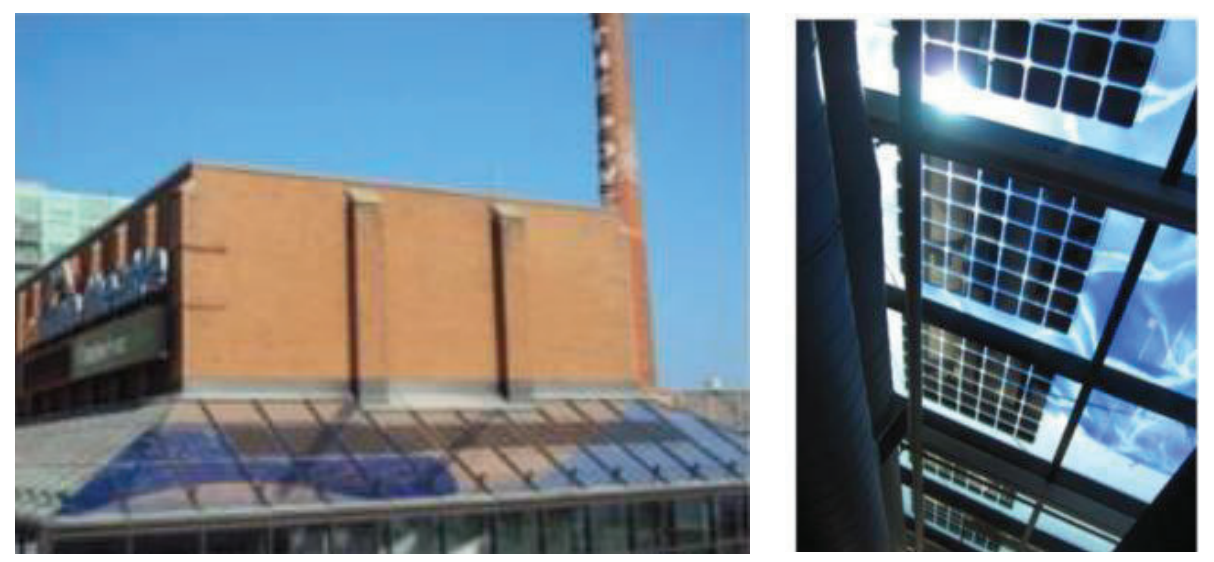

Fig 2: Enwave Theatre, Toronto [5]

A comparative study, before and after BIPV application, shows the difference in the relative humidity and temperature performance. The study shows that before BIPV application, the maximum interior temperature in September is as high as $39^{\circ} \mathrm{C}$ and the relative humidity is more than $60 \%$. But after BIPV application the maximum relative humidity recorded in the August is $55 \%$ and the temperature recorded is $32^{\circ} \mathrm{C}$. This shows that the interior temperature and the relative humidity improved after the application of BIPV. Due to the application of BIPV in the Enwave Theatre, 567 tonnes of $\mathrm{CO}_{2}$ is expected to be reduced over the next 30 years. 
The actual energy performance does not only depend on power conversion efficiency criteria of solar cell [6]. It is also affected by structure of cell, fabrication methods and solar absorptance. Other parameters like building location, thermal-optical character of window system, fuel type (natural gas/electricity), fuel cost and environment impact also plays vital role during the evaluation process of BIPV.

A simulation based research of double pane ventilated PV window for office space was conducted in Hong Kong [7]. The result shows the solar radiation, on the vertical surface of south side is lower during summer and highest in winter. Also the southwest vertical face experiences the highest annual solar radiation compared to the typical south or south east orientations. It concludes the solar cells with transmittance between $0.45-0.55$, electricity (energy saving) for air conditioning and lighting reduces.

On a double pane window with semi-transparent solar cell shows the positive impact on the thermal loads, daylighting utilization and electricity generation [8]. The parametric analysis of $50 \%$ window wall ratio (WWR) and $40 \%$ solar transmittance shows the $54 \%$ energy saving compared to standard model.

The field based study of BIPV (as shading device) in Korea shows that the cell efficiency is highly influenced by the surface temperature and the shadow cast [9]. During summer (June) the cell surface temperature goes higher causing less electricity production and vice versa during winter. Also high sun angles during summer causes shadow cast on BIPV shading devices below that also negatively impacts the performance. 
An experimental study in Hong Kong shows that when BIPV is used as a part of double skin façade, the heat gain and heat loss reduces besides generating electricity [10]. It was observed that the ventilated double skin façade has low solar heat gain coefficient and non-ventilated reduces heat loss that ultimately reduces the air - conditioning load in hot tropical climates.

Three major benefits of BIPV over centralized grid connected PV systems [11], are:

- When PV panels are installed in the structure of the building, the costs of land and structures to maintain the panels are avoided;

- Because BIPV systems produces electricity near the point of use, losses associated with the transmission and distribution of the electricity are avoided. This represents an important aspect of commercial buildings, where the time of highest power demand coincides with the time of electricity supply from the PV panels;

- The PV panels of a BIPV system can be used as important components of the building's facades or roofs, thus reducing materials' costs.

A research in Egypt suggests a very useful method to identify (select) the best envelope shape for highest solar exposure [12]. The study says the shape of building, orientation and position plays important role for better outcome. And further demonstrates how the shape of existing buildings can be transformed to maximize the solar exposure for higher productivity. 
International Energy Agency in report Task 41.B.3 [13] have documented the present tools that can be a guidance to architects for using in the solar architecture projects. Having an access and understanding of these tools can benefit architects from the early stage of design development. For the successful application of BIPV, importance of architectural and solar suitability have been briefly explained in report IEA - PVPS T7-4: 2002 [14]. It says architectural suitability should consider historical aspects, shading effects, construction limitations while the solar suitability concentrates on the amount of solar radiation on the surface, orientation, inclination and the site's geographical location.

\subsection{Challenges}

Despite the huge potential of BIPV power generation, it is still far behind the expected level of wider dissemination and application. The factors that are creating market resistance of BIPV are [15];

- High initial investment capital costs and

- Lack of government policy support and incentives

- Methods for BIPV cost-benefit analysis not in place

- Limited studies risk factors/barriers of BIPV from a supply chain perspective

- Missing strategies to connect industry and academics to encourage BIPV diffusion and application 
Figure 3 shows the application of BIPV compared to ground mounted or BAPV in four European countries. The policy has been a driving factor behind the successful application or elimination of technologies. For example, Germany is considered as one of the leading countries in solar technologies where the BAPV application is the highest $(82 \%)$ of the PV market in Germany. Traditional ground mounted technology occupies the $17 \%$ of the market share while the BIPV application is the least $(1 \%)$. In Spain also, the market share of BIPV is very low compared to the ground mounted PV technology that holds the market share of $75 \%$ followed by BAPV with $23 \%$. In Italian scenario, the market share of BIPV, BAPV and ground mounted technology is evenly distributed. Whereas in France, BIPV application is highest among the four countries. The market share of BIPV is $59 \%$ followed by ground mounted which is $30 \%$ and the least $11 \%$ is BAPV.

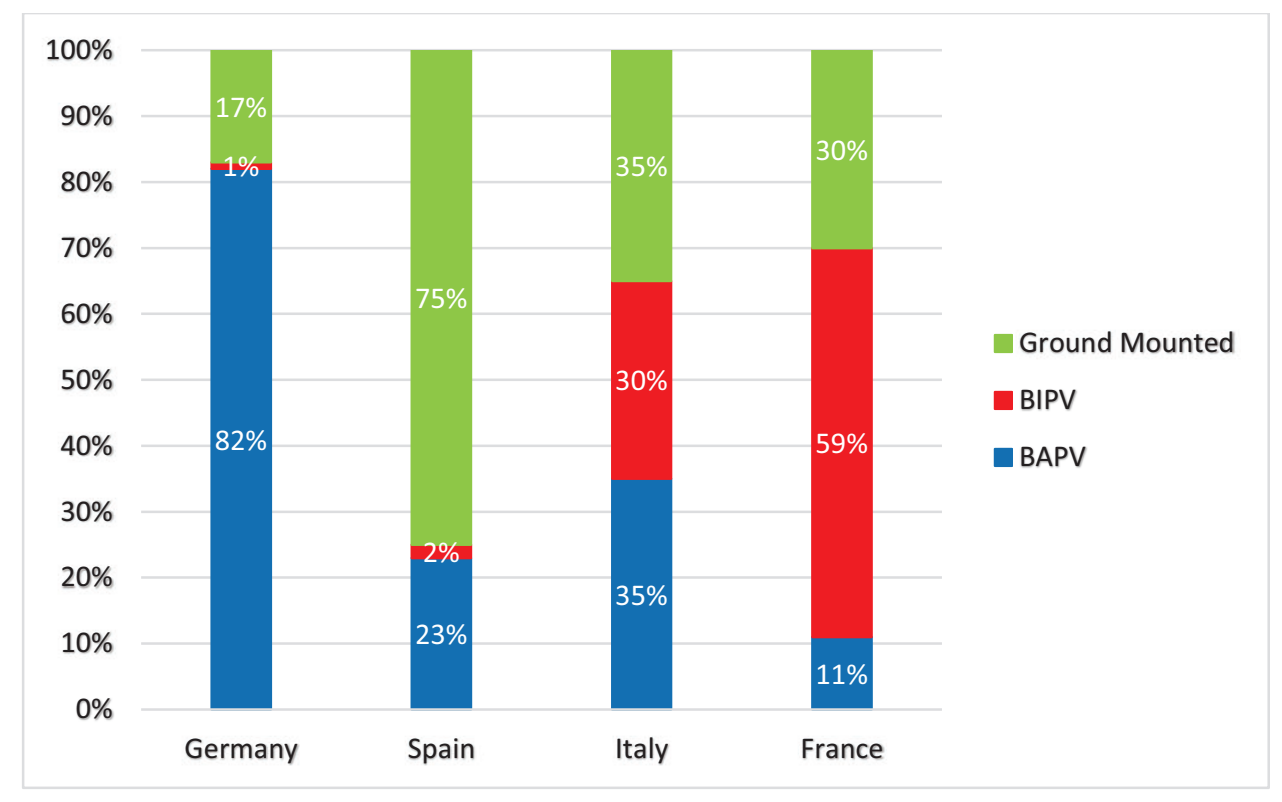

Fig 3: Application of BIPV in European countries [16] 
Table 1: European countries and BIPV support policy types [16].

\begin{tabular}{|ll|}
\hline Country & Type of Support \\
\hline Austria & Investment subsidy \\
\hline Czech Republic & Investment subsidy \\
\hline Denmark & Investment subsidy \\
\hline France & FiT and investment subsidy \\
\hline Italy & FiT and investment subsidy \\
\hline Slovenia & FiT \\
\hline Spain & Investment subsidy \\
\hline Switzerland & FiT \\
\hline
\end{tabular}

Table 1 shows the list of few other European countries which are introducing policies to promote BIPV application. Slovenia and Switzerland have implemented the Feed in Tariff (FiT) support policy. This means, a mechanism established to pay the energy users for generating the renewable energy. While in Austria, Spain, Denmark and Czech Republic have investment subsidy support policy. For example, Austrian government in 2013 introduced a policy to offer $€ 300$ for free standing/roof mounted PV system and $€ 400$ for BIPV with upper limit of $5 \mathrm{kWp}$ [17]. The reason behind the significant use of BIPV in France and Italy is due to the favorable government policies. The table shows that France and Italy have adopted both FiT and investment subsidy policy to promote renewable energy.

\subsection{BIPV Cells}

General BIPV cell technology is based on crystalline silicon or thin film. Crystalline silicon is an established technology because of the higher energy conversion efficiency which ranges from 13-21\% [18]. While integrating into glass envelope (roof, wall, window), the solar cells are arranged to create gap between cells that allows sunlight to pass through. 
Similarly, thin film solar cells are flexible light weight compared to crystalline silicon technology. These are applied where greater flexibility (curve roofs, facade) and weight constrains are the limitations. Copper Indium Gallium Selenide (CIGS), Cadmium Telluride (CdTe) and amorphous silicon are the commonly used thin film technologies. The efficiency of CdTe solar modules range from $9-13 \%$ [18] while the amorphous silicon offer lower efficiency from 6-10\% [18] only.

Table 2: Summary of BIPV details from the literature review

\begin{tabular}{|c|c|c|c|}
\hline PV Cell Information & Capacity & Application & Source \\
\hline $\begin{array}{l}\text { - } \text { Amorphous silicon (a-Si) } \\
\text { - Semi- transparent (Thin film) } \\
\text { - Transmittance }=30 \%\end{array}$ & $3.5 \mathrm{~kW}$ & $\begin{array}{l}\text { Curtain Wall } \\
\text { (Burnaby, Canada) }\end{array}$ & [3] \\
\hline $\begin{array}{ll}\text { - } & \text { Monocrystalline } \\
\text { - } & \text { Mono } 156 \text { watt } \\
\text { - } & \text { Efficiency }=16.8 \%-17.8 \%\end{array}$ & $1.56 \mathrm{Kw}$ & $\begin{array}{l}\text { Slope glass roof } \\
\left.\text { [19.5 } \mathrm{m}^{2}\right] \\
\text { (Toronto, Canada) }\end{array}$ & [5] \\
\hline 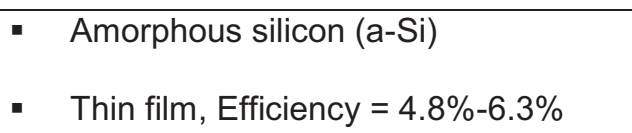 & NA & $\begin{array}{l}\text { Double Glazed Window } \\
\text { (Korea) }\end{array}$ & [6] \\
\hline $\begin{array}{l}\text { - } \\
\text { - } \quad \text { Efficiency }=4.8 \%-6.3 \% \\
\text { - } \quad \text { Solar Transmittance }=10 \%-80 \%\end{array}$ & NA & $\begin{array}{l}\text { Double Glazed Window } \\
\text { (Japan) }\end{array}$ & {$[8]$} \\
\hline $\begin{array}{l}\text { - } \text { Polycrystalline } \\
\text { - Efficiency }=12 \%-14 \%\end{array}$ & NA & $\begin{array}{l}\text { Roof, Sun Shading } \\
\text { (Korea) }\end{array}$ & [9] \\
\hline $\begin{array}{l}\text { Amorphous silicon }(\mathrm{a}-\mathrm{Si}) \\
\text { - Semi- transparent, Efficiency }=6.6 \%\end{array}$ & NA & $\begin{array}{l}\text { Double Skin Façade } \\
\text { (Hong Kong) }\end{array}$ & [10] \\
\hline $\begin{array}{l}\text { - } \quad \text { Polycrystalline } \\
\text { - } \quad \text { Efficiency }=15.8 \% \\
\text { - Semi- transparent }\end{array}$ & $177 \mathrm{kWh}$ & $\begin{array}{l}\text { Double Glazed Window } \\
\left(1.68 \mathrm{~m}^{2}\right) \\
\text { (Lithuania) }\end{array}$ & [18] \\
\hline
\end{tabular}




\section{Methodology}

The primary objective of this research was to analyze the impact of BIPV application in the Architectural Science Building (ARC) of Ryerson University. It was intended to understand the changes in primary energy demand (heating, cooling, and lighting), daylighting, heat gains and electricity production capacity of BIPV. The study focused on the faculty office area (south and west facing rooms) located on $3^{\text {rd }}$ Floor of ARC Building. In order to conduct the research, either a proven methodology had to be followed or an acceptable methodology had to be established. In this case, an experimental study of BIPV conducted in Lithuania was taken as reference source (For detail in Section 4).

The idea was to reproduce the results of reference source using the available data, information and make the comparison to establish validation. For the performance analysis, the building can be simulated using the DesignBuilder (DB) software. DesignBuilder (DB) is a software for building energy simulation that allows to check the energy consumption of the building. It uses configurations like building envelope details to create a three dimensional volume of a given building. It uses and also supports energy plus weather (epw) data of a particular place (default/actual) to give the results. The program allows to choose a wide range of details from its extensive library to create a mock-up of the existing building or proposed design for higher accuracy. As a result, it allows to test the building performance under different parameters like building's energy use intensity, thermal efficiency, lighting, comfort, cost factor and many more. For this study, DesignBuilder v5 will be used as a simulation tool. 
Once the DesignBuilder (DB) validation is established, the analysis of ARC building was carried out by creating a base model of the ARC building in DesignBuilder. All the construction details of wall, windows, floor plans, sections and respective heights were used to create a mock - up of ARC building for simulation. The results of simulation were compared with the actual annual energy demand of the ARC building. There was also a plan to include studio located on the west side of third floor in the analysis. At the moment, the studio is open to atrium space. Which means if the studio is included in the analysis, technically, the space heating, cooling calculation is connected to the common space (atrium). The atrium is a big space and the overall impact of BIPV application for heating and cooling may be less effective. However, the electricity generation and daylighting analysis could be similar to the faculty office area. So the analysis was focused to the faculty office area located on the south and west side. The performance of BIPV application was further analysed under 5 possible ways of BIPV application and the results were compared with the base model. Finally, the discounted payback period calculation was performed to check the financial feasibility of BIPV application. 


\section{DesignBuilder (DB) validation}

For the validation of the simulation, energy modelling simulation of the experimental study in Lithuania was reproduced in DB. The report explains the advantages of using semitransparent BIPV when analyzed from the multi-criteria perspective. It's a comparative study of two south facing office rooms located in Lithuania where one has transparent façade and another BIPV façade. The given dimensions $3 \mathrm{~m} \times 5 \mathrm{~m} \times 2.5 \mathrm{~m}$ are depth, length and height respectively. All the partitions were considered adiabatic and the given $\mathrm{U}$-value of the window is $0.8 \mathrm{~W} / \mathrm{m}^{2} \mathrm{~K}$.

The window to wall ratio (WWR) is $88 \%$ in the case of transparent and BIPV façade has $47 \%$ transparent out of $88 \%$ glazed part. Other features like heating and cooling are considered as typical fan coil while LED light with linear control have been included. Ventilation and domestic hot water systems have not been simulated because their energy demand is not influenced by glazing. The total primary energy demand of the office after application of PV on the window decreased from $171 \mathrm{kWh} / \mathrm{m}^{2}$ year to 96 $\mathrm{kWh} / \mathrm{m}^{2}$ year, the annual solar heat gains reduced to $94 \mathrm{kWh} / \mathrm{m}^{2}$ year from 181 $\mathrm{kWh} / \mathrm{m}^{2}$.year and the BIPV produced $385 \mathrm{kWh}$ electricity annually [19]. The simulation result shows that compared to transparent window, PV application improves the comfort by reducing the solar heat gain, decreasing the cooling load and generated power on site. 

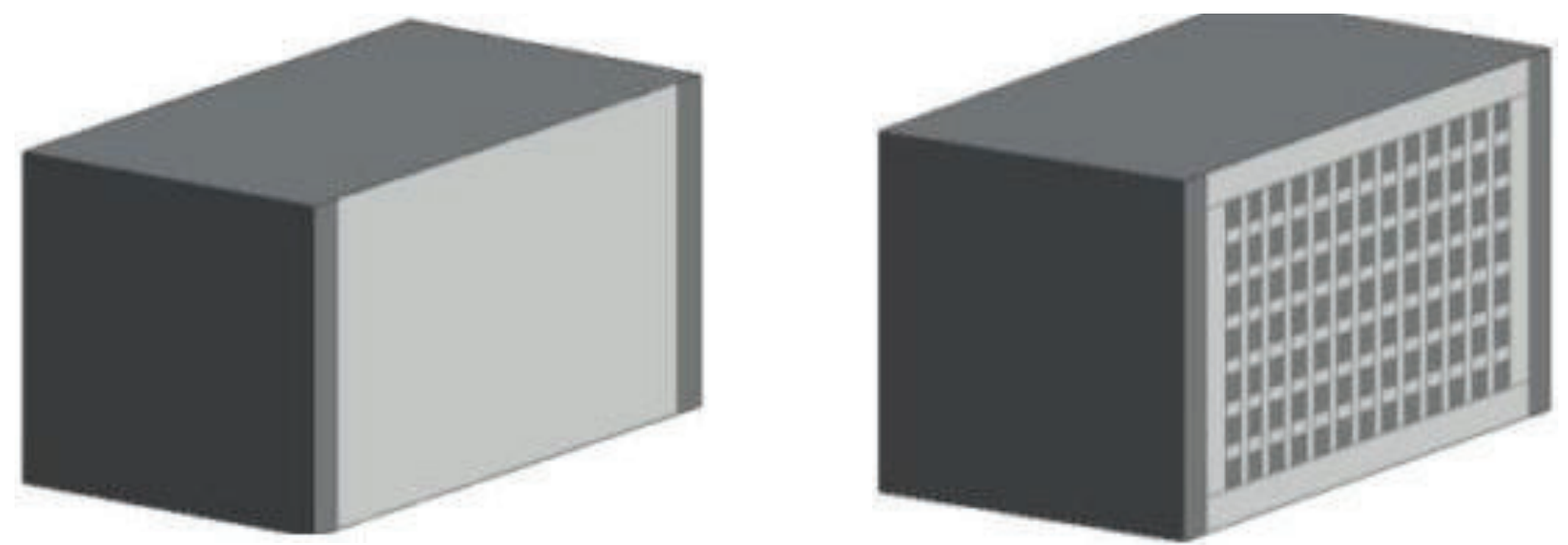

Fig 4: Case Study- Transparent and BIPV façade [19]
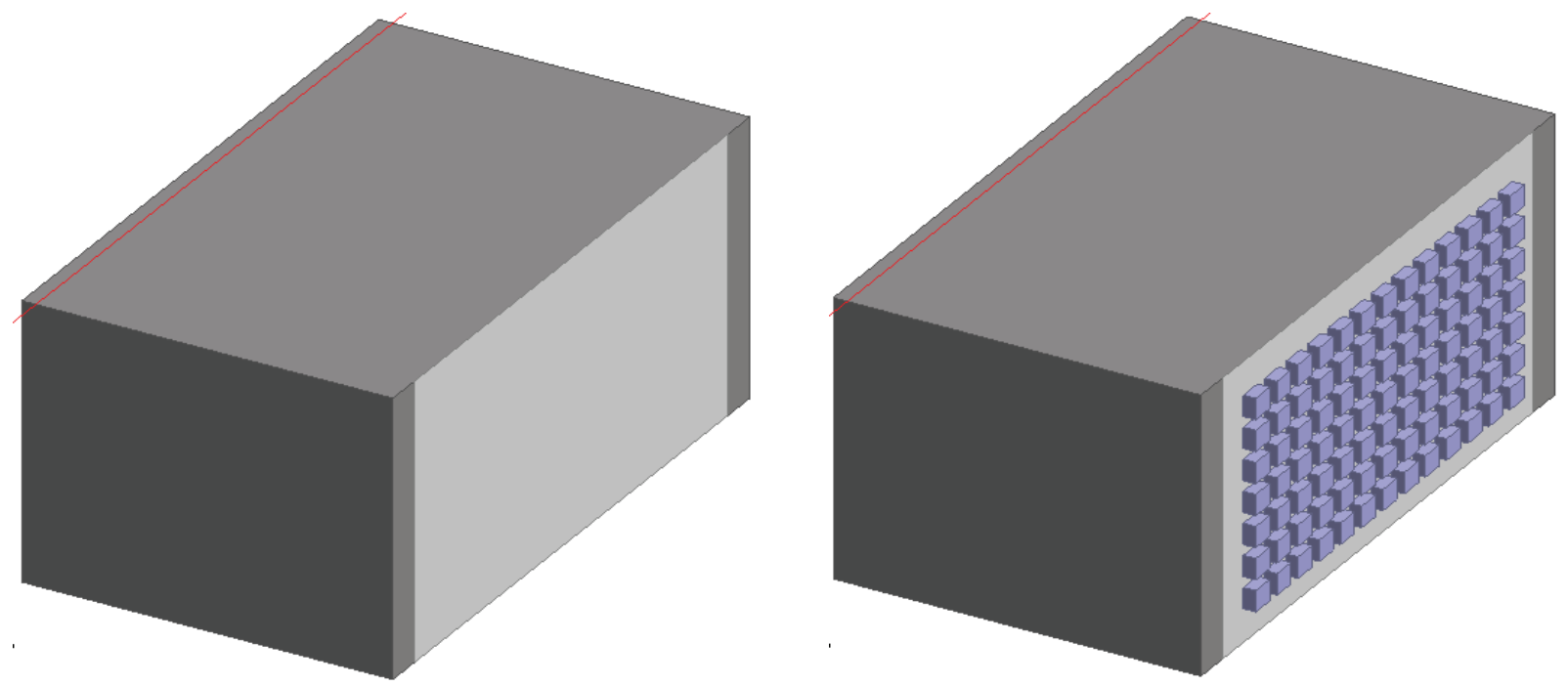

Fig 5: Image of simulation reproduced in DB

Window details like number of panes, glass thickness, gap between the panes, type of frame, were not clearly mentioned in the case study report. In order to achieve the given U-value $\left(0.8 \mathrm{w} / \mathrm{m}^{2} \mathrm{~K}\right)$, multiple combination for window were tried during the simulation process. It was evident from literature review (NRC-CNRC-Building Science for Cold Climate) that at least triple pane windows would be required to achieve the given U-value. During an e-mail communication, the author simply mentioned that it was double pane window, providing no further details of the window combination. So the strategy was to 
simulate window combinations that would provide one of the highest $U$-values for double and triple pane. For a double pane, a combination of Lo-E Clear glass $6 \mathrm{~mm}$ with $13 \mathrm{~mm}$ air gap provided the $\mathrm{U}$-value of $1.8 \mathrm{w} / \mathrm{m}^{2} \mathrm{~K}$. And in the case of triple pane, a combination of Lo-E Clear glass $3 \mathrm{~mm}$ with $13 \mathrm{~mm}$ gap filled with argon gave the U-value $0.8 \mathrm{w} / \mathrm{m}^{2} \mathrm{~K}$. In both the cases, thermally broken aluminum frames were included. Taking these window fenestration details, the simulation was carried out for both double and triple pane windows.

\subsection{Simulation with default weather file}

Figure 6 shows the comparison between the case study and the simulation result. While using the default weather file, the results of case study and simulation were in sharp contrast to the month to month performance as well as on the total annual basis. The figure shows the solar heat gains in case study drops from January to February and gradually rises during March reaching highest in April and October with lowest value during December. The simulated result shows that the solar heat gains constantly rising from January to May and slightly drops in June and July. But it rises again to maximum during August then gradually declines to the lowest value in December. 


\subsubsection{Solar heat gains with default weather file}
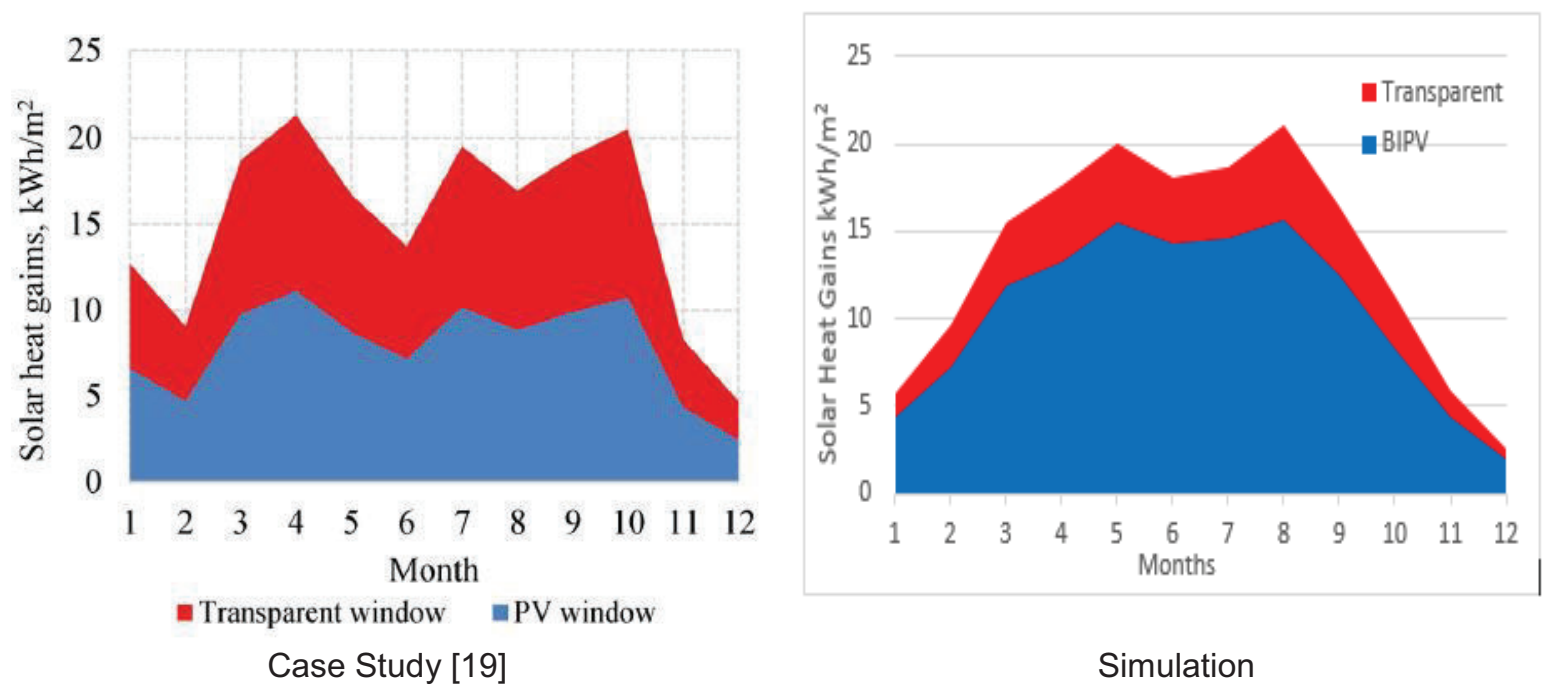

Fig 6: Solar heat gains (with default weather file)

Table 3: Annual Solar heat gains comparison $\left(\mathrm{kWh} / \mathrm{m}^{2}\right)$ with default weather file

\begin{tabular}{c|c|c|c}
\hline & BIVP Window & Transparent Window & Remarks \\
\hline Case Study & 94 & 181 & $48.06 \%$ less due to BIPV \\
\hline Simulation & 124.13 & 161.82 & $23.67 \%$ less due o BIPV \\
\hline
\end{tabular}

Table 3 shows summary of the simulation result. The solar heat gains in case of transparent window is $162.63 \mathrm{kWh} / \mathrm{m}^{2}$ with BIPV application and the solar heat gains reduces to $124.13 \mathrm{kWh} / \mathrm{m}^{2}$. After the application of BIPV, the solar heat gains seems to reduce around $24 \%$ whereas, case study shows the reduction by $48 \%$ when default weather file was used. Compare to the case study, the annual solar heat gains in transparent window application is around $11 \%$ less but almost $30 \%$ greater in BIPV application. 


\subsubsection{Heating, Cooling and Lighting Energy Demand (default weather file)}

Figure 7 shows overview of heating, cooling and lighting energy demand of case study and simulation result using default weather file. Though the simulation and case study result differ, the reduction in the primary energy demand (heating, cooling and lighting) due to BIPV application can be seen. The lighting is least affected but the heating energy demand increases by $20 \%$. The cooling energy demand reduces almost by $65 \%$ which proves significant for an office building.
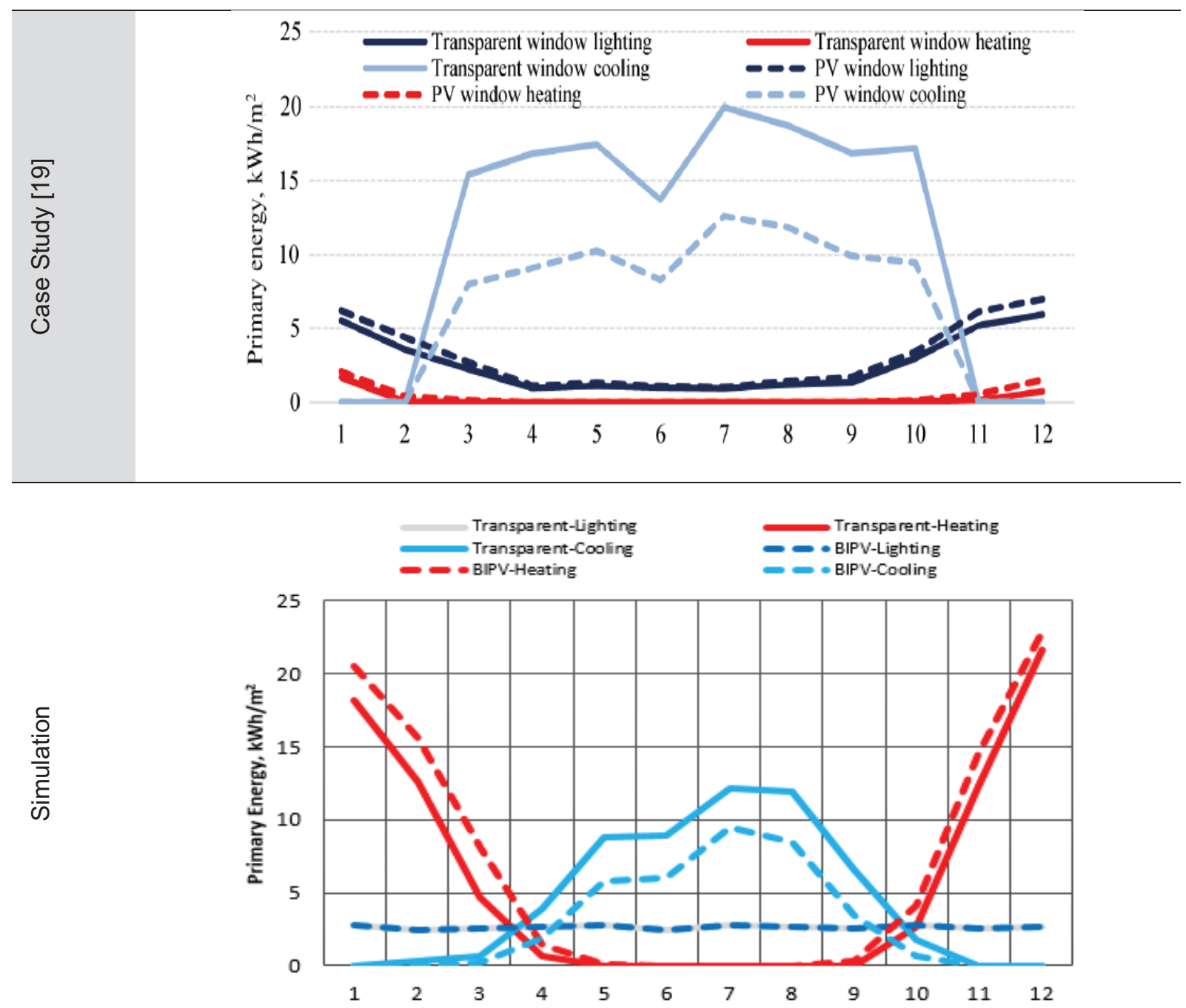

Figure 7: Heating, Cooling and Lighting energy demand comparison (default weather file) 


\subsection{Simulation with actual weather file}

The table and figure below shows the comparison between the case study and the simulation result. While using the actual weather file, the results of case study and simulation result seems have the similar month to month performance as well as on the total annual pattern. During the transparent window application, the figure shows similarity in the month to month solar heat gains with highest during April and October with lowest heat gains in December. After the application of BIPV, the results shows that it resembles the month to month fluctuation with the case study but the solar heat gains value seems much higher in the simulation results.

\subsubsection{Solar heat gains with actual weather file}

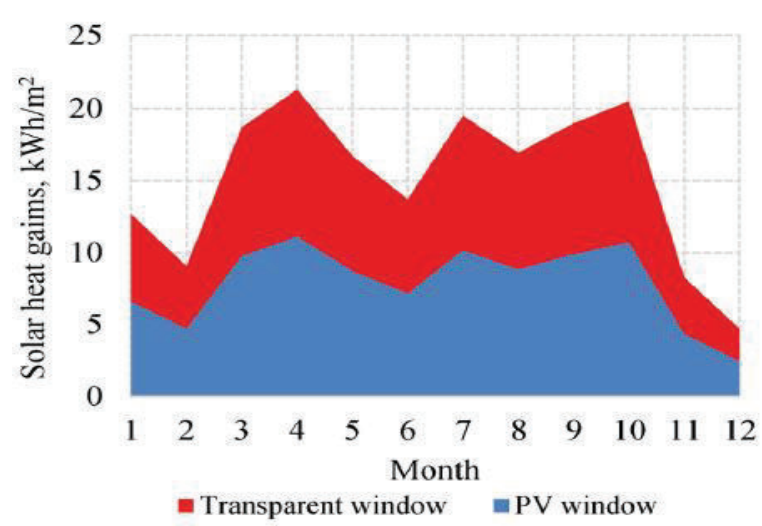

Case Study [19]

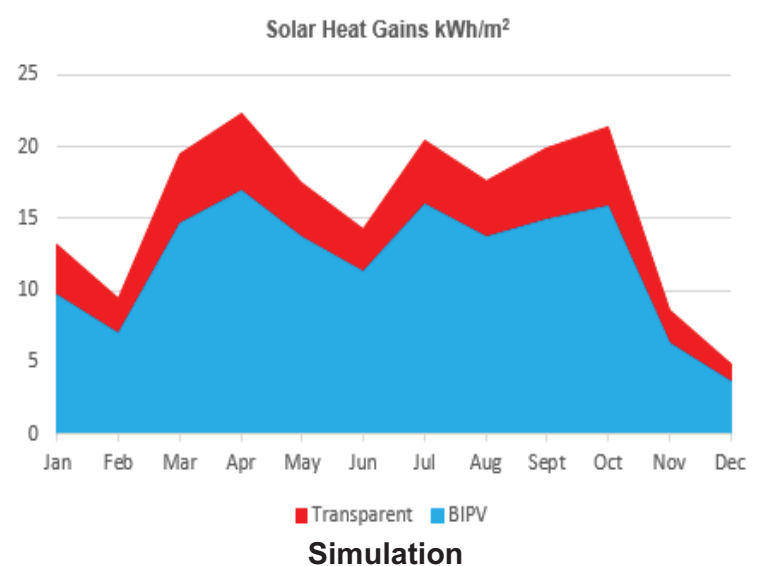

Simulation

Fig 8: Solar Heat Gains with actual weather file

Table 4: Annual Solar heat gains comparison $\left(\mathrm{kWh} / \mathrm{m}^{2}\right)$ with actual weather file

\begin{tabular}{l|l|l|l}
\hline & BIVP Window & Transparent Window & Remarks \\
\hline Case Study & 94 & 181 & $48.06 \%$ less due to BIPV \\
\hline Simulation & 142 & 189 & $32.16 \%$ less due o BIPV \\
\hline
\end{tabular}

Table 4 shows the summary of the simulation result compared to case study. The solar heat gains in case of transparent window is $189 \mathrm{kWh} / \mathrm{m}^{2}$ which reduces to 
$142 \mathrm{kWh} / \mathrm{m}^{2}$ with BIPV application. After the application of BIPV, the solar heat gains seems to reduce around $33 \%$ whereas, case study shows the reduction by $48 \%$ when actual weather file was used. Compare to the case study, the annual solar heat gains in transparent window application is around $4 \%$ higher but almost $52 \%$ greater in BIPV application.

\subsubsection{Heating, Cooling and Lighting Energy Demand (actual weather file)}
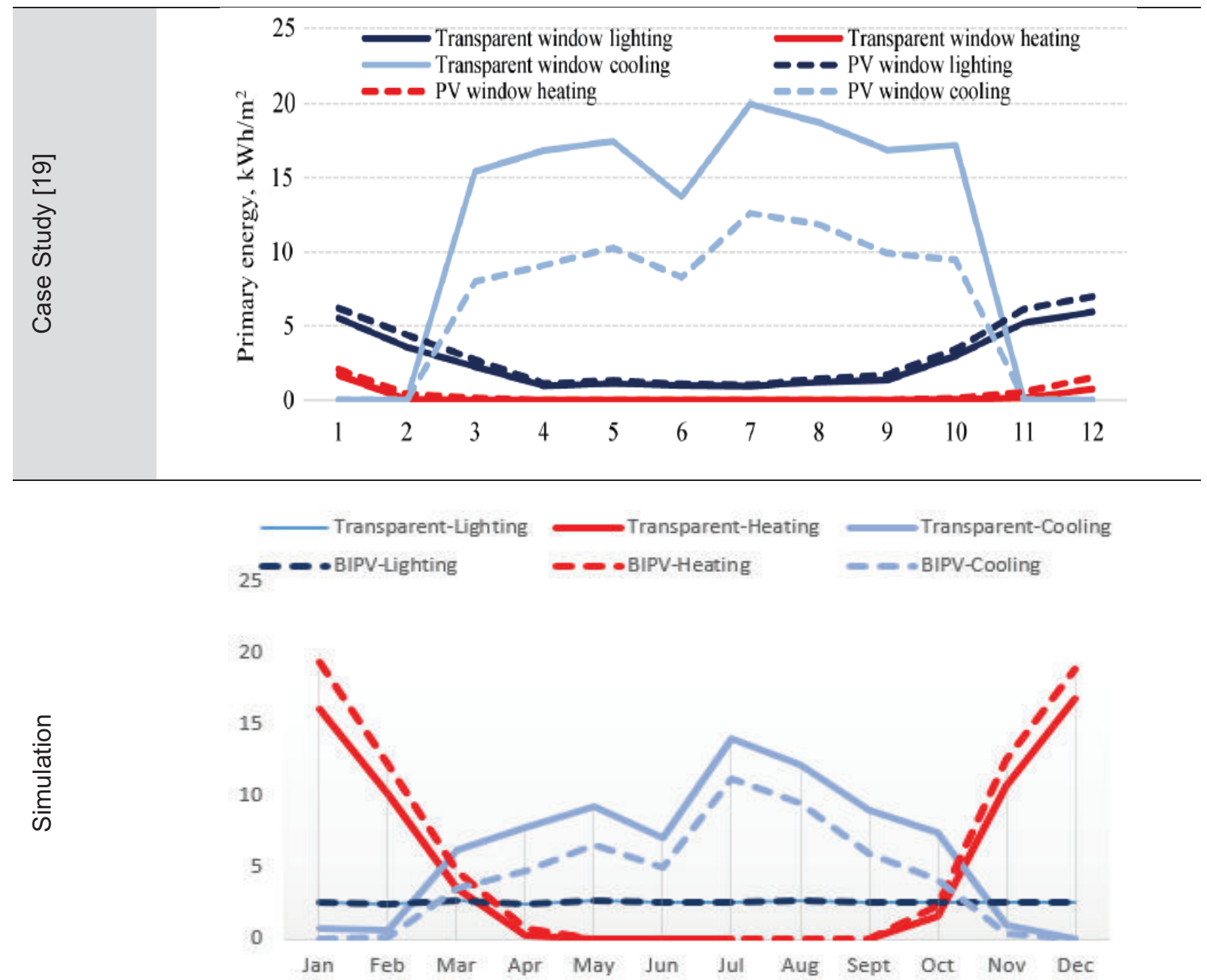

Primary Energy Demand, kWh/m²

Figure 9: Heating, Cooling and Lighting energy demand comparison (actual weather file) 
Figure 9 shows the monthly primary energy demand comparison between case study and simulation results while using the actual weather file. In the case study, the cooling demand drops down significantly with BIPV application. It shows that the cooling demand is least during January-February and November-December. The cooling demand rises from March to May which drops slightly in June and reaches the maximum during July. It can be observed that there is sharp rise from February to March and steep drop from October to November. On the other hand, the simulation result shows that there is an overall decrease in cooling energy demand while the heating demand increases. The result shows that the heating is required from January-March and October-December. Whereas the cooling demand starts from March, with the highest during July and ending in November.

From the solar heat gains and primary energy demand comparison between case study and simulation, it can be understood that the window detail and the weather data file played an important role. In the case of transparent window the solar heat gains followed the very similar pattern. But in the case of BIPV application, the solar heat gains values remain relatively higher (monthly and annually) than the case study. In the primary energy demand analysis, the cooling demand displays the similar pattern while the heating and lighting pattern differ from the case study.

\subsection{Electricity production}

As described in the case study, two different simulations were performed to compare the electricity generation results. At first, the actual area of monitored cells $\left(1.68 \mathrm{~m}^{2}\right)$ was simulated. The simulation of solar cells (with efficiency $=15.8 \%$ ) generated 
188.02 kWh electricity while the actual monitored shows $177 \mathrm{kWh}$ annually. Table 5 shows the monthly comparison results between monitored (case study) and simulation. The PV electricity production result shows that in both cases, there are similarities in monthly electricity production trend. Figure 10 shows that in most of the months, the difference is below $15 \%$ but July and November have significantly higher differences. While the rest of the months have the similar values to that of monitored cells, it is difficult to explain the exact reason behind the variations in those particular two months. Even with bigger differences in July and November, there is only $6.22 \%$ difference in the annual electricity generation. Secondly the simulation of cell area of $3.64 \mathrm{~m}^{2}$ generated $386.97 \mathrm{kWh}$ electricity annually. Compared to the case study $(385 \mathrm{kWh})$, there is less than $1 \%$ difference in the annual electricity production.

Table 5: Comparison between monitored and simulated BIPV electricity

\begin{tabular}{l|c|c|c|c|c|c|c|c|c|c|c|c}
\hline & Jan & Feb & Mar & Apr & May & Jun & Jul & Aug & Sep & Oct & Nov & Dec \\
\hline Monitored & 13 & 9 & 20.5 & 21 & 18 & 14.5 & 17 & 18 & 19 & 19 & 3.5 & 4.5 \\
\hline Simulated & 11.29 & 8.43 & 18.81 & 23.1 & 19 & 15.39 & 22.5 & 18.7 & 19.6 & 19.4 & 7.53 & 4.18 \\
\hline \% Difference & $\mathbf{1 3 . 1 5}$ & $\mathbf{6 . 3 3}$ & $\mathbf{8 . 2 4}$ & $\mathbf{1 0}$ & $\mathbf{5 . 5 6}$ & $\mathbf{6 . 1 4}$ & 32.4 & $\mathbf{4 . 1 1}$ & $\mathbf{3 . 3 2}$ & $\mathbf{2 . 1 1}$ & 115.14 & $\mathbf{7 . 1 1}$ \\
\hline
\end{tabular}

PV Window electricity (kWh/month) generation comparison monitored vs simulated

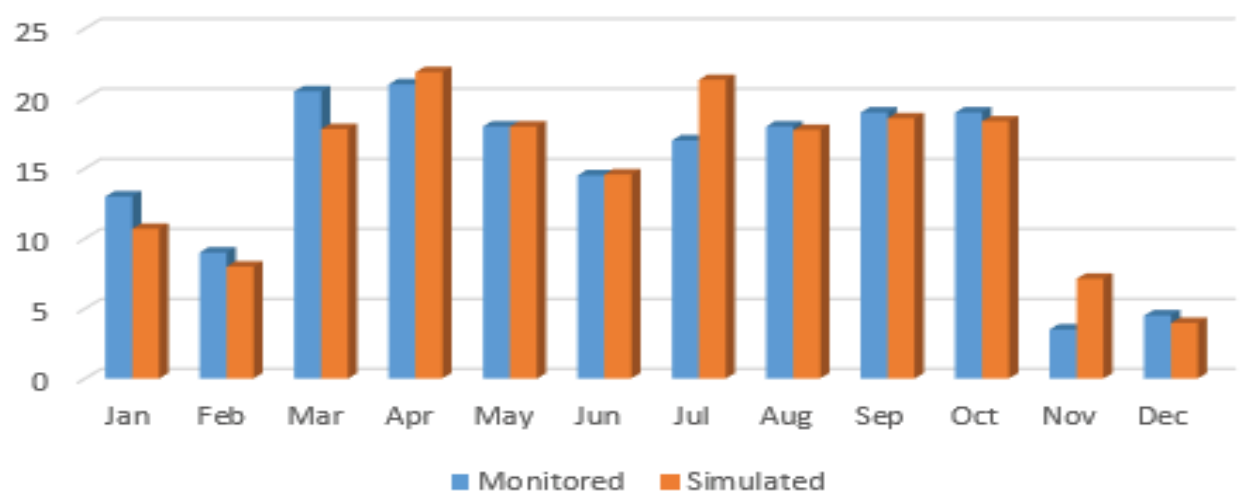

Fig 10: Overview of monthly electricity generation 
The simulations result shows that the solar heat gains and primary energy demand (heating, cooling, and lighting) in both the cases (double and triple pane) were not close to case study results. Not only the annual values were different, the monthly pattern of energy demand and solar heat gains were also not matching. The contrast results were due to the weather file. Author had used the data from the weather station to create a weather file and used for the simulation. The monthly heating demand in case study seems extremely low suggesting that the building must have been a super air tight. The missing of detail information about the simulation could be one reason leading to differential values between the case study and the simulation results. The weather data provided by the author was instrumental. Results after using the actual weather file shows that the solar heat gains follow the similar pattern to that of the case study. Also the cooling and electricity production display similar monthly and yearly profile. In general, the increase in heating demand, decrease in cooling demand shows the impact of BIPV application. 


\section{Building under study}

The Architectural Science Building (ARC) of Ryerson University located at 325 Church Street, Toronto, ON was selected for this experimental study. With reference to the design drawings, probably, ARC building was in the late 70 s or early 80 s. Adjacent taller building to the North is Monetary Times Building (MON) while Eric Palin Hall (EPH) and Pitman Hall (PIT) lies to the east. Further south and west are Rogers Communications Centre (RCC) and Kerr Hall East (KHE) located respectively. The ARC buildings is used by the Department of Architecture and Building Science of Ryerson University.

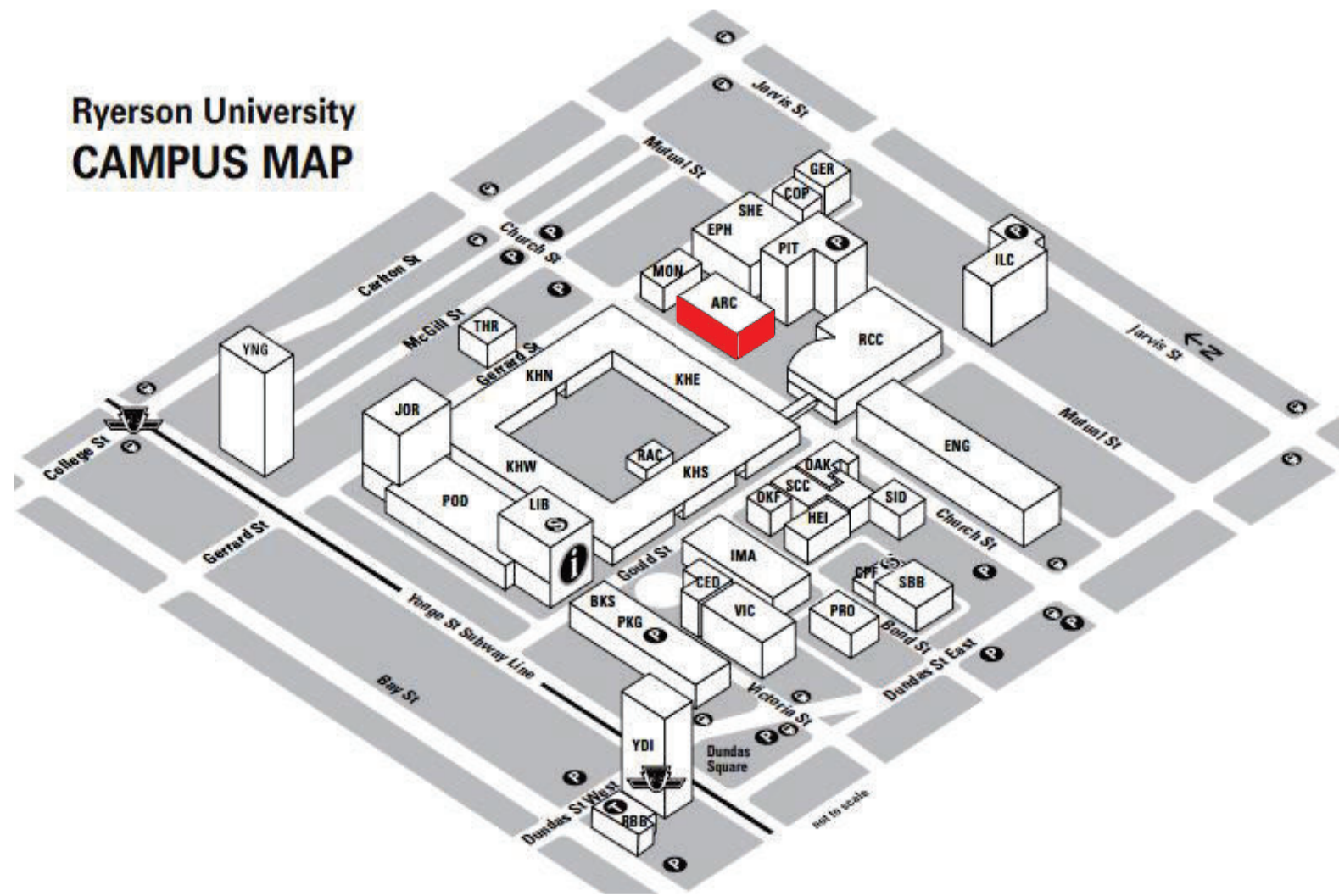

Fig 11: Ryerson University Campus Map [20] 
It is a simple rectangular shaped four storey building with built up area $6686.34 \mathrm{~m}^{2}$ and the given floor height is $3.5 \mathrm{~m}$. There are two centrally located atriums. The classrooms, studios, offices and the other supporting facilities are accommodated towards the north and south of atriums. The building features "ribbon window" as architectural expression punctuated with the use of spandrel regardless of the orientation and position of the windows.

\subsection{Site Analysis}

Site analysis was carried out in order to understand the physical location, surround buildings, vegetation, orientation and present condition of the building. All these factors play an important role in finding the current issues that leads to thought synthesis and analysis for design solution. The following sections will explain and highlight the issues, orientation of the building, shadow cast analysis, window to wall ratio analysis.

\subsubsection{Current issues}

Due to overheating and excess day lighting, the indoor environment in office are not always pleasant. Currently, window blinds are being used to keep the excess light for minimising the glare issue. At the same time, the offices are dependent of the artificial lights to perform activities. This eventually has impact on the operation cost and the environment. Apparently, there seems to be glare issues particularly on the south west and south east side, where the studios-offices are located. Currently, window blinds and sticking paper on to the windows, have been observed as a temporary solution. Also the studio space where architecture students spend significant time has the similar issue. In both the case the heat and 
light from the sun is creating discomfort. The objective of the study is to understand the impact of proposed BIPV application on windows Third Floor Faculty Office areas facing south east and south west.

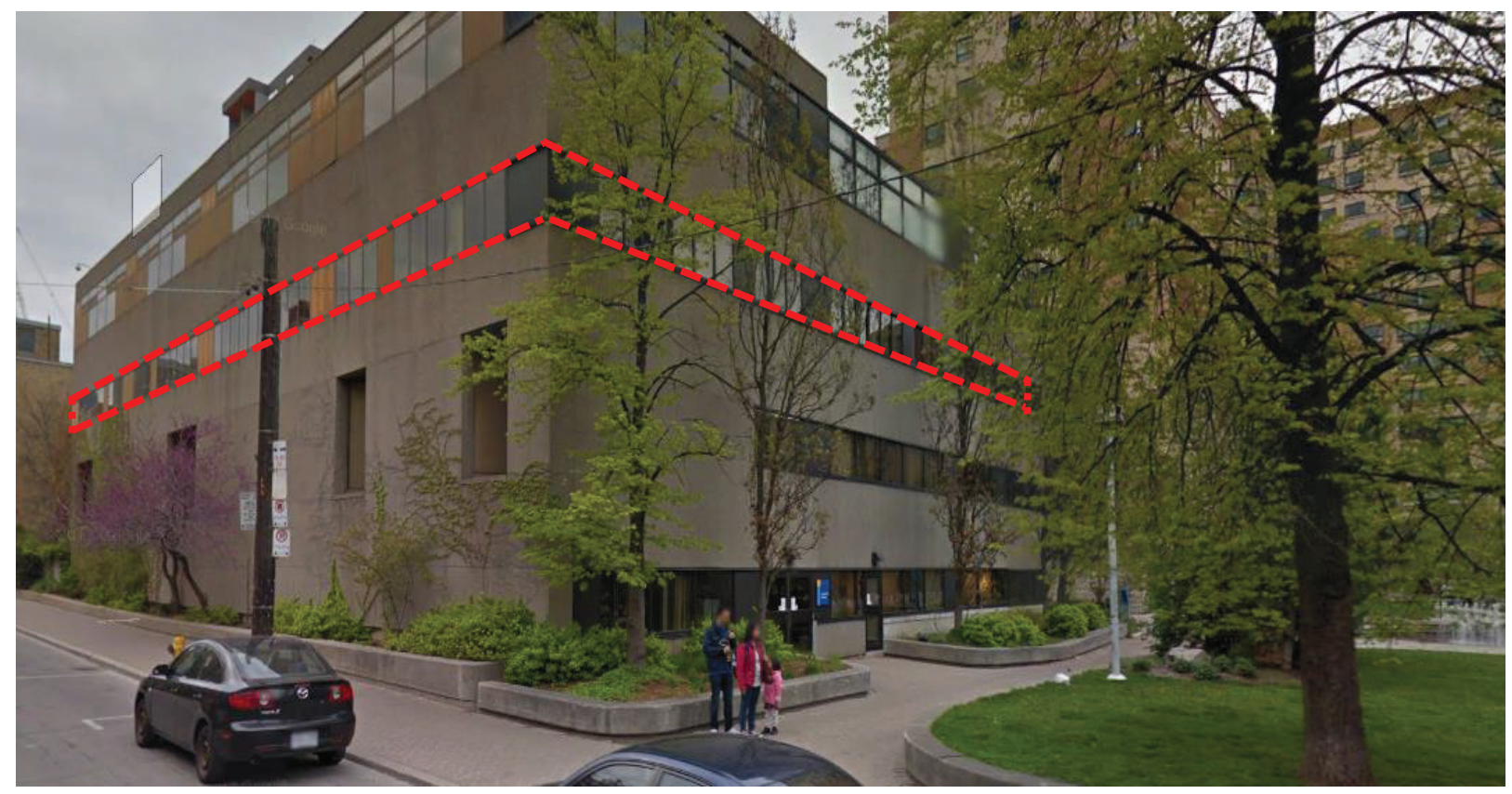

Fig 12: View of West and South façade of ARC Building [21]

\subsubsection{Orientation}

The orientation and the shadow cast plays an important role in understanding the site potential and developing a design strategy according. The geographical position of the ARC Building 325 Church Street, Toronto, Canada is latitude: 45.15 and longitude: 79.39 west (source: google earth pro). The figure 13 suggests that on the longest day, the sun rises at 58 degree northeast and sets at 302 degree north west. While sun rises at 122 degree southeast and sets at 238 degree southwest on the shortest day. The ARC building is slightly tilted at an angle of 17 degree thus creating a ture north at 73 degree. 
Toronto, Canada - Sun path diagram

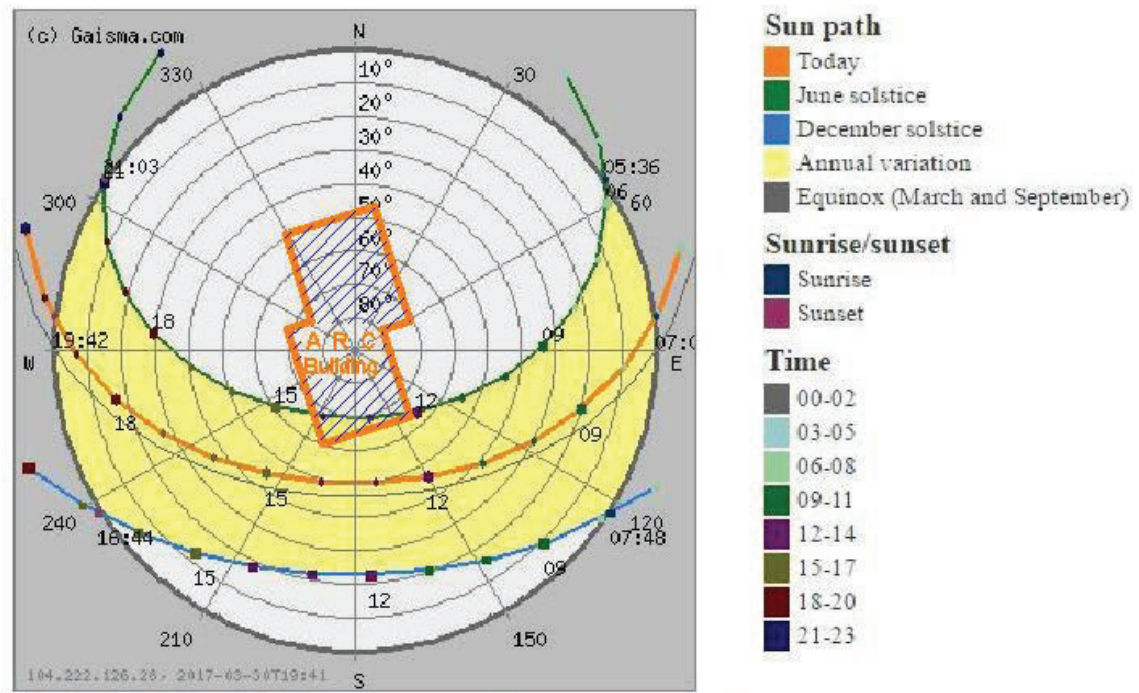

Fig 13: Sun path diagram of ARC Building [22]

\subsubsection{Shadow cast}

A shadow cast analysis was conducted in the google sketch up. The site plan was created including the neighboring structures (buildings and trees) that could potentially cast shadow on the windows. EPH and PIT building are located to the east direction, RCC is located to the south east and KHE is located to the west directions. The height of the surrounding structures were decided based on visual inspection (number of storeys) and standard floor height $3.5 \mathrm{~m}$. On the south side, there are 3 trees adjacent to the ARC building that seems to cast shadow on the glass. There is another tree on the west corner but its shadow impact seems to be less. The dates chosen for shadow cast study are March 21, June 21, September 21 and December 21. And the shadow cast observation was done at 10, 12 and 15 hours of the above mentioned dates. An overview of the shadow cast analysis are explained in the following page. 


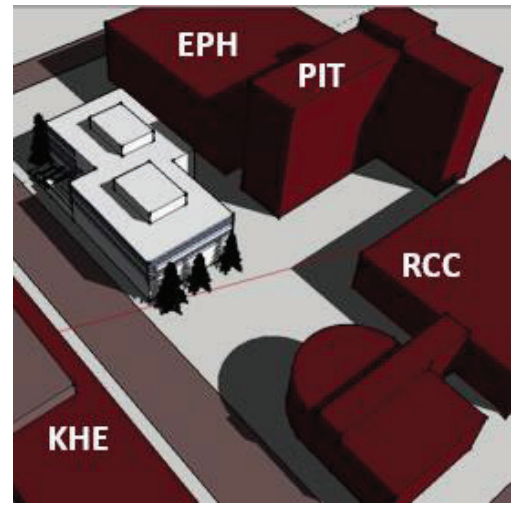

10 hours

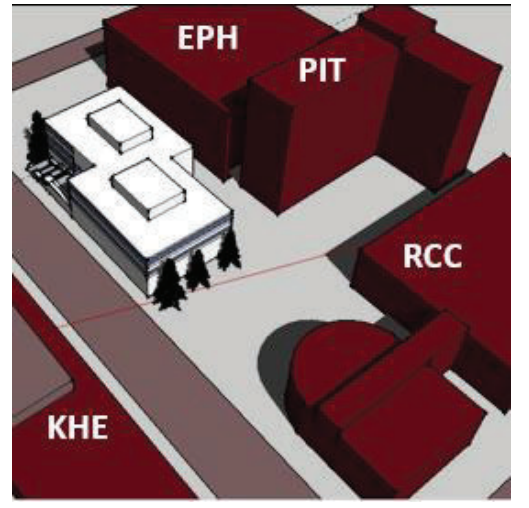

12 hours

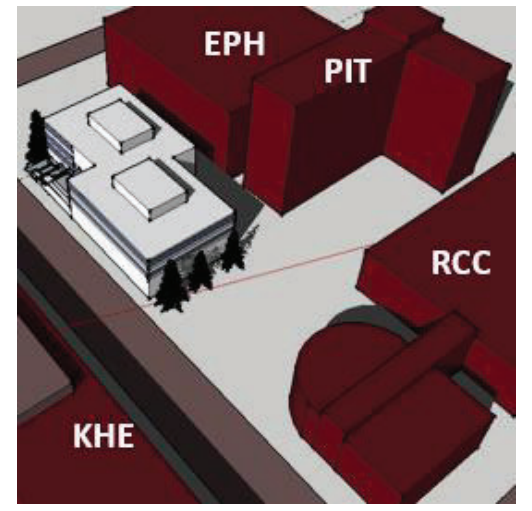

15 hours

Fig 14: Shadow cast analysis of March 21

Figure 14 includes the shadow analysis of March 21. On this day, until 12 hours, the south side is exposed to sun light. The shadow of KHE does to strike the west façade of the ARC building until 15 hours. This means the BIVP on the south will be productive until 12 hours and the BIPV on the west becomes productive only after 12 hours. The adjacent trees seem to cast shadow on the south side.

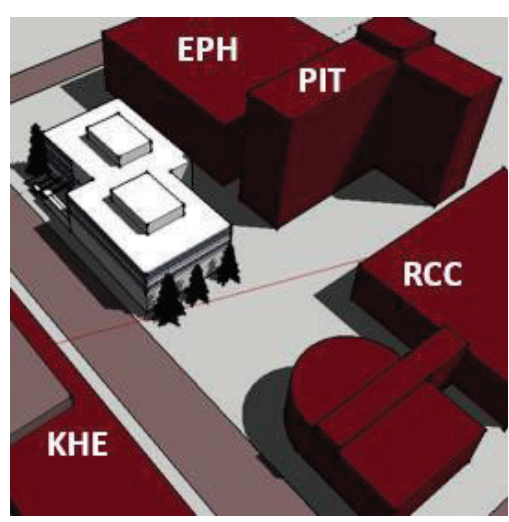

10 hours

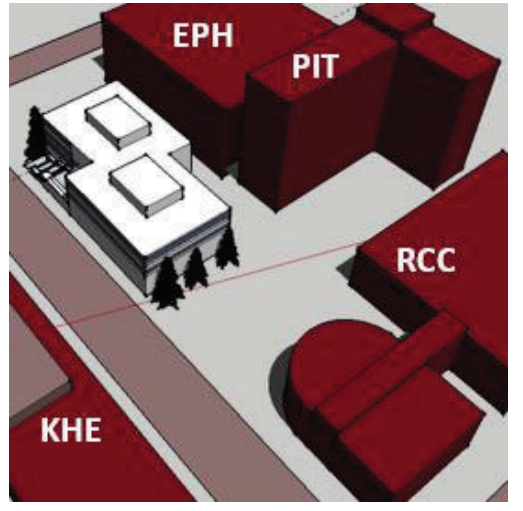

12 hours

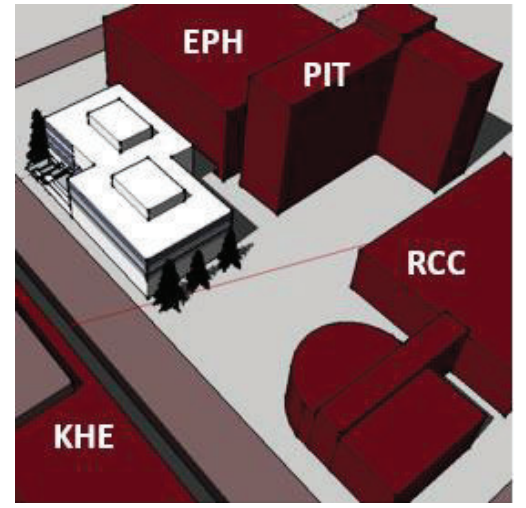

15 hours

Fig 15: Shadow cast analysis of June 21

Figure 15 shows the shadow cast analysis of June 21 . On the longest day (June 21), the trees on the south east does not seem to cast shadow even during 10 
hours. There is also no shadow cast from the KHE during 15 hours. The longer sun hours will positively impact in the electricity production of BIPV.

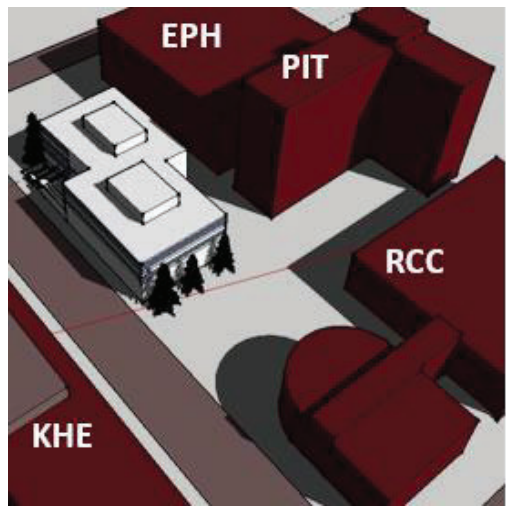

10 hours

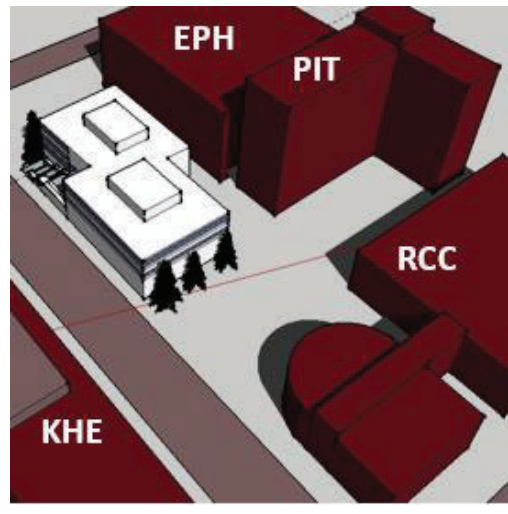

12 hours

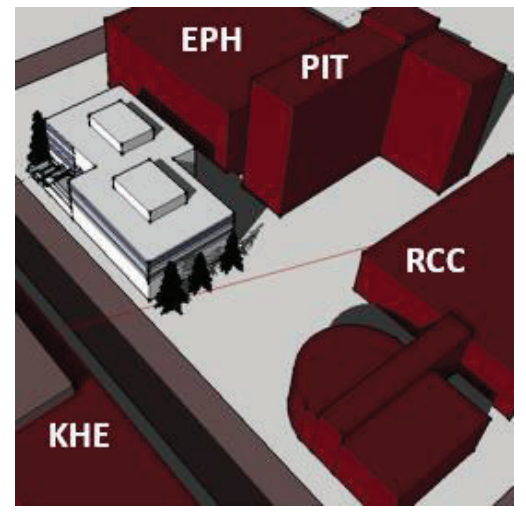

15 hours

Fig 16: Shadow cast analysis of September 21

Similarly figure 16 shows the shadow cast analysis of September 21 . The shadow cast pattern is similar to that of March 21 . Until 12 hours, the adjacent trees cast shadow on the south BIPV that will hamper the electricity production. Whereas the shadow cast of KHE do not fall on the west BIPV until 15 hours.

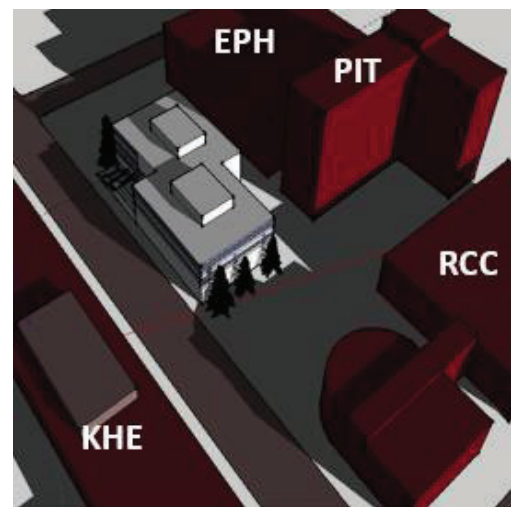

10 hours

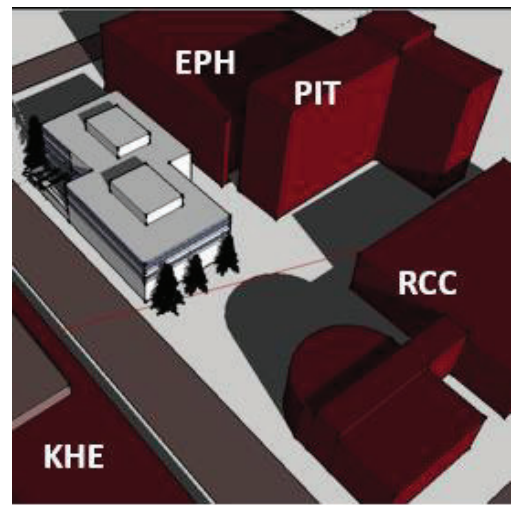

12 hours

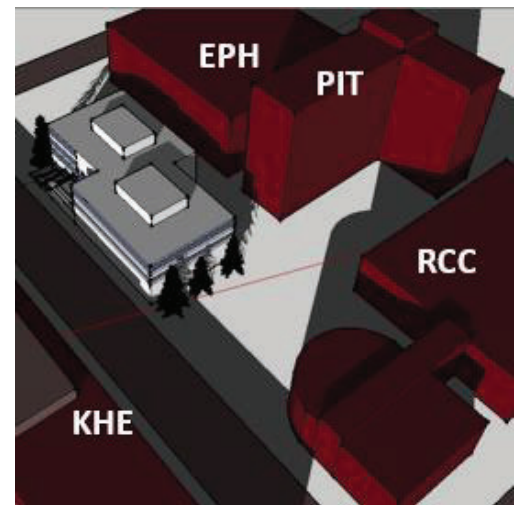

15 hours

Fig 17: Shadow cast analysis of December 21 
Figure 17 shows that on December 21, the trees on the south will cast shadow to the BIPV. But the west BIPV seems to be unaffected by the shadow cast of KHE from 12 hours until 15 hours. So the shadow cast analysis shows that the BIPV on the south seems to suffer from existing adjacent trees. Either trimming the top part of the tree or not installing the BIPV on the south east can be two options. Similarly, the west have no impact due KHE but it will be productive during the afternoon hours only.

\subsubsection{Window to wall (WWR) ratio analysis:}

The window to wall ratio has been calculated based on the architectural drawing available in the cad lab. There are spandrel panels on all the ribbon windows. So window to wall ratio has been calculated considering the window glazing part and entire ribbon window. Similarly, window glazing of the faculty offices on the south west side is around $29 \%$ and the ribbon window is just over $36 \%$. In the same way, the window glazing of the south east wall is $28 \%$ and the ribbon window is $36 \%$.

Table 6: Window to wall (WWR) area ratio calculation

\begin{tabular}{|c|c|c|c|}
\hline Description & Area $\left(\mathrm{m}^{2}\right)$ & WWR \% & Remarks \\
\hline \multicolumn{4}{|l|}{ Office: } \\
\hline West wall & 126.35 & & \\
\hline Window Glazing & 36.74 & 29.07 & 4 windows \\
\hline Entire Ribbon Window & 45.73 & 36.19 & \\
\hline \multicolumn{4}{|l|}{ Office: } \\
\hline South Wall & 95.90 & & \\
\hline Window Glazing & 27.55 & 28.72 & 3 windows \\
\hline Entire Ribbon Window & 34.71 & 36.19 & \\
\hline
\end{tabular}




\subsection{Simulation Description:}

The results of case study shows the effectiveness of BIPV application. To address the present issues of the ARC building, BIPV was proposed as an option. The analytical study and the methodology will be key tool to understand the impact of BIPV application. A base model of ARC building was modelled using the DesignBuilder (DB) software. Construction details of the exterior walls, partition walls, windows, floors were taken from the architectural drawings.

Table 7: Building Envelope details

\begin{tabular}{|c|c|c|c|c|}
\hline & & Thickness (m) & $\begin{array}{l}\text { R-Value } \\
\left(\mathrm{m}^{2} . \mathrm{K} / \mathrm{W}\right)\end{array}$ & U-Value $\left(\mathrm{W} / \mathrm{m}^{2} . \mathrm{K}\right)$ \\
\hline \multirow{3}{*}{$\begin{array}{l}\text { Exterior } \\
\text { Wall }\end{array}$} & Outermost Cast Concrete & 0.06 & \multirow[t]{3}{*}{2.47} & \\
\hline & Expanded Polystyrene (EPS) & 0.07 & & \\
\hline & Inner most cast concrete & 0.15 & & \\
\hline \multirow[t]{3}{*}{ Glazing } & Outer most Pane (Clear) & 0.006 & & \multirow[t]{3}{*}{2.66} \\
\hline & Window gas (air) & 0.013 & & \\
\hline & Inner most pane & 0.006 & & \\
\hline \multirow[t]{3}{*}{ Spandrel } & Outer most - Brown Aluminum & 0.002 & & \multirow[t]{3}{*}{1.835} \\
\hline & Expanded Polystyrene (EPS) & 0.015 & & \\
\hline & Inner most - Brown Aluminum & 0.002 & & \\
\hline \multirow[t]{2}{*}{ Floor } & Cast Concrete & 0.275 & \multirow[t]{2}{*}{0.485} & \\
\hline & Brick Tile & 0.015 & & \\
\hline \multirow{3}{*}{$\begin{array}{l}\text { Interior } \\
\text { Partition }\end{array}$} & Gypsum plaster boards & 0.0125 & & \\
\hline & Gap & 0.089 & & \\
\hline & Gypsum plaster boards & 0.0125 & & \\
\hline
\end{tabular}

For the lighting density, the default value from DB was taken having LED linear control features. Due to limited expertise in the HVAC modelling, the simple fan coil heating and cooling (similar to case study) was assigned. The faculty offices have been considered as one single zone because they all have same functions. 


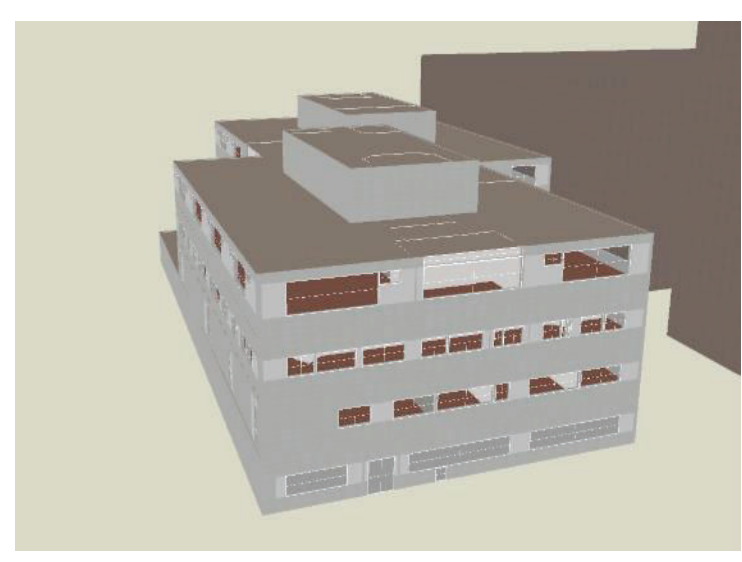

South View

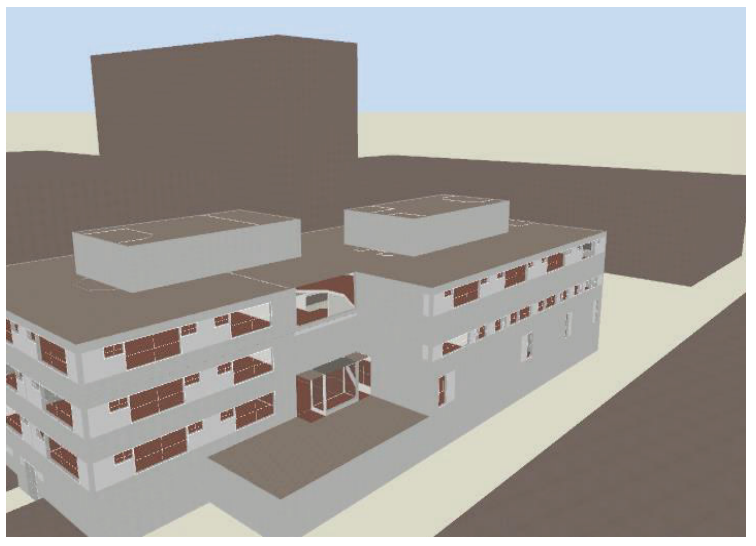

West View

Fig 18: Design Builder image

\subsection{Results of base model and comparison:}

The annual total site energy of the Base model was $1143507.83 \mathrm{kWh}$ and the energy use is $179.77 \mathrm{kWh} / \mathrm{m}^{2}$. Simulation result was compared to the actual energy consumption of the ARC building (Source: Building Science Studio_Winter 2016_Mark \& Umberto) which is $1,055,140.00 \mathrm{kWh}$ (average of the year 2012, 2013, 2014). Though the simulation result shows higher energy consumption by $8.37 \%$ compared to the actual data, it is within the acceptable $20 \%$.

\subsection{Third floor Office area:}

Table 8 includes that the monthly heat gains, heating, cooling and lighting demand of the third floor office area. Solar heat gains is lowest during November-December (4.82 - $5.36 \mathrm{kWh} / \mathrm{m}^{2}$ ) which gradually increases from January displaying the highest experience during September $\left(10.74 \mathrm{kWh} / \mathrm{m}^{2}\right)$. The lighting energy consumption is less during summer (June, July, August) and higher during winter months (NovemberDecember-January). Similarly the demand for space heating starts from September. 
Gradually the heating demand in October rises to $5.84 \mathrm{kWh} / \mathrm{m}^{2}$, reaching the highest in January $\left(24.79 \mathrm{kWh} / \mathrm{m}^{2}\right)$ and ends in May. The duration of space cooling demand is lesser than the space heating. Cooling demand starts from May reaching the maximum in July $\left(10.10 \mathrm{kWh} / \mathrm{m}^{2}\right)$ followed by August. The result also shows the annual solar heat gains due to external windows is $105.21 \mathrm{kWh} / \mathrm{m}^{2}$ and the annual lighting demand is $6.26 \mathrm{kWh} / \mathrm{m}^{2}$. Similarly, the annual heating and cooling demand for the office area are $113.9 \mathrm{kWh} / \mathrm{m}^{2}$ and $23.67 \mathrm{kWh} / \mathrm{m}^{2}$ respectively. The results of base model for Faculty office area are given below:

Table 8: Faculty Office Base Model Energy Demand

\begin{tabular}{|c|c|c|c|c|c|c|c|c|c|c|c|c|}
\hline $\mathrm{kWh} / \mathrm{m}^{2}$ & Jan & Feb & Mar & Apr & May & Jun & Jul & Aug & Sept & Oct & Nov & Dec \\
\hline Heat & & & & & & & & & & & & \\
\hline Gains & 7.45 & 8.16 & 9.35 & 9.70 & 9.86 & 9.89 & 10.28 & 10.69 & 10.74 & 8.87 & 4.82 & 5.36 \\
\hline Lighting & 0.77 & 0.67 & 0.57 & 0.37 & 0.35 & 0.23 & 0.25 & 0.28 & 0.35 & 0.61 & 0.91 & 0.89 \\
\hline Heating & 24.79 & 20.5 & 15.67 & 8.39 & 3.32 & 0.00 & 0.00 & 0.00 & 0.54 & 5.84 & 12.82 & 22.05 \\
\hline Cooling & 0.00 & 0.00 & 0.00 & 0.00 & 0.32 & 3.9 & 10.10 & 7.05 & 2.28 & 0.00 & 0.00 & 0.00 \\
\hline
\end{tabular}

Similarly, Table 9 contains the monthly electricity demand for lighting and computer expressed kWh units. It can be easier to compare to the electricity produced by BIPV against the demand on a monthly basis at later stage of calculation. The yearly electricity demand for lighting and computers are $1194.81 \mathrm{kWh}$ and $5358.85 \mathrm{kWh}$ respectively.

Table 9: Base Model energy demand for lighting and computers

\begin{tabular}{l|c|c|c|c|c|c|c|c|c|c|c|c}
\hline kWh & Jan & Feb & Mar & Apr & May & Jun & Jul & Aug & Sept & Oct & Nov & Dec \\
\hline Lighting & 147.6 & 129.2 & 109.3 & 70.71 & 67.16 & 38.71 & 47.49 & 53.9 & 67.72 & 117.9 & 175.1 & 169.7 \\
\hline Computers & 365.6 & 405.1 & 425.4 & 474.1 & 531.4 & 462.1 & 531.4 & 508.3 & 439.6 & 465.9 & 425.4 & 324.1 \\
\hline
\end{tabular}




\subsection{Results of BIPV application:}

The impact of BIPV was observed under 5 different situations. This was attempted to understand how it impacts the different aspects like solar heat gains and the change in heating, cooling and lighting energy demand. The amount of electricity generation is compared with the annual as well as monthly demand for lighting and combined (lighting and computer). In all the 5 different situations, the base model remains the same but the application of BIPV differs in each case. Given below are the 5 different cases.

\subsubsection{Case 1: Full BIPV on South and West}

In Case 1, the BIPV has been applied to the windows on the south and west. Assumption is made that it is allowed to trim the top portion of the existing trees to get rid of the shadow cast on BIPV windows. The figure shows that solar heat gains rises from May to August reaching the maximum during July while November and December have the lowest heat gains. The total annual solar heat gains is 23.43 $\mathrm{kWh} / \mathrm{m}^{2}$ which is relatively very less compared to the base model.

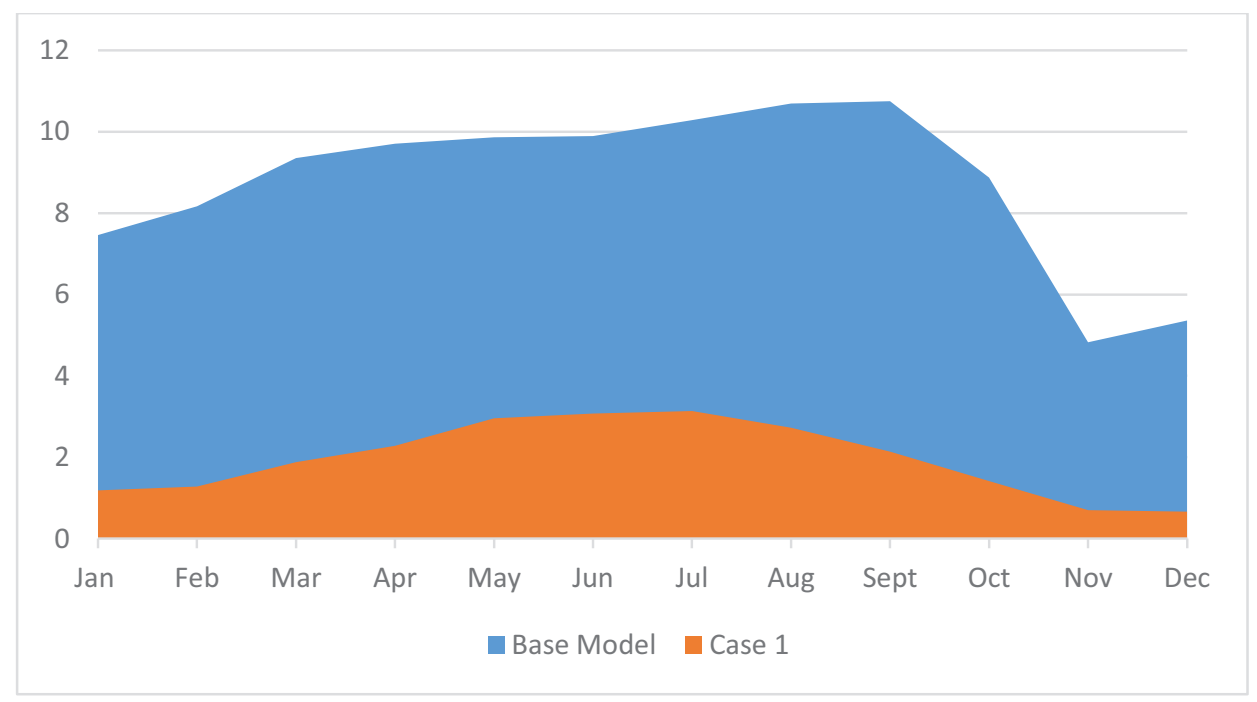

Fig 19: Case 1 vs Base Model - Monthly Solar Heat Gains $\left(\mathrm{kWh} / \mathrm{m}^{2}\right)$ 
Similarly the figure 20 shows the monthly trend of heating, cooling and lighting compared to base model. As a result, the annual heating and cooling demand are 130. $24 \mathrm{kWh} / \mathrm{m}^{2}$ and $18.24 \mathrm{kWh} / \mathrm{m} 2$ which are $12.48 \%$ higher and $23 \%$ less than base model respectively. Also the annual lighting demand is $8.58 \mathrm{kWh} / \mathrm{m}^{2}$ which is around $37 \%$ higher than base model.

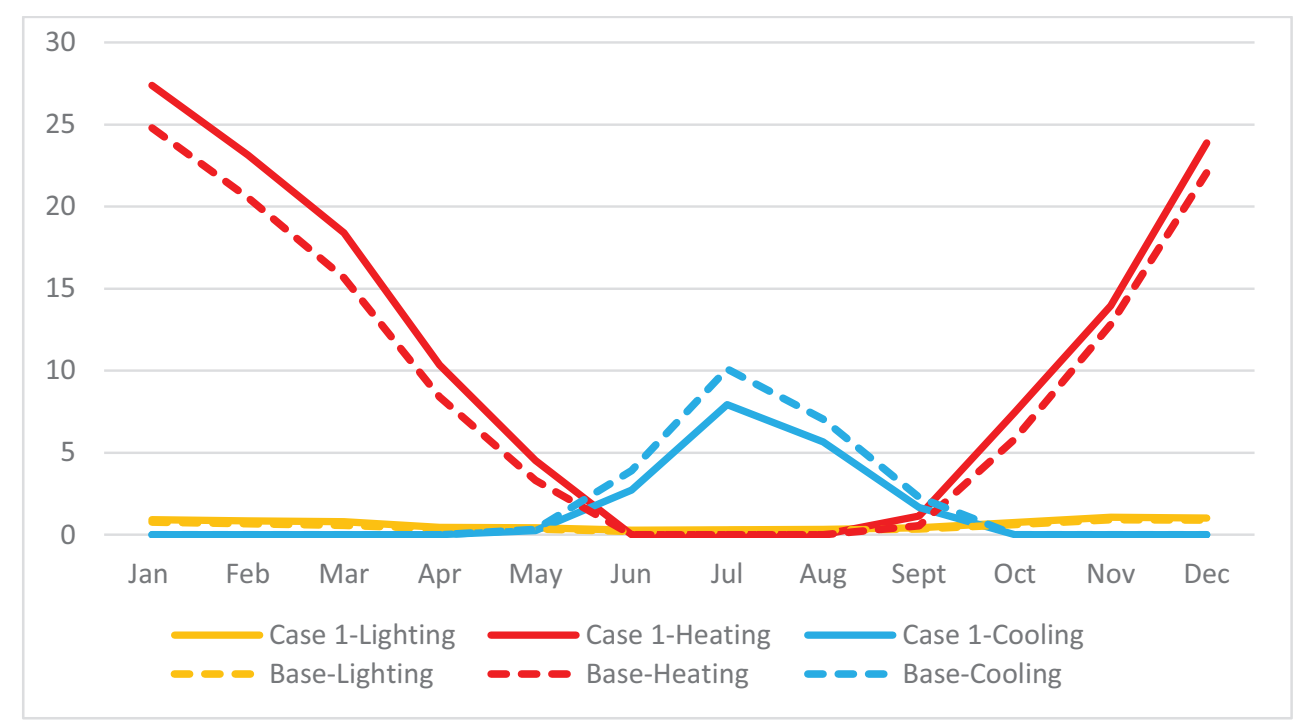

Fig 20: Case 1 vs Base Model - Monthly Heating, Cooling, Lighting Energy $\left(\mathrm{kWh} / \mathrm{m}^{2}\right)$

Table 10 shows the monthly breakdown of the primary energy and solar heat gains of the faculty office area. Contrast to the base model, the highest heat gains is during July. With the use of BIPV, there is an obstruction to the daylight access resulting to increase in lighting demand.

Table 10: Case 1-Monthly Heating, Cooling, Lighting and Heat Gains

\begin{tabular}{l|r|r|r|r|r|r|r|r|r|r|r|r}
\hline $\mathbf{k W h} / \mathbf{m}^{2}$ & \multicolumn{1}{|c|}{ Jan } & \multicolumn{1}{|c|}{ Feb } & \multicolumn{1}{c|}{ Mar } & \multicolumn{1}{c|}{ Apr } & \multicolumn{1}{|c|}{ May } & \multicolumn{1}{c}{ Jun } & Jul & \multicolumn{1}{c|}{ Aug } & Sept & Oct & Nov & Dec \\
\hline Heat Gains & 1.18 & 1.28 & 1.88 & 2.28 & 2.95 & 3.07 & 3.13 & 2.72 & 2.13 & 1.41 & 0.70 & 0.66 \\
\hline Lighting & 0.95 & 0.87 & 0.90 & 0.67 & 0.62 & 0.45 & 0.40 & 0.45 & 0.54 & 0.74 & 0.97 & 1.02 \\
\hline Heating & 27.38 & 23.13 & 18.39 & 10.36 & 4.52 & 0.0 & 0.0 & 0.0 & 1.141 & 7.45 & 13.9 & 23.8 \\
\hline Cooling & 0.0 & 0.0 & 0.0 & 0.0 & 0.26 & 2.71 & 7.93 & 5.66 & 1.66 & 0.0 & 0.0 & 0.0 \\
\hline
\end{tabular}




\subsubsection{Electricity Generation:}

The annual electricity generation capacity of BIPV is $8030 \mathrm{kWh}$. Table 11 shows electricity production gradually increases from $530 \mathrm{kWh}$ in January to $850 \mathrm{kWh}$ in July. Then the production is declines during October, November and December. Similarly, the annual electricity demand for lighting and computer are $1424.8 \mathrm{kWh}$ and $5358.85 \mathrm{kWh}$.

Table 11: Case 1-BIPV electricity vs lighting and computer electricity demand

\begin{tabular}{l|r|r|r|r|r|r|r|r|r|r|r|r}
\hline kWh & \multicolumn{1}{|c|}{ Jan } & \multicolumn{1}{|c|}{ Feb } & \multicolumn{1}{|c|}{ Mar } & \multicolumn{1}{c|}{ Apr } & \multicolumn{1}{c|}{ May } & \multicolumn{1}{c|}{ Jun } & \multicolumn{1}{c|}{ Jul } & Aug & Sept & Oct & Nov & Dec \\
\hline BIPV & & & & & & & & & & & & \\
Electricity & 530 & 590 & 690 & 750 & 790 & 810 & 850 & 840 & 800 & 650 & 350 & 380 \\
\hline Lighting & 175.4 & 160.1 & 122.2 & 87.9 & 82.0 & 51.49 & 59.1 & 63.0 & 82.0 & 141.2 & 206.0 & 194.5 \\
\hline Computer & 365.6 & 405.1 & 425.4 & 474.1 & 531.4 & 462.1 & 531.4 & 508.3 & 439.6 & 465.9 & 425.4 & 324.1 \\
\hline
\end{tabular}

Figure 21 shows that the comparison between the monthly production capacity of BIPV with the demand. The result shows that the BIPV has more than required capacity to fulfill the energy demand for lighting the office area throughout the year even during November and December, when the production is low. BIPV can also fulfill $100 \%$ to the combined (lighting + computers) energy demand of the office from February to October and more than $90 \%$ in January. Even during November and December, the BIPV can generate electricity to fulfill more than $50 \%$ of combined lighting + computer demand. 


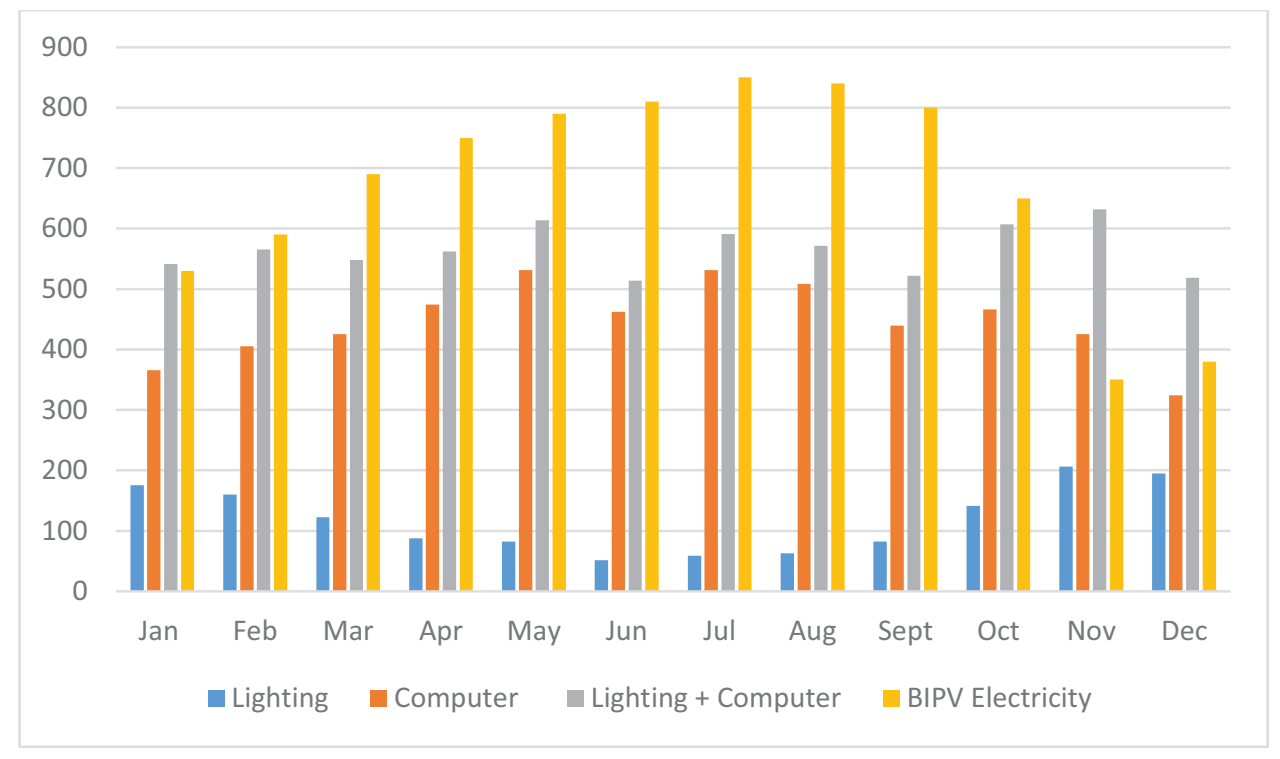

Fig 21: Case 1 BIPV vs Monthly electricity demand (kWh)

\subsubsection{Case 2: BIPV on West windows only}

If the City of Toronto does not allow to trim the existing trees, it will not be a wise strategy to have BIPV windows on south façade. So, in Case 2, the impact of the BIPV window on the south west façade is analyzed is only used on the west windows. The annual solar heat gains $=68.84 \mathrm{kWh} / \mathrm{m}^{2}$ which is around $65 \%$ less compared to base model without BIPV.

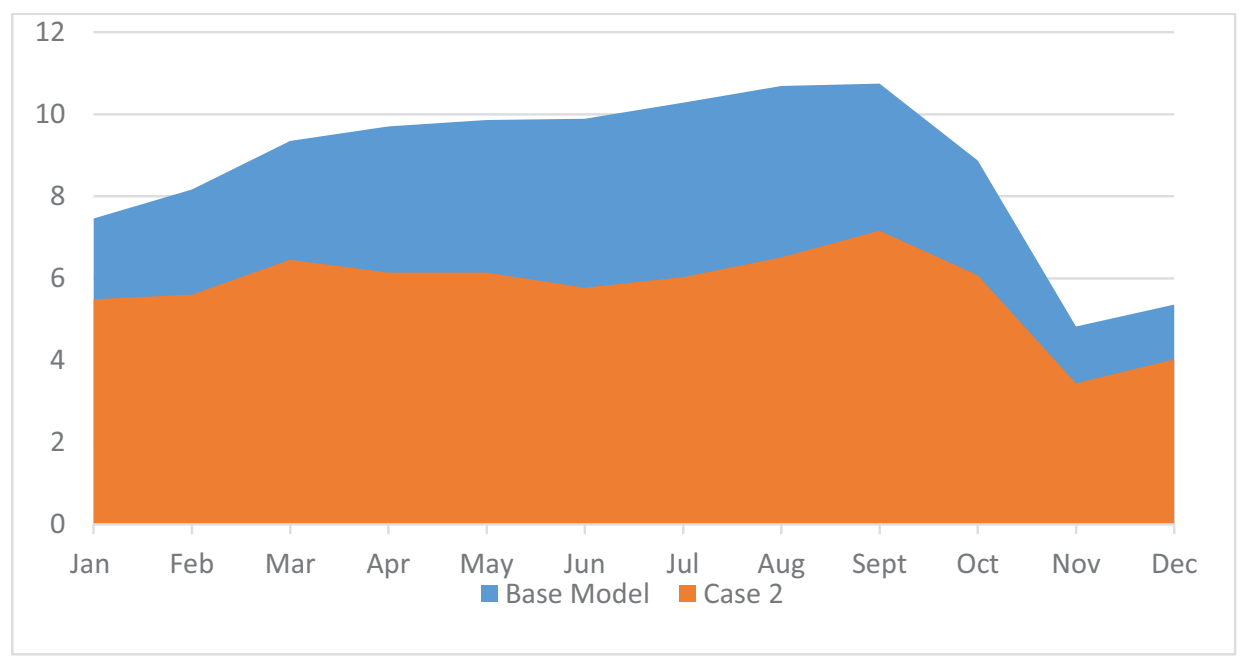

Fig 22: Case 2 vs Base Model - Monthly Solar Heat Gains $\left(\mathrm{kWh} / \mathrm{m}^{2}\right)$ 
Figure 23 shows the overall changes in the heating, cooling and lighting demand when BIPV is used only towards the west oriented windows. Consequently, the annual heating and cooling demand are $120.60 \mathrm{kWh} / \mathrm{m}^{2}$ and $20.14 \mathrm{kWh} / \mathrm{m}^{2}$ which are $5.7 \%$ higher and $15 \%$ less than base model respectively. Similarly, the annual lighting demand is $6.98 \mathrm{kWh} / \mathrm{m}^{2}$ which is around $11 \%$ higher than base model.

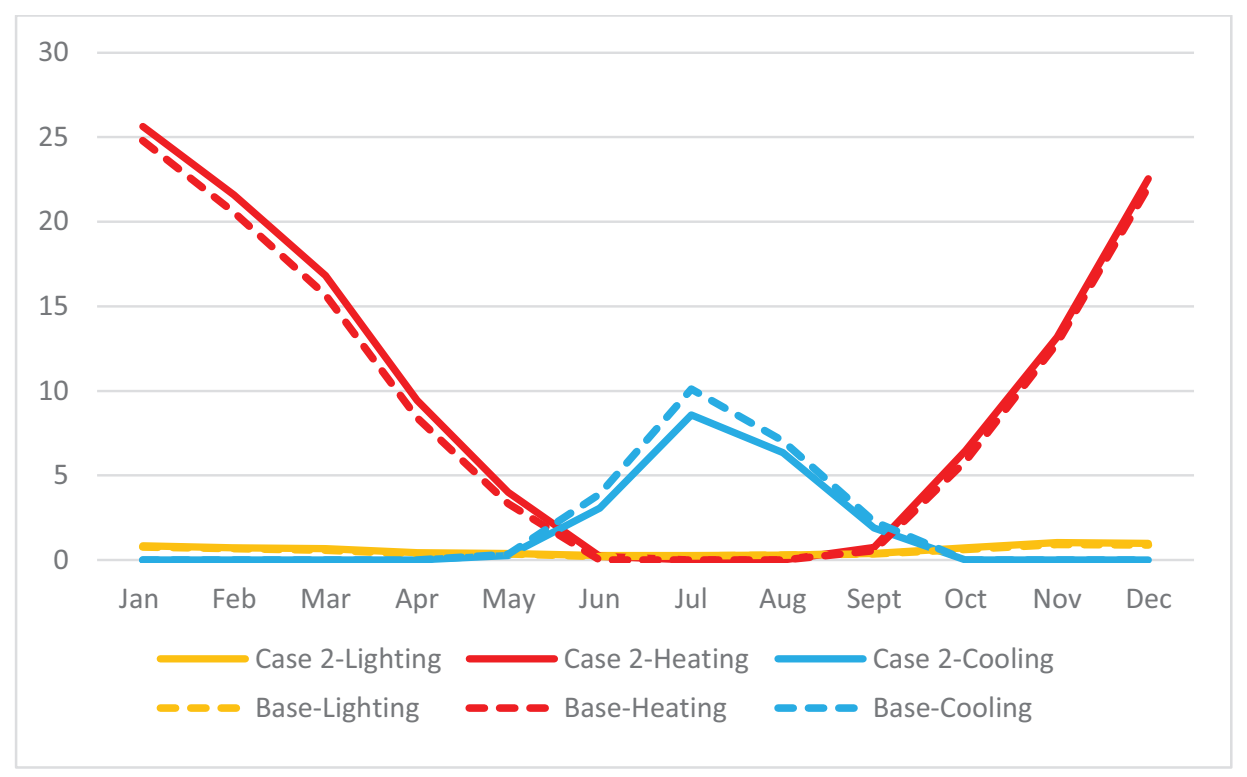

Fig 23: Case 2 vs Base Model - Monthly Heating, Cooling, Lighting Energy $\left(\mathrm{kWh} / \mathrm{m}^{2}\right)$

Table 12 shows the monthly breakdown of the primary energy and solar heat gains of the faculty office area. September followed by March experiences the highest while the November-December has least heat gains. It also shows the heating demand are maximum during December-January-February and the cooling is maximum in July followed by August. On the other hand, the lighting energy demand is lesser than Case 1 but higher that the base model. 
Table 12: Case 2-Monthly Heating, Cooling, Lighting and Heat Gains $\left(\mathrm{kWh} / \mathrm{m}^{2}\right)$

\begin{tabular}{|c|c|c|c|c|c|c|c|c|c|c|c|c|}
\hline $\mathrm{kWh} / \mathrm{m}^{2}$ & Jan & Feb & Mar & Apr & May & Jun & Jul & Aug & Sept & Oct & Nov & Dec \\
\hline Heat Gains & 5.49 & 5.60 & 6.45 & 6.14 & 6.14 & 5.77 & 6.03 & 6.51 & 7.16 & 6.07 & 3.44 & 4.02 \\
\hline Lighting & 0.85 & 0.712 & 0.671 & 0.431 & 0.382 & 0.271 & 0.261 & 0.301 & 0.382 & 0.724 & 1.02 & 0.98 \\
\hline Heatir & 25.63 & 21.57 & 16.80 & 9.44 & 4.00 & 0.21 & 0.00 & 0.00 & 0.73 & 6.47 & 13.17 & 22.54 \\
\hline Cooling & 0.0 & 0.0 & 0.0 & 0.0 & 0.27 & 3.06 & 8.57 & 6.33 & 1.89 & 0.0 & 0.0 & 0.0 \\
\hline
\end{tabular}

\subsubsection{Electricity Generation:}

The annual electricity generation capacity of BIPV is $4340 \mathrm{kWh}$ which is $46 \%$ less compared to Case 1 . Table 13 shows electricity production gradually increases from $240 \mathrm{kWh}$ in January to $520 \mathrm{kWh}$ in July. Then the production is declines during October, November and December. The annual electricity demand for lighting and computer are $1337.63 \mathrm{kWh}$ and 5358.85 kWh.

Table 13: Case 2-BIPV electricity vs lighting and computer electricity demand

\begin{tabular}{l|c|c|c|c|c|c|c|c|c|c|c|c}
\hline kWh & Jan & Feb & Mar & Apr & May & Jun & Jul & Aug & Sept & Oct & Nov & Dec \\
\hline BIPV & & & & & & & & & & & & \\
Electricity & 240 & 290 & 340 & 420 & 470 & 510 & 520 & 500 & 410 & 320 & 160 & 160 \\
\hline Lighting & 162.0 & 135.7 & 128 & 87.2 & 72.88 & 51.68 & 49.78 & 57.53 & 72.89 & 138.1 & 194.6 & 186.9 \\
\hline Computer & 365.6 & 405.1 & 425.4 & 474.1 & 531.4 & 462.1 & 531.4 & 508.3 & 439.6 & 465.9 & 425.4 & 324.1 \\
\hline
\end{tabular}

Figure 24 shows that the comparison between the monthly production capacity of BIPV with the demand. In this case also, the BIPV can fulfill $100 \%$ of the lighting electricity demand from January to October and above $80 \%$ for November and December. For the combined (lighting + computers) energy demand of the office, BIPV window can fulfill more than $70 \%$ from April to September. For the rest of the months also, BIPV can supply more than $25 \%$ of the combined energy demand. 


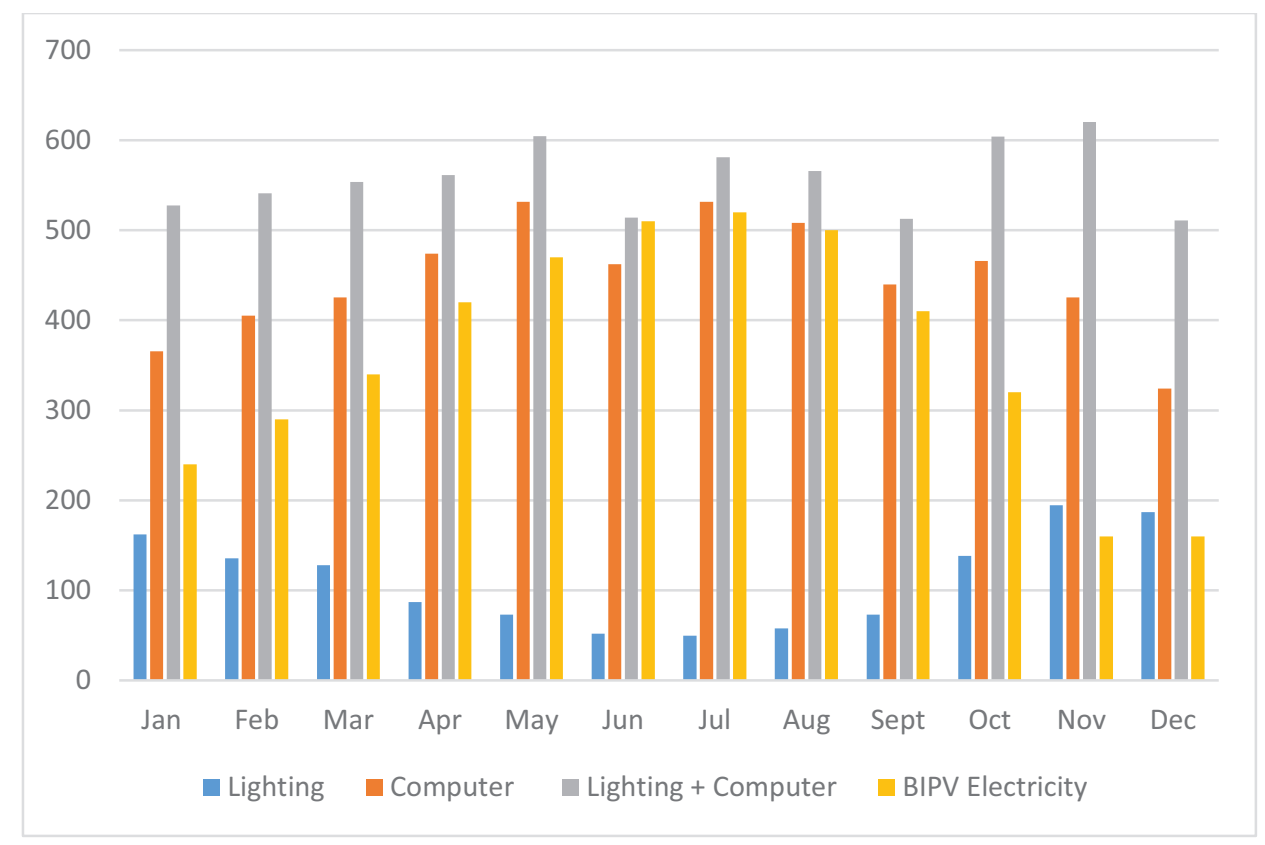

Fig 24: Case 2 BIPV vs Monthly electricity demand (kWh)

\subsubsection{Case 3: BIPV on the lower half of West windows only}

Case 3 is the combination of base model and Case 2, where only the bottom part of the window on the west will be converted to BIPV. Applying BIPV window at the lower half of the window will allow to control glare on working surface close to window and still allow to transmit lights from above. The overall annual solar heat gains is similar to the base model with some marginal difference (Figure 25). The reason is that the percentage of BIPV window has been reduced substantially and there are large percentage of transparent windows exposed to direct sunlight. 


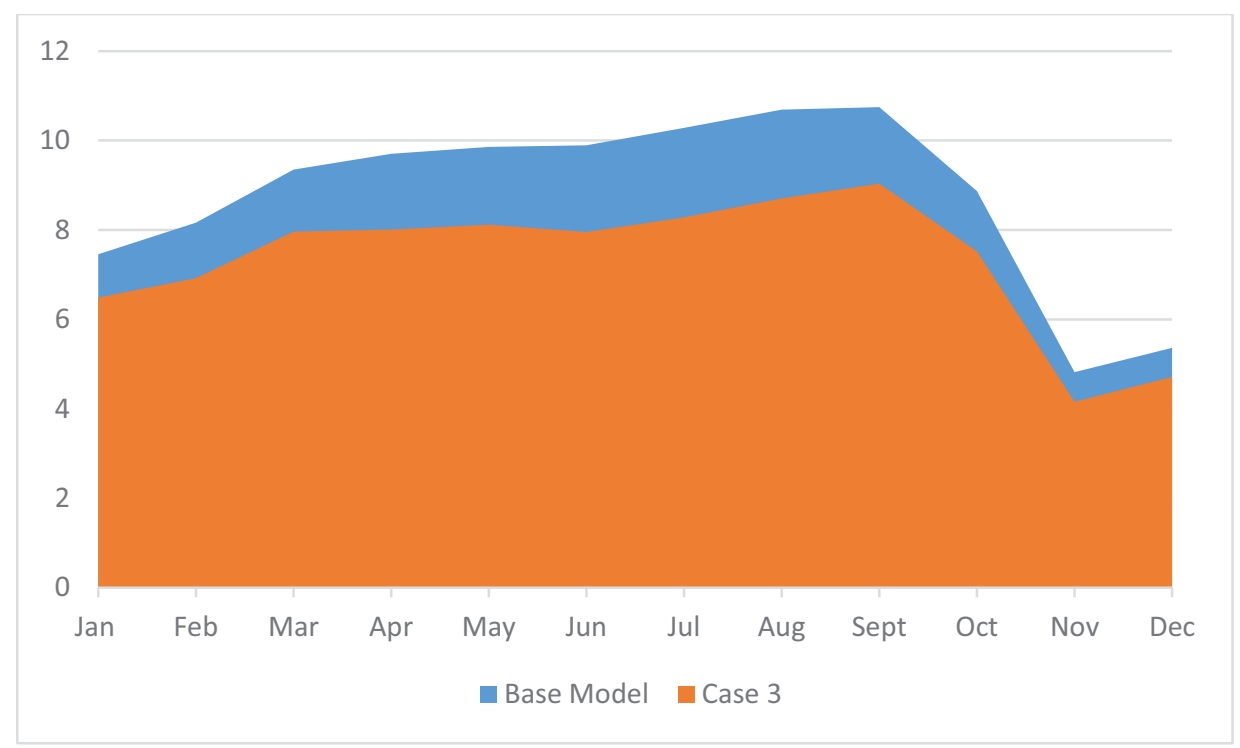

Fig 25: Case 3 vs Base Model - Monthly Solar Heat Gains $\left(\mathrm{kWh} / \mathrm{m}^{2}\right)$

Figure 26 shows the overall changes in the heating, cooling and lighting demand when BIPV is used only on the lower half of the south west oriented windows. This option also features the maximum use of the transparent glass, making it similar to Case 1. Consequently, the annual heating and cooling demand are 117.34 $\mathrm{kWh} / \mathrm{m}^{2}$ and $22.00 \mathrm{kWh} / \mathrm{m}^{2}$ which are $3 \%$ higher and $7 \%$ less than base model respectively.

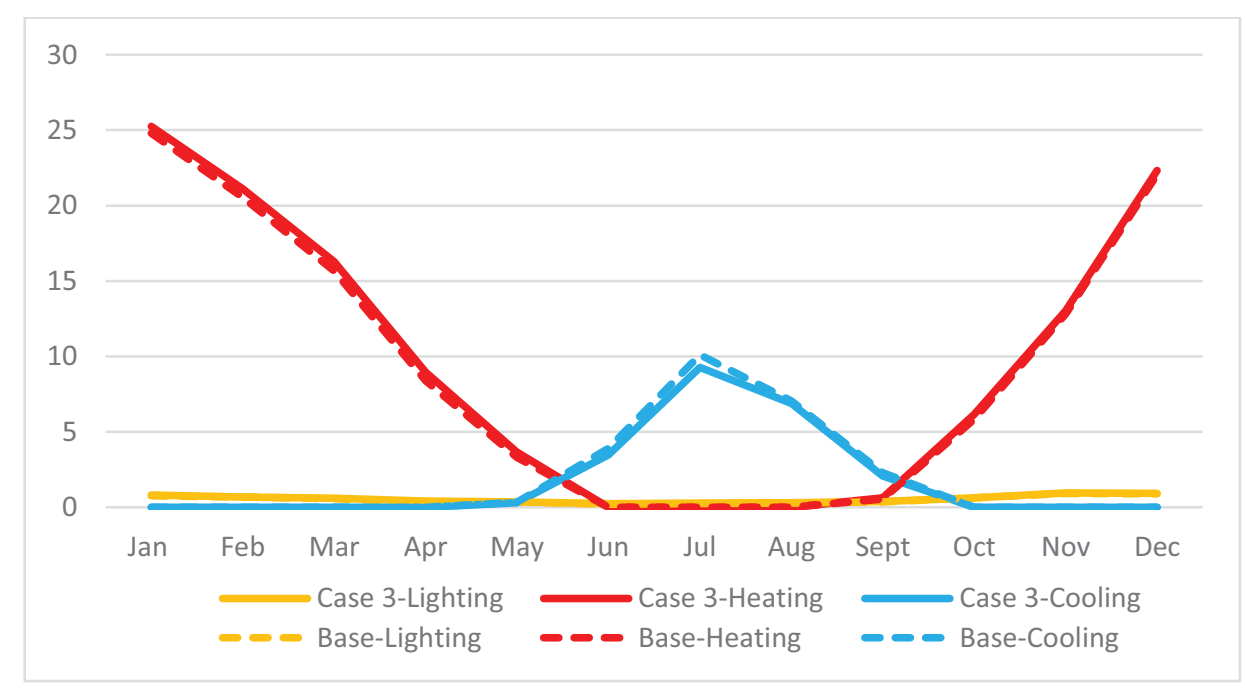

Figure 26: Case 3 vs Base Model - Monthly Heating, Cooling, Lighting Energy $\left(\mathrm{kWh} / \mathrm{m}^{2}\right)$ 
Table 14 shows the monthly breakdown of the primary energy demand and solar heat gains of the faculty office area. In this case, the solar heat remains consistently at higher level except in November-December. The peak cooling demand can be seen during July and August. Whereas there is a longer and higher heating demand starting from October till May. But the demand for the lighting energy seems to decline.

Table 14: Case 3- Monthly Heating, Cooling, Lighting and Heat Gains $\left(\mathrm{kWh} / \mathrm{m}^{2}\right)$

\begin{tabular}{|c|c|c|c|c|c|c|c|c|c|c|c|c|}
\hline $\mathrm{kWh} / \mathrm{m}^{2}$ & Jan & Feb & Mar & Apr & May & Jun & Jul & Aug & Sept & Oct & Nov & Dec \\
\hline Heat Gains & 6.49 & 6.92 & 7.96 & 8.00 & 8.11 & 7.95 & 8.28 & 8.70 & 9.03 & 7.52 & 4.15 & 4.71 \\
\hline Lighting & 0.82 & 0.69 & 0.59 & 0.4 & 0.37 & 0.24 & 0.27 & 0.316 & 0.38 & 0.64 & 0.95 & 0.91 \\
\hline Heating & 25.24 & 21.11 & 16.29 & 8.94 & 3.66 & 0.00 & 0.00 & 0.00 & 0.63 & 6.16 & 13.04 & 22.33 \\
\hline Cooling & 0.0 & 0.0 & 0.0 & 0.0 & 0.29 & 3.47 & 9.27 & 6.88 & 2.07 & 0.0 & 0.0 & 0.0 \\
\hline
\end{tabular}

\subsubsection{Electricity Generation:}

The annual electricity generation capacity of BIPV is $2310 \mathrm{kWh}$ which is $71 \%$ less compared to Case1. Whereas the annual electricity demand for lighting is $1296.61 \mathrm{kWh}$ which is only $56 \%$ of the BIPV capacity. Alongside the decrease in electricity production, the lighting energy demand also goes down because of the lower BIPV window percentage compared to the transparent window.

Table 15: Case 3-BIPV electricity vs lighting and computer electricity demand (kWh)

\begin{tabular}{l|c|c|c|c|c|c|c|c|c|c|c|c}
\hline kWh & Jan & Feb & Mar & Apr & May & Jun & Jul & Aug & Sept & Oct & Nov & Dec \\
\hline BIPV & & & & & & & & & & & & \\
Electricity & 130 & 160 & 180 & 220 & 250 & 270 & 280 & 260 & 220 & 170 & 90 & 80 \\
\hline Lighting & 156.4 & 140.0 & 118.6 & 78.0 & 75.4 & 44.8 & 56.5 & 61.7 & 75.5 & 125.8 & 186.5 & 177.0 \\
\hline Computer & 365.6 & 405.1 & 425.4 & 474.1 & 531.4 & 462.1 & 531.4 & 508.3 & 439.6 & 465.9 & 425.4 & 324.1 \\
\hline
\end{tabular}


Figure 27 explains that even in this scenario, where there is only one third of BIPV applied compared to Case 1, the BIPV window generates the surplus electricity from February to October to fulfill the lighting energy demand. It is also impressive to see that BIPV window can still fulfill more that $45 \%$ of the demand for the remaining months.

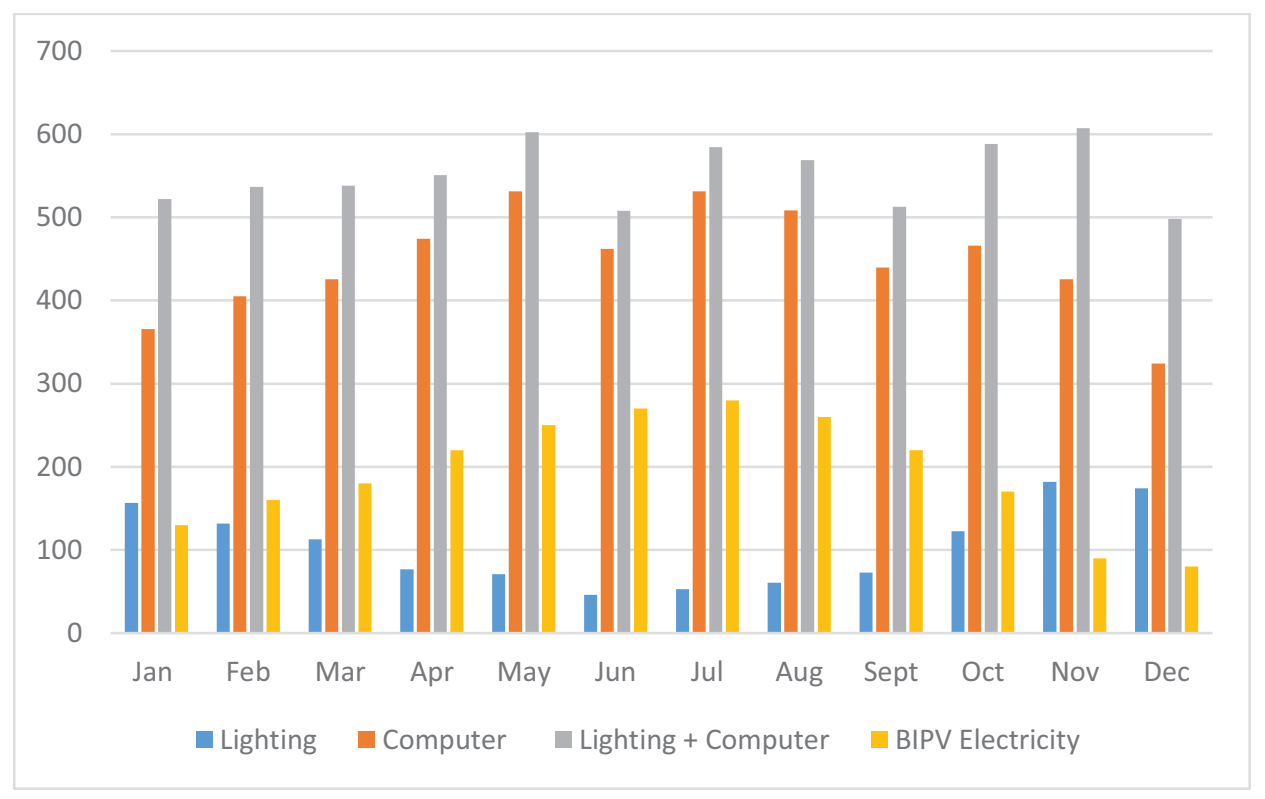

Fig 27: Case 3-BIPV vs Monthly electricity demand (kWh)

\subsubsection{Case 4: BIPV + low-E on South and West windows}

In this example, the low-E window with BIPV has been simulated. Low-E windows plays important role by allowing the short wave infrared energy to pass through the fenestration and reflects the heat back into the enclosed space. This process reduces the heat transfer from the inner to the outer pane that lowers the changes of heat escaping from the window. Thus it contributes to reduction in heating demand which is much desirable in the heating dominant cold climates. Additionally, the low-E glass reduces the amount of ultraviolet and infrared light from passing through the glass minimizing the glare effect but the amount of visual 
light remains uncompromised. Figure 28 shows that the combination of low-E and BIPV has similar heat gains profile compared to the Case 1 where it was a regular transparent glass with BIPV. The annual solar heat gains $=21.28 \mathrm{kWh} / \mathrm{m}^{2}$. Which means it is around $80 \%$ less compared to base model and $10 \%$ less than Case 1.

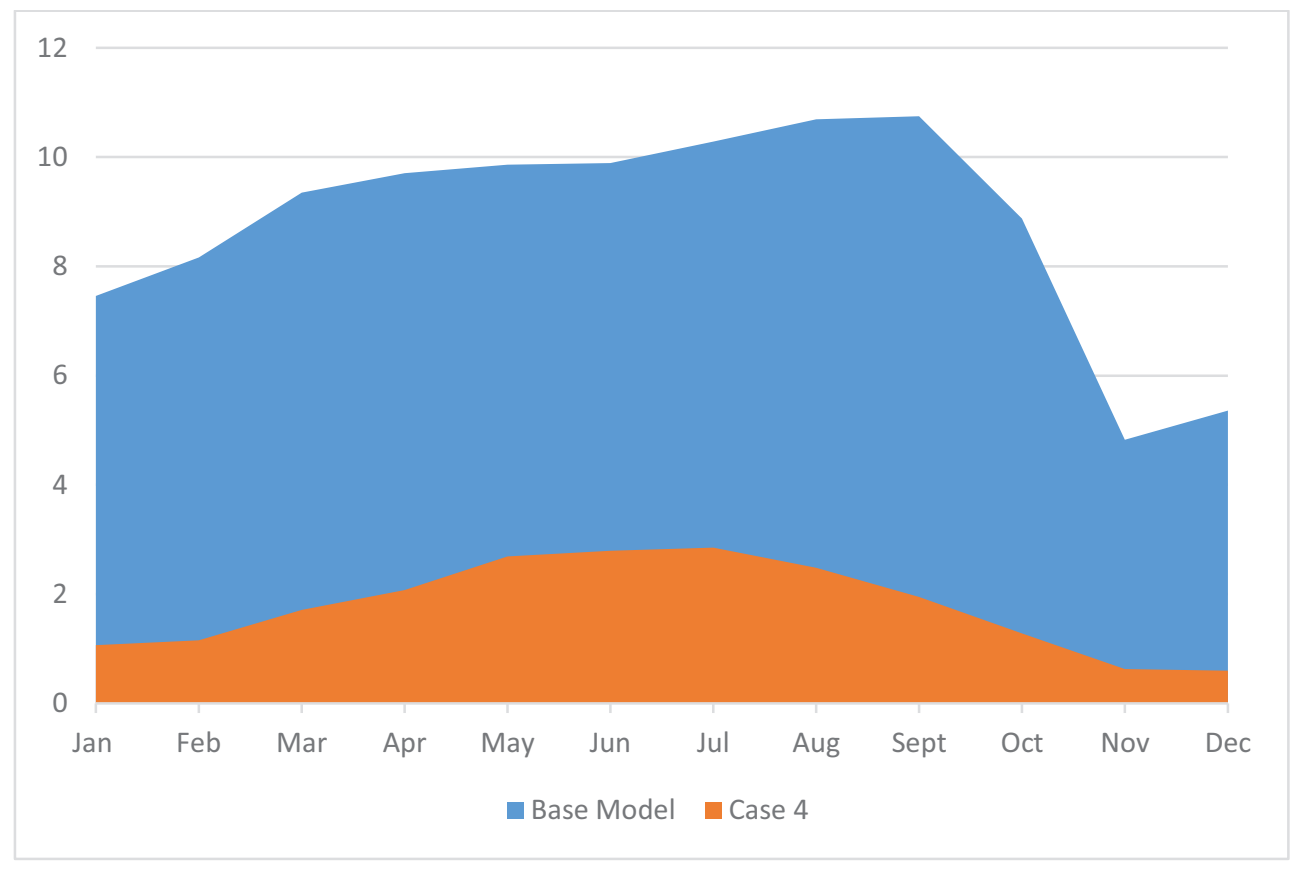

Fig 28: Case 4 vs Base Model - Monthly Solar Heat Gains $\left(\mathrm{kWh} / \mathrm{m}^{2}\right)$

Figure 29 shows the overall changes in the heating, cooling and lighting demand when BIPV + low-E window is used on the south and west windows. The corresponding annual heating and cooling energy demand is $123.43 \mathrm{kWh} / \mathrm{m}^{2}$ and $17.7 \mathrm{kWh} / \mathrm{m}^{2}$ respectively. Compared to base model, there is an increase in heating and lighting demand by $8 \%$ and $29 \%$ respectively. Whereas the cooling demand decreased by $25 \%$. Similarly, compared to Case 1 , there was minor decrease in heating and cooling demand by $5 \%$ and $3 \%$ respectively. 


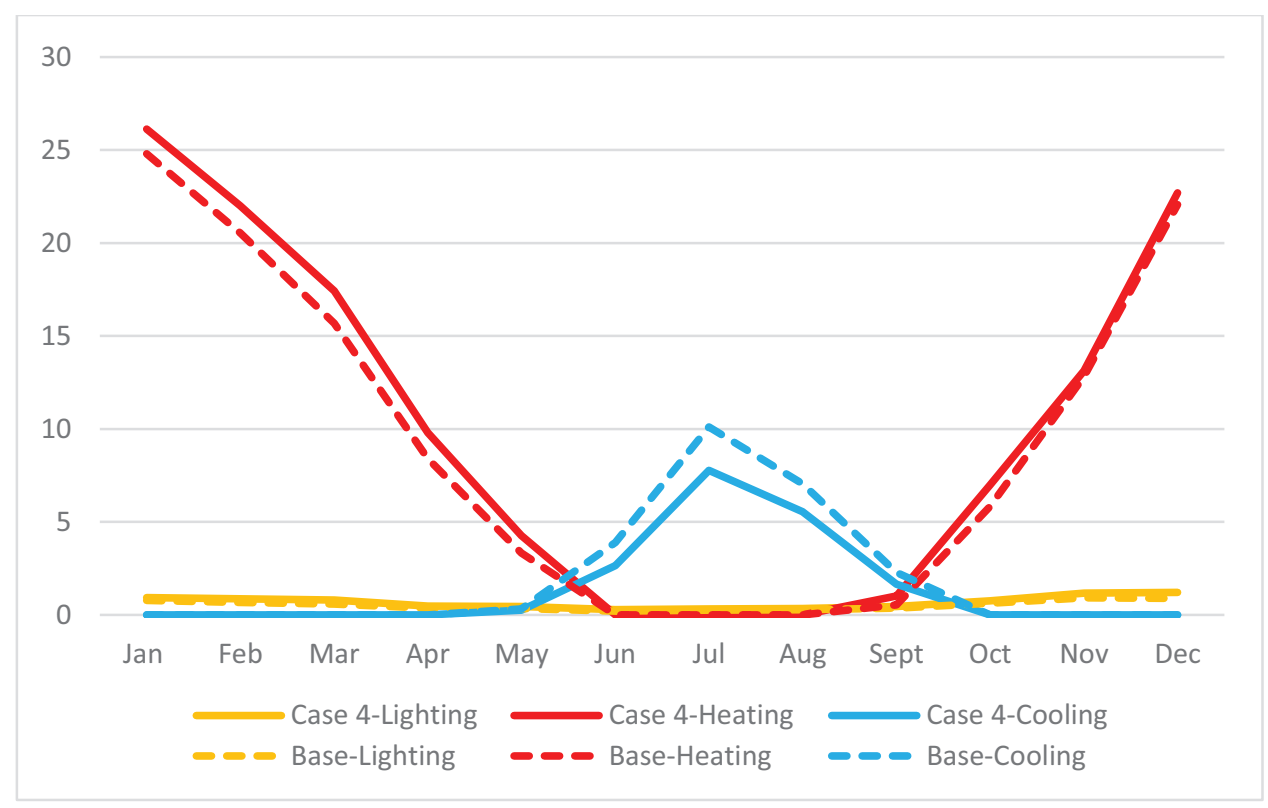

Fig 29: Case 4 vs Base Model - Monthly Heating, Cooling, Lighting Energy $\left(\mathrm{kWh} / \mathrm{m}^{2}\right)$

Table 16 shows the monthly breakdown of the primary energy demand and solar heat gains of the faculty office area. The result exhibits the similar heat gains and primary energy demand compared to Case 1 with overall minor variations. In this case, the solar heat gains in December is the lowest, which gradually increases to the highest during July. Similarly, the heating demand is maximum from December to February. And the maximum cooling demand is during July and August. Lighting demand is highest from November to January and lowest during June.

Table 16: Case 4- Monthly Heating, Cooling, Lighting and Heat Gains $\left(\mathrm{kWh} / \mathrm{m}^{2}\right)$

\begin{tabular}{l|r|r|r|r|r|r|r|r|r|r|r|r}
\hline $\mathbf{k W h} / \mathbf{m}^{2}$ & \multicolumn{1}{|c|}{ Jan } & \multicolumn{1}{|c|}{ Feb } & Mar & \multicolumn{1}{|c|}{ Apr } & May & Jun & Jul & Aug & Sept & Oct & Nov & Dec \\
\hline Heat Gains & 1.06 & 1.15 & 1.71 & 2.07 & 2.69 & 2.79 & 2.85 & 2.48 & 1.95 & 1.28 & 0.63 & 0.56 \\
\hline Lighting & 0.94 & 0.86 & 0.805 & 0.48 & 0.45 & 0.283 & 0.32 & 0.35 & 0.45 & 0.76 & 1.18 & 1.21 \\
\hline Heating & 26.12 & 21.98 & 17.41 & 9.79 & 4.25 & 0.00 & 0.00 & 0.00 & 1.02 & 6.99 & 13.14 & 22.69 \\
\hline Cooling & 0.0 & 0.0 & 0.0 & 0.0 & 0.26 & 2.64 & 7.77 & 5.55 & 1.64 & 0.0 & 0.0 & 0.0 \\
\hline
\end{tabular}




\subsubsection{Electricity Generation:}

The annual energy demand for lighting and computers are $3749.44 \mathrm{kWh}$ and 5358.85 kWh respectively. Similar to Case 1, the low-E featured BIPV can generate $8030 \mathrm{kWh}$ electricity annually. This means that BIPV can fulfill around $88 \%$ of the combined annual energy demand for lighting and computers.

Table 17: Case 4- Monthly electrical demand vs supply (kWh)

\begin{tabular}{l|c|c|c|c|c|c|c|c|c|c|c|c}
\hline kWh & Jan & Feb & Mar & Apr & May & Jun & Jul & Aug & Sept & Oct & Nov & Dec \\
\hline BIPV & & & & & & & & & & & & \\
Electricity & 530 & 590 & 690 & 750 & 790 & 810 & 850 & 840 & 800 & 650 & 350 & 380 \\
\hline Lighting & 179.2 & 163.9 & 153.6 & 91.92 & 87.19 & 53.96 & 62.17 & 67.08 & 86.79 & 145.5 & 225.16 & 230.82 \\
\hline Computer & 365.6 & 405.1 & 425.4 & 474.1 & 531.4 & 462.1 & 531.4 & 508.3 & 439.6 & 465.9 & 425.4 & 324.1 \\
\hline
\end{tabular}

The BIPV energy generation varies monthly, but the fig 30 shows that it can fulfill the monthly as well as annual lighting energy demand. The result also shows the BIPV can also fulfill $100 \%$ to the combined (lighting + computers) energy demand of the office from February to October, above $90 \%$ during January and more than 50\% November and December.

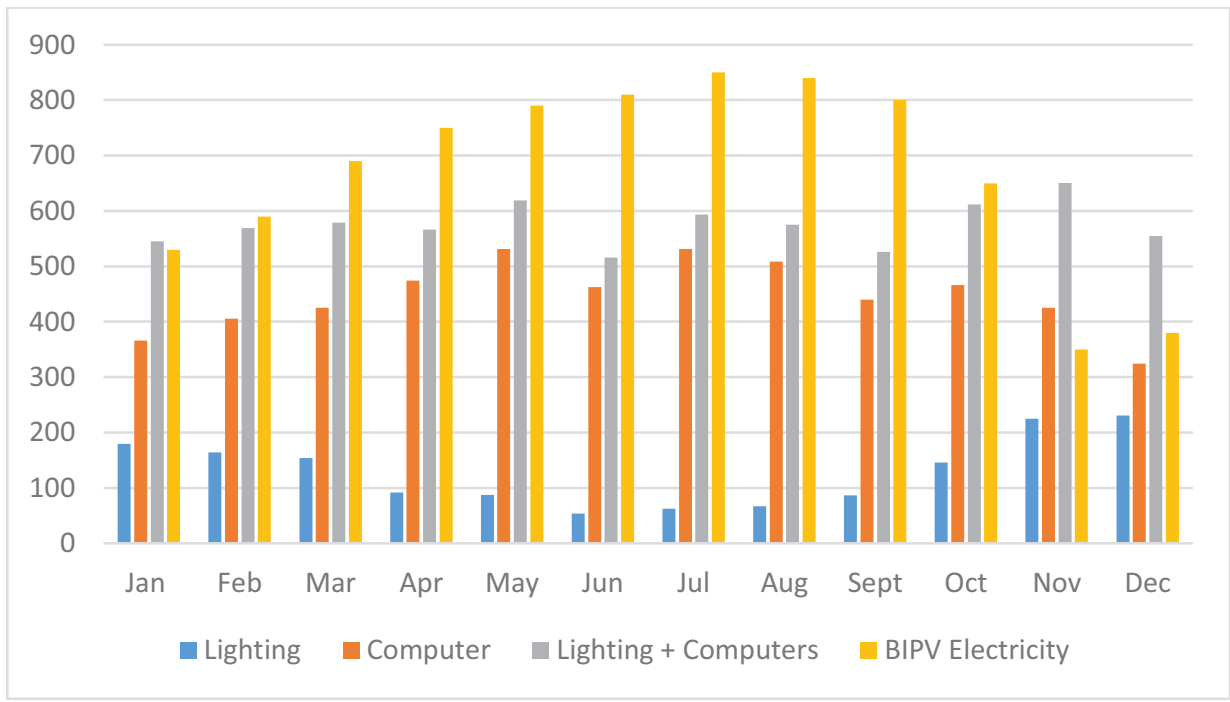

Fig 30: Case 4 BIPV vs Monthly electricity demand (kWh) 


\subsubsection{Case 5: BIPV-lower half of South and West windows}

Case 5 is the combination of base model and Case 3 , where the bottom part of the existing windows (South and West) will be replaced by the BIPV windows. Applying BIPV window at the lower half of the window will allow to control glare on working surface close to window and still allow to transmit lights from above. The result shows that the annual heat gains $=67.50 \mathrm{kWh} / \mathrm{m}^{2}$ which is around $35 \%$ less than base model result.

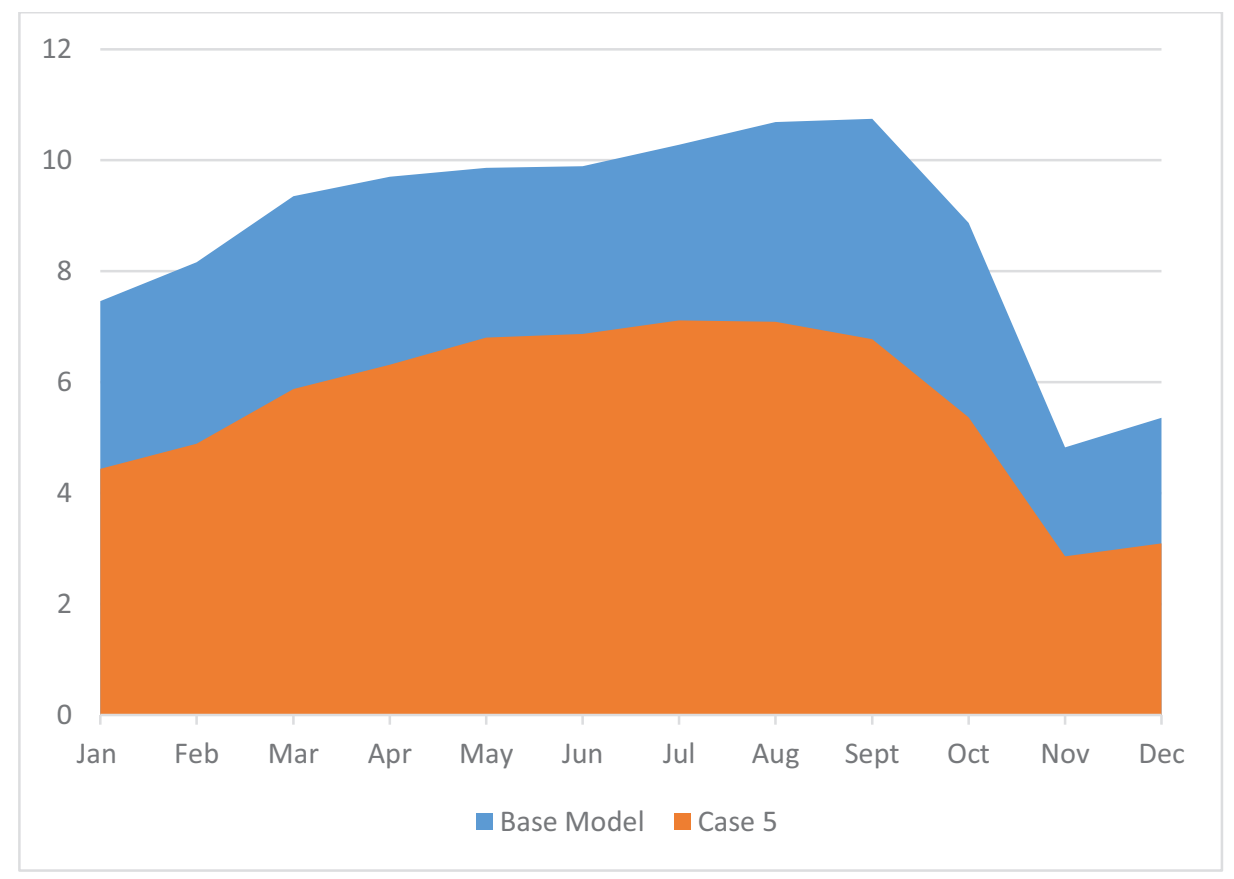

Fig 31: Case 5 vs Base Model - Monthly Solar Heat Gains $\left(\mathrm{kWh} / \mathrm{m}^{2}\right)$

Figure 32 shows the month to month changes in the heating, cooling and lighting demand when BIPV is used only on the lower half on the south west and south east windows. The corresponding annual heating and cooling energy demand is $123.04 \mathrm{kWh} / \mathrm{m}^{2}$ and $20.74 \mathrm{kWh} / \mathrm{m}^{2}$ respectively. Compared to base model, the heating and lighting energy demand increase by $8 \%$ and $10 \%$ respectively whereas the cooling demand decreased by $12 \%$. 


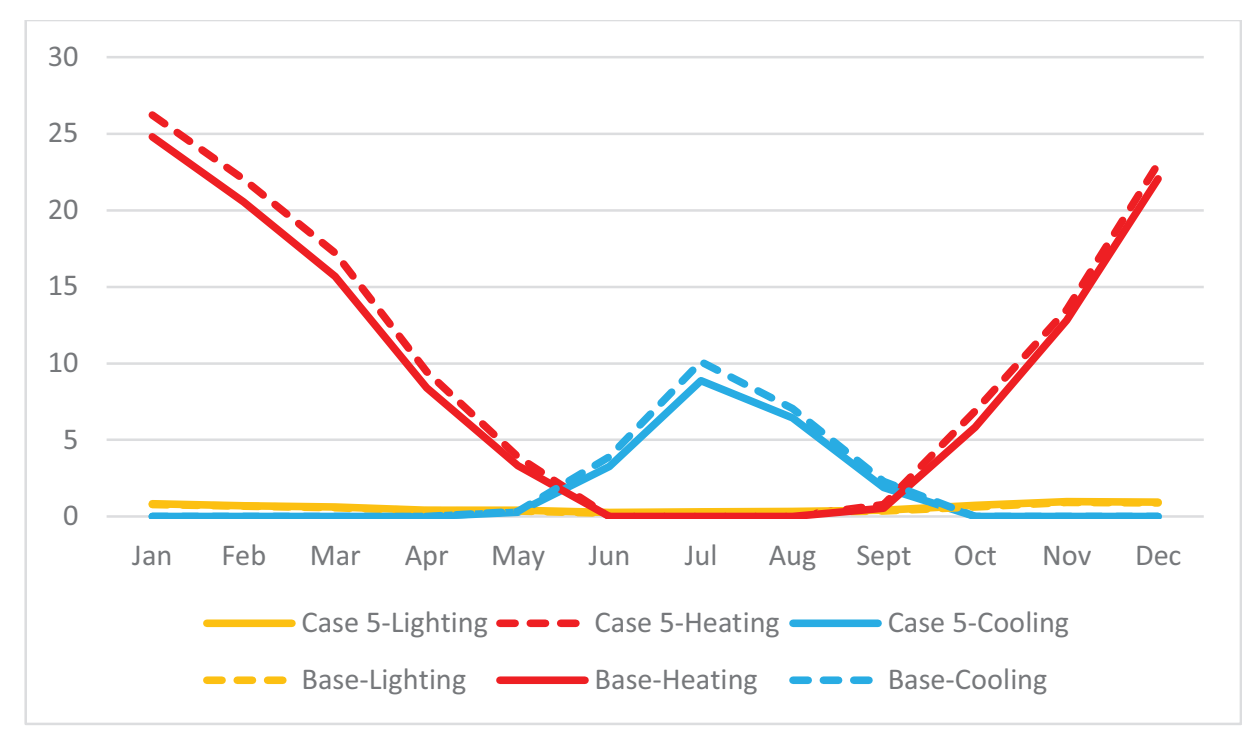

Fig 32: Case 5 vs Base Model - Monthly Heating, Cooling, Lighting Energy $\left(\mathrm{kWh} / \mathrm{m}^{2}\right)$

Table 18 shows the monthly breakdown of the primary energy demand and solar heat gains of the faculty office area. The result shows that there is not a great variation in the monthly solar heat gains from January to September except for November-December where it is comparatively low. The lighting and heating energy demand are higher from November to February corresponding to the outside weather condition.

Table 18: Case 5-Monthly Heating, Cooling, Lighting and Heat Gains $\left(\mathrm{kWh} / \mathrm{m}^{2}\right)$

\begin{tabular}{|c|c|c|c|c|c|c|c|c|c|c|c|c|}
\hline $\mathrm{kWh} / \mathrm{m}^{2}$ & Jan & Feb & Mar & Apr & May & Jun & Jul & Aug & Sept & Oct & Nov & Dec \\
\hline Heat Gains & 4.43 & 4.89 & 5.87 & 6.31 & 6.80 & 6.87 & 7.11 & 7.09 & 6.77 & 5.36 & 2.86 & 3.09 \\
\hline Lighting & 0.83 & 0.71 & 0.62 & 0.415 & 0.398 & 0.262 & 0.294 & 0.322 & 0.397 & 0.732 & 0.971 & 0.947 \\
\hline Heating & 26.2 & 22.0 & 17.2 & 9.47 & 3.9 & 0.0 & 0.0 & 0.0 & 0.77 & 6.88 & 13.5 & 23.0 \\
\hline Cooling & 0.0 & 0.0 & 0.0 & 0.0 & 0.27 & 3.25 & 8.87 & 6.45 & 1.89 & 0.0 & 0.0 & 0.0 \\
\hline
\end{tabular}

\subsubsection{Electricity Generation:}

The annual energy demand for lighting and computers are $1316.13 \mathrm{kWh}$ and $5358.85 \mathrm{kWh}$ respectively. Whereas the annual electricity generation capacity 
of BIPV is $4210 \mathrm{kWh}$ which can fulfill around $63 \%$ of the combined energy demand for lighting and computers annually. Even though the BIPV energy generation varies monthly, the figure below shows that it can generate sufficient electricity except during November where it the supply can fulfill around $92 \%$ of the demand.

Table 19: Case 5- Monthly electrical demand vs supply (kWh)

\begin{tabular}{|c|c|c|c|c|c|c|c|c|c|c|c|c|}
\hline kWh & Jan & Feb & Mar & Apr & May & Jun & Jul & Aug & Sept & Oct & Nov & Dec \\
\hline B & & & & & & & & & & & & \\
\hline Electricity & 280 & 310 & 360 & 390 & 420 & 430 & 440 & 440 & 420 & 340 & 180 & 200 \\
\hline Lighting & 158.2 & 135.3 & 118.3 & 79.31 & 75.93 & 49.96 & 56.07 & 61.54 & 75.73 & 139.6 & 185.2 & 180.6 \\
\hline Com & 365.6 & 405.1 & 425.4 & 474.1 & 531.4 & 462.1 & 531.4 & 508.3 & 439.6 & 465.9 & 425.4 & 324.1 \\
\hline
\end{tabular}

In this case also, the result shows that BIPV can easily generate electricity to fulfill the lighting energy throughout the year. It also shows that BIPV can fulfill above $70 \%$ the combined (lighting + computers) energy demand of the office from April to September. During the rest of the months, the BIPV can fulfill more than $50 \%$ of the combined demand except for November and December where it meets $30 \%$ and $40 \%$ of the demand.

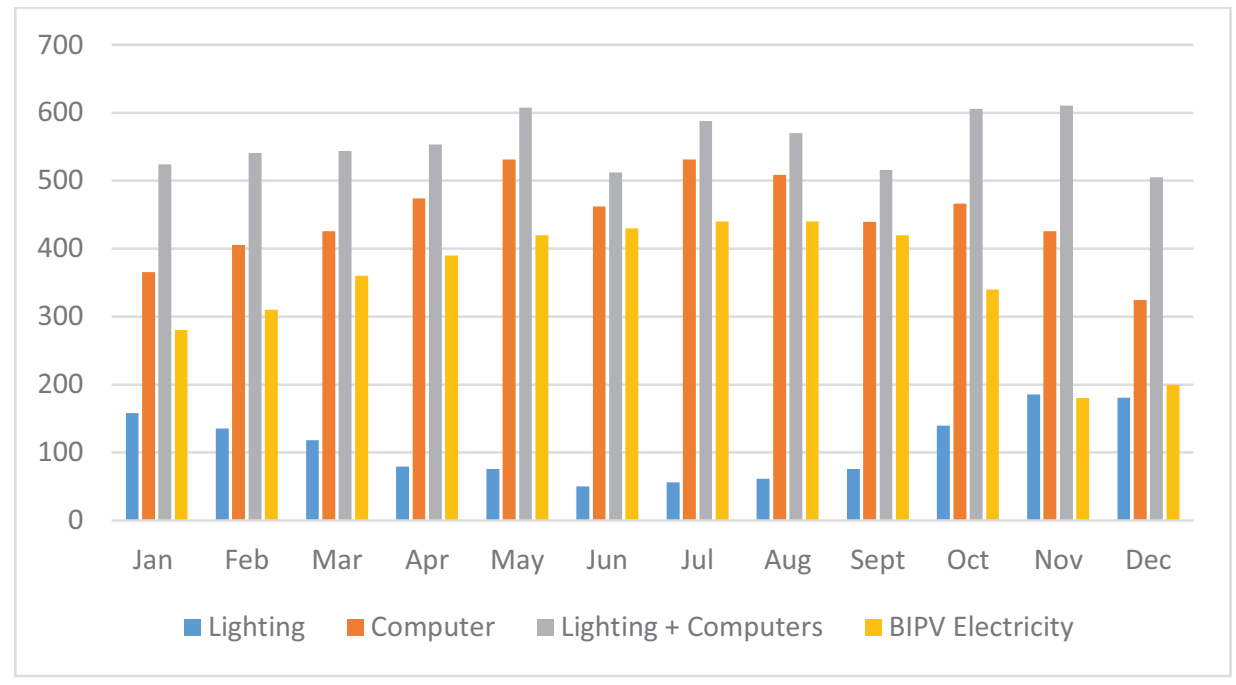

Fig 33: Case 5 BIPV vs Monthly electricity demand (kWh) 


\section{Cost analysis}

The building's heating system was a natural gas whereas the lighting, cooling systems were electricity. It was important to analyse the cost impact of BIPV application. So the heating, cooling and lighting energy demand were summarized based the results of all 5 different Cases of BIPV application against the base model. So, the results were categorized based on the source of energy.

\subsection{Natural Gas for space heating}

The total annual heating demand in all the cases were taken into account to compare against the Base Model. It can be seen in the table 19 that the Case 3 (BIPV on the lower half of South windows) has the least amount of annual natural gas consumption for space heating. The highest demand for the space heating demand can be seen in Case 1. But still, there is not a substantial difference between among Case 2, Case 4 and Case 5.

Table 20: Annual natural gas and the costs

\begin{tabular}{c|c|c}
\hline & Annual Natural Gas (kWh) & Annual Cost (\$) \\
\hline Base Model & 21737.78 & 410.74 \\
\hline Case 1 & 24836.47 & 469.29 \\
\hline Case 2 & 22956.37 & 433.77 \\
\hline Case 3 & 22393.08 & 423.12 \\
\hline Case 4 & 23536.21 & 444.72 \\
\hline Case 5 & 23429.88 & 442.71 \\
\hline
\end{tabular}

The results shows that in all the cases, that the space heating demand increases due to BIPV application. However, the maximum increment is $15 \%$ (Case 1) and the corresponding cost is roughly 60 dollars higher annually. Similarly, the least is $3 \%$ in Case 3 which is around 13 dollars increment annually. From the economical 
perspective, there is not a major difference in the space heating cost. The cost per meter cube of natural gas is calculated with reference to Natural Resource Gas Limited [23] and the unit conversion (from kWh to cubic meter) was done using Energy Conversion Calculator [24].

\subsection{Electricity for lighting and space cooling}

Similarly, the electricity consumption for space cooling and lighting is another important factor. It is because the cost of electricity compared to natural gas is expensive in Toronto and the summer months are typically hot and humid which adds load to the cooling system. The calculation of unit price of electricity was taken with reference to Hydro One website. It has summer rate (May - October) and winter rate (November - April). According the website, the unit prices are different during peakhour, mid-peak and off-peak hours (both during summer and winter rates). However, in our case, the mode of occupancy in mostly during the daytime. So, the unit rate of per kWh has been included in the calculation accordingly.

Table 21 shows the monthly and annual energy demand with cost for lighting, cooling and computer use for the faculty office area for the base model. The annual lighting energy demand is $1194.41 \mathrm{kWh}$ which is cost $\$ 176.50$ annually. Similarly, the annual cooling energy demand is $4565.88 \mathrm{kWh}$ that costs $\$ 821.86$ annually. The computer and equipment in the office area requires $5357.85 \mathrm{kWh}$ for its annual operation that will cost $\$ 848.31$ annually. So the space cooling demand, which is a dominant factor in this case, becomes the dominant factor. 
Table 21: Base Model-Cost of lighting, cooling and computers

\section{Base Model}

\begin{tabular}{|c|c|c|c|c|c|c|c|c|c|}
\hline Months & $\begin{array}{l}\text { Lighting } \\
\text { kWh }\end{array}$ & $\begin{array}{l}\text { Rate } \\
\mathbf{k W h} \mathbf{h}^{\star}\end{array}$ & $\begin{array}{l}\text { Lighting } \\
\text { Cost (\$) }\end{array}$ & $\begin{array}{l}\text { Cooling } \\
\text { kWh }\end{array}$ & $\begin{array}{l}\text { Rate } \\
\mathbf{k W h} \mathbf{h}^{*}\end{array}$ & $\begin{array}{l}\text { Cooling } \\
\text { Cost (\$) }\end{array}$ & $\begin{array}{c}\text { Computer } \\
\text { s }\end{array}$ & $\begin{array}{l}\text { Rate } \\
\mathbf{k W h}^{*}\end{array}$ & $\begin{array}{c}\text { Computer } \\
\text { s } \\
\text { Cost (\$) } \\
\end{array}$ \\
\hline Jan & 147.59 & 13.20 & 19.48 & 0.00 & 13.20 & 0.00 & 364.64 & 13.20 & 48.13 \\
\hline Feb & 129.28 & 13.20 & 17.06 & 0.00 & 13.20 & 0.00 & 405.15 & 13.20 & 53.48 \\
\hline March & 109.37 & 13.20 & 14.44 & 0.00 & 13.20 & 0.00 & 425.41 & 13.20 & 56.15 \\
\hline Apr & 70.71 & 13.20 & 9.33 & 0.00 & 13.20 & 0.00 & 474.16 & 13.20 & 62.59 \\
\hline May & 67.16 & 18.00 & 12.09 & 743.53 & 18.00 & 133.84 & 531.45 & 18.00 & 95.66 \\
\hline Jun & 38.31 & 18.00 & 6.90 & 1927.09 & 18.00 & 346.88 & 462.13 & 18.00 & 83.18 \\
\hline Jul & 47.49 & 18.00 & 8.55 & 1430.55 & 18.00 & 257.50 & 531.45 & 18.00 & 95.66 \\
\hline Aug & 53.90 & 18.00 & 9.70 & 436.32 & 18.00 & 78.54 & 508.34 & 18.00 & 91.50 \\
\hline Sept & 67.72 & 18.00 & 12.19 & 28.39 & 18.00 & 5.11 & 439.66 & 18.00 & 79.14 \\
\hline Oct & 117.93 & 18.00 & 21.23 & 0.00 & 18.00 & 0.00 & 465.93 & 18.00 & 83.87 \\
\hline Nov & 175.17 & 13.20 & 23.12 & 0.00 & 13.20 & 0.00 & 425.41 & 13.20 & 56.15 \\
\hline Dec & 169.78 & 13.20 & 22.41 & 0.00 & 13.20 & 0.00 & 324.12 & 13.20 & 42.78 \\
\hline Total & 1194.41 & & 176.50 & 4565.88 & & 821.86 & 5357.85 & & 848.31 \\
\hline
\end{tabular}

Table 22 shows that the annual and monthly lighting and cooling energy demand and the respective operation cost calculation of Case 1 (Full BIPV application on South and West). The calculation shows the annual lighting demand is $1424.89 \mathrm{kWh}$ which costs $\$ 211.07$. Compared to base model, the cost is almost $20 \%$ higher. On the other side, the annual cooling demand is $3428.81 \mathrm{kWh}$ and the related operation cost is $\$ 617.19$. Compared to base model, the cooling energy demand is less by $25 \%$. Additionally, the BIPV annual electricity generation of BIPV is $8030 \mathrm{kWh}$ and the calculated revenue of $\$ 1287.48$. During July and August, the cooling demand is very high yet the power and revenue generated by BIPV can cover about $50 \%$ of lighting and cooling cost. Whereas in the remaining months, the monthly expenses for lighting and cooling are less than the revenue generated by BIPV. 
Table 22: Case1-Cost of lighting, cooling and computers vs BIPV Revenue

Case 1

\begin{tabular}{|c|c|c|c|c|c|c|c|c|c|}
\hline Months & $\begin{array}{l}\text { Lighting } \\
\text { kWh }\end{array}$ & $\begin{array}{l}\text { Rate } \\
\text { kWh }^{*}\end{array}$ & $\begin{array}{l}\text { Monthly } \\
\text { Lighting } \\
\text { Cost (\$) }\end{array}$ & $\begin{array}{l}\text { Cooling } \\
\text { kWh }\end{array}$ & $\begin{array}{l}\text { Rate } \\
\text { kWh }\end{array}$ & $\begin{array}{l}\text { Monthly } \\
\text { Cooling } \\
\text { Cost (\$) }\end{array}$ & $\begin{array}{c}\text { BIPV } \\
\text { eletricity }\end{array}$ & $\begin{array}{l}\text { Rate } \\
\text { kWh }\end{array}$ & $\begin{array}{l}\text { Monthly } \\
\text { BIPV } \\
\text { eletricity } \\
\text { value (\$) }\end{array}$ \\
\hline Jan & 175.40 & 13.20 & 23.15 & 0.00 & 13.20 & 0.00 & 530.00 & 13.20 & 69.96 \\
\hline Feb & 160.10 & 13.20 & 21.13 & 0.00 & 13.20 & 0.00 & 590.00 & 13.20 & 77.88 \\
\hline March & 122.20 & 13.20 & 16.13 & 0.00 & 13.20 & 0.00 & 690.00 & 13.20 & 91.08 \\
\hline Apr & 87.90 & 13.20 & 11.60 & 0.00 & 13.20 & 0.00 & 750.00 & 13.20 & 99.00 \\
\hline May & 82.00 & 18.00 & 14.76 & 0.00 & 18.00 & 0.00 & 790.00 & 18.00 & 142.20 \\
\hline Jun & 51.49 & 18.00 & 9.27 & 518.33 & 18.00 & 93.30 & 810.00 & 18.00 & 145.80 \\
\hline Jul & 59.10 & 18.00 & 10.64 & 1513.19 & 18.00 & 272.37 & 850.00 & 18.00 & 153.00 \\
\hline Aug & 63.00 & 18.00 & 11.34 & 1079.86 & 18.00 & 194.37 & 840.00 & 18.00 & 151.20 \\
\hline Sept & 82.00 & 18.00 & 14.76 & 317.43 & 18.00 & 57.14 & 800.00 & 18.00 & 144.00 \\
\hline Oct & 141.20 & 18.00 & 25.42 & 0.00 & 18.00 & 0.00 & 650.00 & 18.00 & 117.00 \\
\hline Nov & 206.00 & 13.20 & 27.19 & 0.00 & 13.20 & 0.00 & 350.00 & 13.20 & 46.20 \\
\hline Dec & 194.50 & 13.20 & 25.67 & 0.00 & 13.20 & 0.00 & 380.00 & 13.20 & 50.16 \\
\hline Total & 1424.89 & & 211.07 & 3428.81 & & 617.19 & 8030.00 & & 1287.48 \\
\hline
\end{tabular}

The table 23 shows that the annual and monthly lighting and cooling energy demand and the respective operation cost calculation of Case 2 (BIPV on the West Window only). It shows the annual lighting demand is $1337.26 \mathrm{kWh}$ which costs $\$ 197.78$. Compared to base model, the cost is almost $12 \%$ higher. On the other side, the annual cooling demand is $3791.45 \mathrm{kWh}$ and the related operation cost is $\$ 682.46$. Compared to base model, the cooling energy demand cost is less by $17 \%$. Additionally, the BIPV annual electricity generation of BIPV is $4340 \mathrm{kWh}$ and the calculated revenue of \$703.92. During July, the cooling demand is the highest and revenue generated by BIPV can cover about $30 \%$ of lighting and cooling cost. Similarly in August, it can fulfill around $40 \%$ of the demand (lighting + cooling). In November-December though the electricity production is very low and the space cooling is not required, BIPV fulfills more that $82 \%$ of the demand. 
Table 23: Case 2-Cost of lighting, cooling and computers vs BIPV Revenue

Case 2

\begin{tabular}{|c|c|c|c|c|c|c|c|c|c|}
\hline Months & $\begin{array}{c}\text { Lighting } \\
\text { kWh }\end{array}$ & $\begin{array}{l}\text { Rate } \\
\mathbf{k W h}^{*}\end{array}$ & $\begin{array}{l}\text { Monthly } \\
\text { Lighting } \\
\text { Cost (\$) }\end{array}$ & $\begin{array}{c}\text { Cooling } \\
\text { kWh }\end{array}$ & $\begin{array}{l}\text { Rate } \\
\mathbf{k W h}^{*}\end{array}$ & $\begin{array}{l}\text { Monthly } \\
\text { Cooling } \\
\text { Cost (\$) }\end{array}$ & $\begin{array}{c}\text { BIPV } \\
\text { eletricity }\end{array}$ & $\begin{array}{l}\text { Rate } \\
\mathbf{k W h}^{\star}\end{array}$ & $\begin{array}{l}\text { Monthly } \\
\text { BIPV } \\
\text { eletricity } \\
\text { value (\$) }\end{array}$ \\
\hline Jan & 162.00 & 13.20 & 21.38 & 0.00 & 13.20 & 0.00 & 240.00 & 13.20 & 31.68 \\
\hline Feb & 135.70 & 13.20 & 17.91 & 0.00 & 13.20 & 0.00 & 290.00 & 13.20 & 38.28 \\
\hline March & 128.00 & 13.20 & 16.90 & 0.00 & 13.20 & 0.00 & 340.00 & 13.20 & 44.88 \\
\hline Apr & 87.20 & 13.20 & 11.51 & 0.00 & 13.20 & 0.00 & 420.00 & 13.20 & 55.44 \\
\hline May & 72.88 & 18.00 & 13.12 & 0.00 & 18.00 & 0.00 & 470.00 & 18.00 & 84.60 \\
\hline Jun & 51.68 & 18.00 & 9.30 & 584.71 & 18.00 & 105.25 & 510.00 & 18.00 & 91.80 \\
\hline Jul & 49.78 & 18.00 & 8.96 & 1635.78 & 18.00 & 294.44 & 520.00 & 18.00 & 93.60 \\
\hline Aug & 57.53 & 18.00 & 10.36 & 1208.74 & 18.00 & 217.57 & 500.00 & 18.00 & 90.00 \\
\hline Sept & 72.89 & 18.00 & 13.12 & 362.22 & 18.00 & 65.20 & 410.00 & 18.00 & 73.80 \\
\hline Oct & 138.10 & 18.00 & 24.86 & 0.00 & 18.00 & 0.00 & 320.00 & 18.00 & 57.60 \\
\hline Nov & 194.60 & 13.20 & 25.69 & 0.00 & 13.20 & 0.00 & 160.00 & 13.20 & 21.12 \\
\hline Dec & 186.90 & 13.20 & 24.67 & 0.00 & 13.20 & 0.00 & 160.00 & 13.20 & 21.12 \\
\hline Total & 1337.26 & & 197.78 & 3791.45 & & 682.46 & 4340.00 & & 703.92 \\
\hline
\end{tabular}

The table 24 shows that the annual and monthly lighting and cooling energy demand and the respective operation cost calculation of Case 3 (BIPV on the lower half of West Window only). It shows the annual lighting demand is $1296.61 \mathrm{kWh}$ which costs $\$ 192.27$. Compared to base model, the cost is almost $9 \%$ higher. On the other side, the annual cooling demand is $4140.14 \mathrm{kWh}$ with annual costing of $\$ 745.23$. Compared to base model, the cooling energy demand cost is less by $10 \%$. Additionally, the BIPV annual electricity generation of BIPV is $2310 \mathrm{kWh}$ and the calculated revenue of $\$ 374.52$. In this case also, the annual lighting cost is less than the revenue generated by BIPV. During November and December, the lighting demand is higher while the BIPV power generation is at lower end. So, the BIPV fulfills around $50 \%$ of the lighting demand during this period. Whereas, the lighting demand is less from June to August and the cooling demand as well as BIPV power generation is higher. BIPV can fulfill $15 \%-45 \%$ of the combined (lighting and cooling) during this period as well. 
Table 24: Case 3- Cost of lighting, cooling and computers vs BIPV Revenue

Case 3

\begin{tabular}{c|c|c|c|c|c|c|c|c|c}
\hline Months & $\begin{array}{c}\text { Lighting } \\
\text { kWh }\end{array}$ & $\begin{array}{c}\text { Rate } \\
\text { kWh }\end{array}$ & $\begin{array}{c}\text { Monthly } \\
\text { Lighting } \\
\text { Cost } \mathbf{( \$ )}\end{array}$ & $\begin{array}{c}\text { Cooling } \\
\text { kWh }\end{array}$ & $\begin{array}{c}\text { Rate } \\
\text { kWh }\end{array}$ & $\begin{array}{c}\text { Monthly } \\
\text { Cooling } \\
\text { Cost } \mathbf{( \$ )}\end{array}$ & $\begin{array}{c}\text { BIPV } \\
\text { eletricity }\end{array}$ & $\begin{array}{c}\text { Rate } \\
\text { kWh }\end{array}$ & $\begin{array}{c}\text { Monthly } \\
\text { BIPV } \\
\text { eletricity } \\
\text { value (\$) }\end{array}$ \\
\hline Jan & 156.45 & 13.20 & 20.65 & 0.00 & 13.20 & 0.00 & 130.00 & 13.20 & 17.16 \\
\hline Feb & 140.09 & 13.20 & 18.49 & 0.00 & 13.20 & 0.00 & 160.00 & 13.20 & 21.12 \\
\hline March & 118.60 & 13.20 & 15.66 & 0.00 & 13.20 & 0.00 & 180.00 & 13.20 & 23.76 \\
\hline Apr & 78.02 & 13.20 & 10.30 & 0.00 & 13.20 & 0.00 & 220.00 & 13.20 & 29.04 \\
\hline May & 75.39 & 18.00 & 13.57 & 0.00 & 18.00 & 0.00 & 250.00 & 18.00 & 45.00 \\
\hline Jun & 44.78 & 18.00 & 8.06 & 663.09 & 18.00 & 119.36 & 270.00 & 18.00 & 48.60 \\
\hline Jul & 56.55 & 18.00 & 10.18 & 1768.74 & 18.00 & 318.37 & 280.00 & 18.00 & 50.40 \\
\hline Aug & 61.69 & 18.00 & 11.10 & 1313.09 & 18.00 & 236.36 & 260.00 & 18.00 & 46.80 \\
\hline Sept & 75.56 & 18.00 & 13.60 & 395.22 & 18.00 & 71.14 & 220.00 & 18.00 & 39.60 \\
\hline Oct & 125.88 & 18.00 & 22.66 & 0.00 & 18.00 & 0.00 & 170.00 & 18.00 & 30.60 \\
\hline Nov & 186.54 & 13.20 & 24.62 & 0.00 & 13.20 & 0.00 & 90.00 & 13.20 & 11.88 \\
\hline Dec & 177.06 & 13.20 & 23.37 & 0.00 & 13.20 & 0.00 & 80.00 & 13.20 & 10.56 \\
\hline Total & $\mathbf{1 2 9 6 . 6 1}$ & & $\mathbf{1 9 2 . 2 7}$ & $\mathbf{4 1 4 0 . 1 4}$ & & 745.23 & $\mathbf{2 3 1 0 . 0 0}$ & & $\mathbf{3 7 4 . 5 2}$ \\
\hline
\end{tabular}

The table 25 shows that the annual and monthly lighting and cooling energy demand and the respective operation cost calculation of Case 4 (BIPV + low-E on the South and West). The annual lighting demand is $1547.29 \mathrm{kWh}$ with the respective cost $\$ 228.37$. Compared to base model, the cost is almost $30 \%$ higher. On the other side, the annual cooling demand is $3358.75 \mathrm{kWh}$ with annual costing of $\$ 604.58$. Compared to base model, the cooling energy demand cost is less by $36 \%$. Additionally, the BIPV annual electricity generation of BIPV is $8030 \mathrm{kWh}$ and the calculated revenue of \$1287.48. In this example, the BIPV power generation can easily fulfill the combined (cooling and lighting) demand except for July and August. During these two months, the cooling demand is much higher and the BIPV is capable of supplying $57 \%-80 \%$ of the need. 
Table 25: Case 4-Cost of lighting, cooling and computers vs BIPV Revenue

Case 4

\begin{tabular}{|c|c|c|c|c|c|c|c|c|c|}
\hline Months & $\begin{array}{l}\text { Lighting } \\
\text { kWh }\end{array}$ & $\begin{array}{l}\text { Rate } \\
\mathbf{k W h}^{*}\end{array}$ & $\begin{array}{l}\text { Monthly } \\
\text { Lighting } \\
\text { Cost (\$) }\end{array}$ & $\begin{array}{l}\text { Cooling } \\
\text { kWh }\end{array}$ & $\begin{array}{l}\text { Rate } \\
\mathbf{k W h}^{*}\end{array}$ & $\begin{array}{l}\text { Monthly } \\
\text { Cooling } \\
\text { Cost (\$) }\end{array}$ & $\begin{array}{c}\text { BIPV } \\
\text { eletricity }\end{array}$ & $\begin{array}{l}\text { Rate } \\
\mathbf{k W h}^{*}\end{array}$ & $\begin{array}{l}\text { Monthly } \\
\text { BIPV } \\
\text { eletricity } \\
\text { value (\$) }\end{array}$ \\
\hline Jan & 179.20 & 13.20 & 23.65 & 0.00 & 13.20 & 0.00 & 530.00 & 13.20 & 69.96 \\
\hline Feb & 163.90 & 13.20 & 21.63 & 0.00 & 13.20 & 0.00 & 590.00 & 13.20 & 77.88 \\
\hline March & 153.60 & 13.20 & 20.28 & 0.00 & 13.20 & 0.00 & 690.00 & 13.20 & 91.08 \\
\hline Apr & 91.92 & 13.20 & 12.13 & 0.00 & 13.20 & 0.00 & 750.00 & 13.20 & 99.00 \\
\hline May & 87.19 & 18.00 & 15.69 & 0.00 & 18.00 & 0.00 & 790.00 & 18.00 & 142.20 \\
\hline Jun & 53.96 & 18.00 & 9.71 & 504.74 & 18.00 & 90.85 & 810.00 & 18.00 & 145.80 \\
\hline Jul & 62.17 & 18.00 & 11.19 & 1481.86 & 18.00 & 266.73 & 850.00 & 18.00 & 153.00 \\
\hline Aug & 67.08 & 18.00 & 12.07 & 1059.31 & 18.00 & 190.68 & 840.00 & 18.00 & 151.20 \\
\hline Sept & 86.79 & 18.00 & 15.62 & 312.84 & 18.00 & 56.31 & 800.00 & 18.00 & 144.00 \\
\hline Oct & 145.50 & 18.00 & 26.19 & 0.00 & 18.00 & 0.00 & 650.00 & 18.00 & 117.00 \\
\hline Nov & 225.16 & 13.20 & 29.72 & 0.00 & 13.20 & 0.00 & 350.00 & 13.20 & 46.20 \\
\hline Dec & 230.82 & 13.20 & 30.47 & 0.00 & 13.20 & 0.00 & 380.00 & 13.20 & 50.16 \\
\hline Total & 1547.29 & & 228.37 & 3358.75 & & 604.58 & 8030.00 & & 1287.48 \\
\hline
\end{tabular}

The table 26 shows that the annual and monthly lighting and cooling energy demand and the respective operation cost calculation of Case 5 (BIPV -lower half of South and West). The annual lighting demand is $1315.74 \mathrm{kWh}$ with the respective cost $\$ 195.70$. Compared to base model, the lighting cost is almost $10 \%$ higher. Similarly, the annual cooling demand is $3903.50 \mathrm{kWh}$ with annual costing of $\$ 702.63$. When compared to base model, the cooling energy demand cost is less by $17 \%$. Additionally, the BIPV annual electricity generation of BIPV is $4210 \mathrm{kWh}$ and the calculated revenue of $\$ 675.24$. In this example also, the BIPV power generation can easily fulfill combined (cooling and lighting) demand except from June to August. During these three months, the cooling demand is much higher and the BIPV is capable of supplying $25 \%-65 \%$ of the combined (lighting and cooling) need. 
Table 26: Case5-Cost of lighting, cooling and computers + BIPV Revenue

Case 5

\begin{tabular}{c|c|c|c|c|c|c|c|c|c}
\hline Months & $\begin{array}{c}\text { Lighting } \\
\text { kWh }\end{array}$ & $\begin{array}{c}\text { Rate } \\
\text { kWh }\end{array}$ & $\begin{array}{c}\text { Monthly } \\
\text { Lighting } \\
\text { Cost } \mathbf{( \$ )}\end{array}$ & $\begin{array}{c}\text { Cooling } \\
\mathbf{k W h}\end{array}$ & $\begin{array}{c}\text { Rate } \\
\text { kWh }\end{array}$ & $\begin{array}{c}\text { Monthly } \\
\text { Cooling } \\
\text { Cost } \mathbf{( \$ )}\end{array}$ & $\begin{array}{c}\text { BIPV } \\
\text { eletricity }\end{array}$ & $\begin{array}{c}\text { Rate } \\
\text { kWh } \mathbf{h}^{\star}\end{array}$ & $\begin{array}{c}\text { Monthly } \\
\text { BIPV } \\
\text { eletricity } \\
\text { value (\$) }\end{array}$ \\
\hline Jan & 158.20 & 13.20 & 20.88 & 0.00 & 13.20 & 0.00 & 280.00 & 13.20 & 36.96 \\
\hline Feb & 135.30 & 13.20 & 17.86 & 0.00 & 13.20 & 0.00 & 310.00 & 13.20 & 40.92 \\
\hline March & 118.30 & 13.20 & 15.62 & 0.00 & 13.20 & 0.00 & 360.00 & 13.20 & 47.52 \\
\hline Apr & 79.31 & 13.20 & 10.47 & 0.00 & 13.20 & 0.00 & 390.00 & 13.20 & 51.48 \\
\hline May & 75.93 & 18.00 & 13.67 & 0.00 & 18.00 & 0.00 & 420.00 & 18.00 & 75.60 \\
\hline Jun & 49.96 & 18.00 & 8.99 & 621.61 & 18.00 & 111.89 & 430.00 & 18.00 & 77.40 \\
\hline Jul & 56.07 & 18.00 & 10.09 & 1691.24 & 18.00 & 304.42 & 440.00 & 18.00 & 79.20 \\
\hline Aug & 61.54 & 18.00 & 11.08 & 1230.42 & 18.00 & 221.48 & 440.00 & 18.00 & 79.20 \\
\hline Sept & 75.73 & 18.00 & 13.63 & 360.23 & 18.00 & 64.84 & 420.00 & 18.00 & 75.60 \\
\hline Oct & 139.60 & 18.00 & 25.13 & 0.00 & 18.00 & 0.00 & 340.00 & 18.00 & 61.20 \\
\hline Nov & 185.20 & 13.20 & 24.45 & 0.00 & 13.20 & 0.00 & 180.00 & 13.20 & 23.76 \\
\hline Dec & 180.60 & 13.20 & 23.84 & 0.00 & 13.20 & 0.00 & 200.00 & 13.20 & 26.40 \\
\hline Total & $\mathbf{1 3 1 5 . 7 4}$ & & $\mathbf{1 9 5 . 7 0}$ & 3903.50 & & 702.63 & $\mathbf{4 2 1 0 . 0 0}$ & & $\mathbf{6 7 5 . 2 4}$ \\
\hline
\end{tabular}

Table 27 shows the cost summary of the annual energy cost for lighting, cooling, lighting + cooling (combined) and the capacity of BIPV revenue generation in each case. It can be observed that Case $1 \& 4$ generates the highest revenue annually followed by Case 2 and Case 5 while the Case 3 generates the least of all.

Table 27: Summary of Annual Energy Cost Vs BIPV Revenue (\$)

\begin{tabular}{c|c|c|c|c}
\hline \multicolumn{5}{|c}{ Summary of Annual Energy Cost Vs BIPV Revenue (\$) } \\
\hline & Lighting & Cooling & Cooling + Lighting & BIVP Revenue \\
\hline Base Model & 176.50 & 821.86 & 998.36 & 0.00 \\
\hline Case 1 & 211.07 & 617.19 & 828.25 & 1287.48 \\
\hline Case 2 & 197.78 & 682.46 & 880.24 & 703.92 \\
\hline Case 3 & 192.27 & 745.23 & 937.49 & 374.52 \\
\hline Case 4 & 228.37 & 604.58 & 832.95 & 1287.48 \\
\hline Case 5 & 195.70 & 702.63 & 898.33 & 675.24 \\
\hline
\end{tabular}


Figure 34 is a summary of the cost of lighting, cooling, BIPV and combined cost (cooling + lighting). Compared to the clear glass (Base model), the lighting energy increase with the BIPV application. However, the cooling energy demand decreases. In Case 1 and Case 4, the BIPV generated more electricity to compensate the combined electricity value of cooling and lighting. In Case 2 and Case 5, the BIPV covers around $70 \%$ and $80 \%$ of the cost respectively. The least, $45 \%$, is achieved in Case 3.

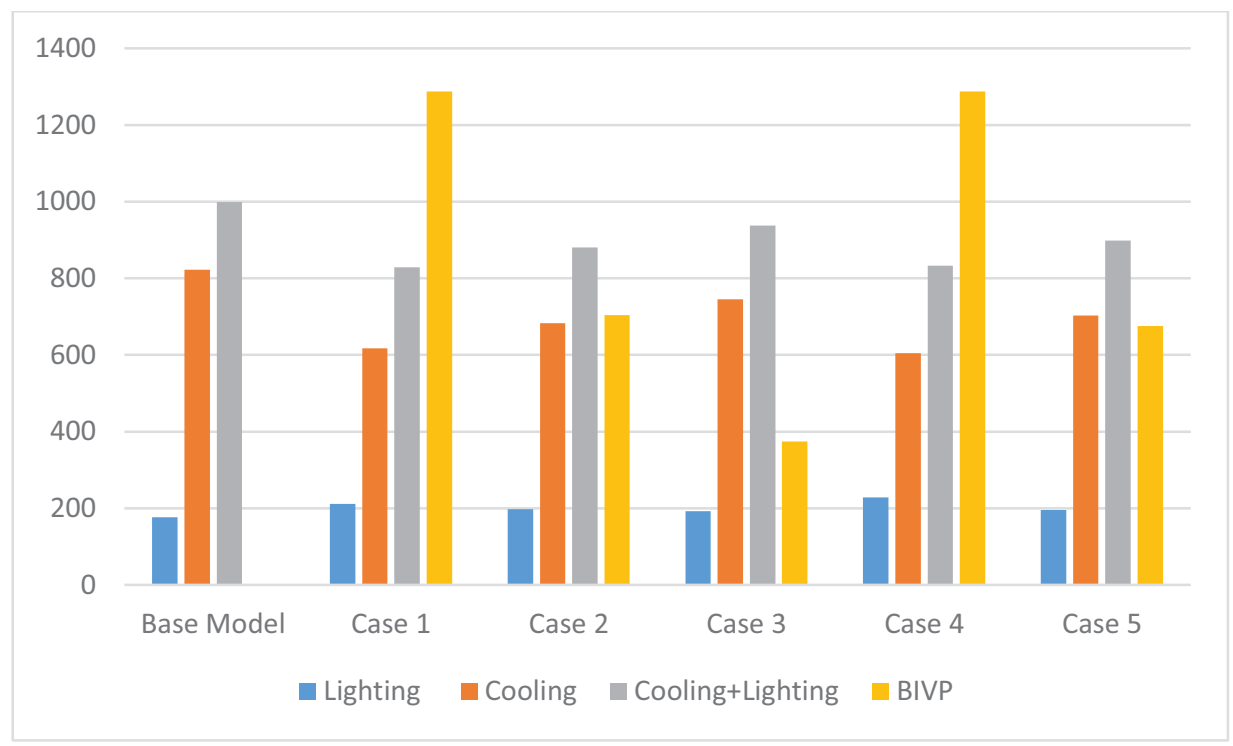

Fig 34: Annual cost of electricity for cooling and lighting vs BIPV (pricing in dollars)

\subsection{Payback Calculation:}

The BIPV cost estimate is still under development. Mass manufacturing of the BIPV has not yet taken place because the requirement for each project can be different than the other. There are many factors like special need, design parameters and technical aspects which needs a detail work out that contributes to cost variations. However the cost of the BIPV window can range from $\$ 60 / \mathrm{ft}^{2}-\$ 120 / \mathrm{ft}^{2}$. The cost was provided by Livio Nichilo, Engineering Manager, Internat Energy Solutions Canada Inc, based on 
an e-mail communication. He further added that the cost needs to be around $\$ 30 / \mathrm{ft}^{2}$ in order to take off successfully. While calculating the payback period, cost of BIPV has been considered $\$ 75 / \mathrm{ft}^{2}$ (average of recommended $\$ 60 / \mathrm{ft}^{2}-\$ 120 / \mathrm{ft}^{2}$ ).

While estimating the cost of BIPV, it is also important to remember that the BIPV fulfills the dual purpose, replaces window and generates electricity. The cost of window needs to be deducted from the total cost of BIPV. The cost difference can be regarded as the actual cost of BIPV application. So, in this case, the cost of window was calculated to $\$ 62.5 /$ sq. $\mathrm{ft}^{2}$. [25]

Table 28: Cost calculation of BIPV (\$)

\begin{tabular}{|c|c|c|c|c|c|c|}
\hline \multicolumn{7}{|c|}{ Cost Calculation of BIPV } \\
\hline & $\begin{array}{l}\text { Window } \\
\text { size }\left(\mathrm{ft}^{2}\right)\end{array}$ & $\begin{array}{l}\text { Rate/ } \mathrm{ft}^{2} \\
\text { (\$) }\end{array}$ & $\begin{array}{l}\text { Total cost } \\
\text { (\$) }\end{array}$ & $\begin{array}{c}\text { Window } \\
\text { Cost } / \mathrm{ft}^{2}(\$)\end{array}$ & $\begin{array}{c}\text { BIPV } \\
\text { Cost } / \mathrm{ft}^{2}(\$)\end{array}$ & $\begin{array}{c}\text { Actual BIPV } \\
\text { cost (\$) }\end{array}$ \\
\hline Case 1 & 865.55 & 75.00 & 64916.25 & 62.50 & 12.50 & 10819.38 \\
\hline Case 2 & 492.07 & 75.00 & 36905.25 & 62.50 & 12.50 & 6150.88 \\
\hline Case 3 & 246.04 & 75.00 & 18452.82 & 62.50 & 12.50 & 3075.47 \\
\hline Case 4 & 865.55 & 75.00 & 64916.25 & 62.50 & 12.50 & 10819.38 \\
\hline Case 5 & 432.77 & 75.00 & 32457.75 & 62.50 & 12.50 & 5409.63 \\
\hline
\end{tabular}

Table 27 shows the cost calculation of the BIPV. If the overall cost (including window cost) is included as the initial cost of BIPV, the payback period, in all the cases, is going to be extremely high. None of the options seem to be attractive from the financial investment perspective. However, is important to remember that the BIPV replaces the window and the cost of window needs to be discounted while calculating the actual cost of BIPV and the related payback period. In this case, the cost of window is calculated to be $\$ 62.5 / \mathrm{ft}^{2}$ and the remaining $\$ 12.5 / \mathrm{ft}^{2}$ is the actual cost of BIPV. Based 
on this analysis, the discounted payback period for BIPV was calculated. The result shows that the payback period is in between 11 to 13 years.

The payback period was calculated using equation 1 , which includes the discounted payback period (DPP) with $5 \%$ interest rate $(r)$. The cash flow (CF) is equivalent to the BIPV revenue generation in each case from Table 27. The initial investment (Q1) is the actual BIPV cost in each case from Table 28. Based on the summary of the calculation, the payback period of BIPV is between 11 to 13 years. The lowest discounted payback period is for Case 3 where the highest payback period is for Case 1 and Case 4.

$D P P=\ln \left(\frac{1}{1-\frac{Q 1 * r}{C F}}\right) \div \ln (1+r)$ Equation:1 [26]

Table 29 includes the summary of discounted payback period for Case 1, Case 2 and Case 4. The cash flow (CF) which is equivalent to the revenue generated by BIPV in Case 1 and Case 4 will be the same amount because the BIPV application in these cases are same. The calculation shows that with $5 \%$ interest rate and annual cash flow of $\$ 1287.48$, it will take 12.83 years to pay the initial investment (Q1) $\$ 10819.00$. Similarly, in Case 2 the BIPV application is only towards the south windows. The initial investment cost calculated (Q1) for this window is $\$ 6150$ and the annual revenue (CF) of $\mathrm{BIPV}$ is $\$ 703.62$. With $5 \%$ interest rate, the calculated payback period is 12.22 years. Compared to Case 1 and Case 4, the initial investment and the cash flow of Case 2 is almost $50 \%$ less, but the payback period is even lesser. However, the level of comfort (visual, heating and cooling) also need to be considered rather that evaluating the financial aspect only. 
Table 29: Discounted Pay Back Period for Case 1, 2 and 4

\begin{tabular}{c|c|c|c}
\hline \multicolumn{4}{|c}{ Case 1 \& 4: Discounted Pay Back } \\
\hline Years & $\begin{array}{c}\text { Cash Flow } \\
\text { (CF) }\end{array}$ & $\begin{array}{c}\text { Q1 } \\
\text { (Present } \\
\text { Value) }\end{array}$ & Balance \\
\hline 0 & -10819.00 & -10819.00 & -10819.00 \\
\hline 1 & 1287.48 & 1226.17 & -9592.83 \\
\hline 2 & 1287.48 & 1167.78 & -8425.05 \\
\hline 3 & 1287.48 & 1112.17 & -7312.87 \\
\hline 4 & 1287.48 & 1059.21 & -6253.66 \\
\hline 5 & 1287.48 & 1008.77 & -5244.89 \\
\hline 6 & 1287.48 & 960.74 & -4284.15 \\
\hline 7 & 1287.48 & 914.99 & -3369.16 \\
\hline 8 & 1287.48 & 871.42 & -2497.74 \\
\hline 9 & 1287.48 & 829.92 & -1667.82 \\
\hline 10 & 1287.48 & 790.40 & -877.42 \\
\hline 11 & 1287.48 & 752.76 & -124.66 \\
\hline 12 & 1287.48 & 716.92 & 592.26 \\
\hline Discounted Payback Period & 12.83 \\
\hline & & &
\end{tabular}

\begin{tabular}{c|c|c|c}
\hline \multicolumn{4}{|c}{ Case 2: Discounted Pay Back } \\
\hline Years & $\begin{array}{c}\text { Cash Flow } \\
\text { (CF) }\end{array}$ & $\begin{array}{c}\text { Q1 } \\
\text { (Present } \\
\text { Value) }\end{array}$ & Balance \\
\hline 0 & -6150.88 & -6150.88 & -6150.88 \\
\hline 1 & 703.92 & 670.40 & -5480.48 \\
\hline 2 & 703.92 & 638.48 & -4842.00 \\
\hline 3 & 703.92 & 608.07 & -4233.93 \\
\hline 4 & 703.92 & 579.12 & -3654.81 \\
\hline 5 & 703.92 & 551.54 & -3103.27 \\
\hline 6 & 703.92 & 525.28 & -2578.00 \\
\hline 7 & 703.92 & 500.26 & -2077.74 \\
\hline 8 & 703.92 & 476.44 & -1601.30 \\
\hline 9 & 703.92 & 453.75 & -1147.54 \\
\hline 10 & 703.92 & 432.15 & -715.40 \\
\hline 11 & 703.92 & 411.57 & -303.83 \\
\hline 12 & 703.92 & 391.97 & 88.14 \\
\hline Discounted Payback Period & 12.22 \\
\hline & & &
\end{tabular}

Table 30 includes the summary of discounted payback period for Case 3 and Case

5. The cash flow (CF) which is equivalent to the annual revenue generated by BIPV in Case 3 is $\$ 374.52$ because in this case, the BIPV is applied on the lower half of west windows. The initial investment is $\$ 3075.47$ and the calculated payback period is 11.17 years. Case 3 has the lowest payback period among all other cases. Similarly, in Case 5, the BIPV is applied on the lower half of South and West windows. With the initial investment $\$ 5409.63$ and the annual cash flow $\$ 675.24$ the payback period is 11.5 years. Compared to Case 3 , Case 5 has higher initial investment cost but the payback period is almost the same. Due to the higher revenue generated by BIPV Case 5, the payback period became less. 
Table 30: Discounted Pay Back Period for Case 3 and 5

\begin{tabular}{c|c|c|c}
\hline \multicolumn{4}{|c}{ Case 3: Discounted Pay Back } \\
\hline Years & $\begin{array}{c}\text { Cash Flow } \\
\text { (CF) }\end{array}$ & $\begin{array}{c}\text { Q1 } \\
\text { (Present } \\
\text { Value) }\end{array}$ & Balance \\
\hline 0 & -3075.47 & -3075.47 & -3075.47 \\
\hline 1 & 374.52 & 356.69 & -2718.78 \\
\hline 2 & 374.52 & 339.70 & -2379.08 \\
\hline 3 & 374.52 & 323.52 & -2055.56 \\
\hline 4 & 374.52 & 308.12 & -1747.44 \\
\hline 5 & 374.52 & 293.45 & -1453.99 \\
\hline 6 & 374.52 & 279.47 & -1174.52 \\
\hline 7 & 374.52 & 266.16 & -908.36 \\
\hline 8 & 374.52 & 253.49 & -654.87 \\
\hline 9 & 374.52 & 241.42 & -413.45 \\
\hline 10 & 374.52 & 229.92 & -183.53 \\
\hline 11 & 374.52 & 218.97 & 35.45 \\
\hline 12 & 374.52 & 208.55 & 244.00 \\
\hline Discounted Payback Period & $\mathbf{1 1 . 1 7}$ \\
\hline & & & \\
\hline
\end{tabular}

\begin{tabular}{c|c|c|c}
\hline \multicolumn{4}{|c}{ Case 5: Discounted Pay Back } \\
\hline Years & Cash Flow & $\begin{array}{c}\text { Q1 } \\
\text { (Present } \\
\text { Value) }\end{array}$ & Balance \\
\hline 0 & -5409.63 & -5409.63 & -5409.63 \\
\hline 1 & 675.24 & 643.09 & -4766.54 \\
\hline 2 & 675.24 & 612.46 & -4154.08 \\
\hline 3 & 675.24 & 583.30 & -3570.78 \\
\hline 4 & 675.24 & 555.52 & -3015.26 \\
\hline 5 & 675.24 & 529.07 & -2486.19 \\
\hline 6 & 675.24 & 503.87 & -1982.32 \\
\hline 7 & 675.24 & 479.88 & -1502.44 \\
\hline 8 & 675.24 & 457.03 & -1045.41 \\
\hline 9 & 675.24 & 435.27 & -610.14 \\
\hline 10 & 675.24 & 414.54 & -195.61 \\
\hline 11 & 675.24 & 394.80 & 199.19 \\
\hline 12 & 675.24 & 376.00 & 575.19 \\
\hline Discounted Payback Period & 11.50 \\
\hline & & & \\
\hline
\end{tabular}

The variations of BIPV implication were evident from 5 different cases compared to the existing condition, base model. The results of Case 1 and Case 4 seems attractive because of the higher electricity generation, reduction in the annual cooling energy and heat gains through windows. In both the cases, an assumption was to get rid of tree`s shadow by trimming the top parts of the tree existing trees. In reality, the City bylaws may restrict such actions. In Case 2, the BIPV application on the west side produces generous amount of annual electricity, around $50 \%$ compared to Case 1 and 4 . At the same time, the annual solar heat gain and the cooling load reduces due to BIPV on the west side. In this option the south façade continues to remain in the existing condition. 
In Case 3, the BIPV was applied only on the lower half of the west windows. In this case, the annual solar heat gains and cooling load becomes similar to the base model because of the less percentage of BIPV. However, the BIPV can still fulfill by producing more electricity than the annual lighting demand yet has the lowest payback period. The impact of BIPV on the lower half of south and west windows were analysed in Case 5 . In this case also, the annual heat gains and the cooling load demand rises and brings to the similar situation like Case 4 and base model. But the BIPV generates more than 2.5 times the annual lighting energy demand.

Ontario has the highest increase rate of hydro cost compared to all the Canadian provinces [27]. The price hiking trend does not seem to stop. Renewable energy sources like BIPV could be one of the solutions of the price escalation. Similarly, the role of BIPV in the reduction of Green House Gas emission can be substantial. However at the present condition, the BIPV is still in its developing phase. The effectiveness can only be realized when BIPV becomes an established technology. Local building codes, energy and environmental policy can play important role to create awareness, educate and produce skilled manpower. Similarly, government can adopt BIPV in pilot projects to demonstrate its performance and boost public confidence. Eventually, it can be anticipated that the BIPV becomes viable option in future due to establishment of mass production plants and also by offering varieties of options. Also the increasing hydro cost might encourage to pick BIPV as a reliable option. 


\section{Conclusion:}

The conventional perception of building as an energy consumer is shifting to building also as energy generator. Passive house design approach and zero energy building concepts also supports the fact that a building could become energy independent under certain circumstances. BIPV can also be one of the complimenting factors in the race to sustainable building practices. The primary goal of this research was to understand the impacts of BIPV in daylighting, heating, cooling and heat gains. In this study, the impact of BIPV was analysed under 5 different cases on third floor (faculty office area) of ARC building, Ryerson University. The simulation result shows the potential of BIPV application in the ARC building. The results shows that effectiveness of BIPV application in number of aspects. The heating energy demand increases due to BIPV application but the difference is not significant. However, the cooling energy demand goes down that reduces the amount of electricity required for space cooling. Consequently, there is a reduction in the annual primary energy demand. On the other hand, the application of BIPV also effectively responds to the overheating and glare by controlling the excess light. BIPV application may also allow the designers to discontinue the traditional approach of external shading devices or internal blinds for light control. Similarly, the BIPV adds value by generating electricity from a renewable source that contributes to the sustainability aspects as well. Capital investment is a very important and plays a vital role in any project. Further research to improve the cell efficiency, overall technology cost, market penetration, public awareness as well as government policy can create a promising environment for the BIPV technology. 


\section{Reference}

[1] Solar Photovoltaic Electricity Generation Available:

https://setis.ec.europa.eu/system/files/Technology Information Sheet Solar Photovolt aic.pdf

[2] International Energy Agency Available:

http://www.cansia.ca/uploads/7/2/5/1/72513707/national_survey_report_of_pv_power_2 011.pdf

[3] L. Stamenic. Developments with BIPV systems in Canada. Asian Journal of Energy Environment, 2004; 5 (4), 349-365. Available from: http://www.asian-energyjournal.info/Abstract/Developments\%20with\%20bipv\%20systems\%20in\%20canada.pdf

[4] Sophie Pelland, Yves Poissant. An evaluation of the potential of Building Integrated Photovoltaics in Canada. Renewable Energy 2006; 8

[5] Implementation and Assessment of Building Integrated Photovoltaics (BIPV) in the City of Toronto. Internat Energy Solutions Canada Inc. 2013. Available from: http://taf.ca/wp-content/uploads/2014/12/harbourfront-centre-bipv.pdf

[6] Chae, Young Tae, Kim, Jeehwan, Park, Hongsik, Shin, Byungha. Building energy performance evaluation of building integrated photovoltaic (BIPV) window with semitransparent solar cells. Applied Energy 2014; 129; 217-227.

[7] T.T. Chow, K.F. Fong, W. He, Z. Lin, A.L.S. Chan. Performance evaluation of a PV ventilated window applying to office building of Hong Kong. 2007; 39; 643-650

[8] Miyazaki, T Ã, Akisawa, A, Kashiwagi, T. Energy savings of office buildings by the use of semi-transparent solar cells for windows. Renewable Energy 2005; 30; 281-304

[9] Yoo, Seung-ho, Lee, Eun-tack. Efficiency characteristic of building integrated photovoltaics as a shading device. Building and Environment 2002; 37; 615-623

[10] Peng, Jinqing, Lu, Lin, Yang, Hongxing. ScienceDirect An experimental study of the thermal performance of a novel photovoltaic double-skin facade in Hong Kong. Solar Energy 2013; 97; 293-304

[11] C. L. Cheng, Charles S. Sanchez Jimenez, Meng Chieh Lee. Research of BIPV optimal tilted angle, use of latitude concept for south orientated plans. Renewable Energy 2009; 34 :( 6), 1644-1650

[12] Cuce, Erdem, Cuce, Pinar Mert. Tilt Angle Optimization and Passive Cooling of Building-Integrated Photovoltaics (BIPVs) for Better Electrical Performance. Arabian Journal for Science and Engineering 2014; 39: (11), 8199-8207 
[13] http://archive.iea-shc.org/publications/downloads/T41B3 approved-Jul12.pdf

[14] http://www.iea-

pvps.org/index.php?id=6\&no cache $=1 \&$ tx damfrontend pi $1 \% 5$ Bpointer $\% 5 \mathrm{D}=1$

[15] Rebecca Jing Yang, Patrick X.W Zou. Building integrated photovoltaics (BIPV) costs, benefits, risks, barriers and improvement strategy. International Journal of Construction Management 2015; 16 (1); 1-15

[16] BUILDING INTEGRATED PHOTOVOLTAICS: AN OVERVIEW OF THE EXISTING PRODUCTS AND THEIR FIELDS OF APPLICATION Strengthening the European Photovoltaic Sector. Available from:

https://www.cagbctoronto.org/files/BIPV Overview existing products.pdf

[17] https://www.klimafonds.gv.at/foerderungen/aktuellefoerderungen/2013/photovoltaik-foerderaktion/

[18] https://www.coins-global.com/services/building-integrated-photovoltaics-bipvadvanced-materials-for-construction/2383/

[19] Violeta Motuzienè, Kęstutis Valančius. Multi-criteria assessment of Building integrated Photovoltaics. Science - Future of Lithuania 2015; (7), 499-504

[20] http://www.ryerson.ca/ lixiay/campus map.pdf

[21] www.google.ca

[22] www.gaisma.com

[23]

http://www. ontarioenergyboard.ca/OEB/Consumers/Natural+Gas/Natural+Gas+Rates\#p rices

[24] http://www.abraxasenergy.com/energy-resources/toolbox/conversioncalculators/energy/)

[25] https://www.ecolinewindows.ca/pricing/

[26] http://www.financeformulas.net/Discounted-Payback-Period.html

[27] http://probeinternational.org/library/wp-content/uploads/2016/02/Getting-Zapped.pdf 